TAIANA HOMOBONO GOUVÊA

\title{
ANÁliSE ESTATÍSTICA DA INFLUÊNCIA DA PRECIPITAÇÃo E DE CARACTERÍSTICAS DO SOLO NA VARIAÇÃO DO NÍVEL D'ÁGUA EM ÁREA DE RECARGA DO AQUÍFERO GUARANI
}

Dissertação apresentada à Escola de Engenharia de São Carlos da Universidade de São Paulo como parte dos requisitos para obtenção do título de Mestre em Engenharia.

Área de Concentração: Hidráulica e Saneamento

Orientador: Edson Cezar Wendland

\section{SÃO CARLOS}


FOLHA DE JULGAMENTO

Candidata: Engenheira TAIANA HOMOBONO GOUVEA

Dissertação defendida e julgada em 07/08/2009 perante a Comissão Julgadora:

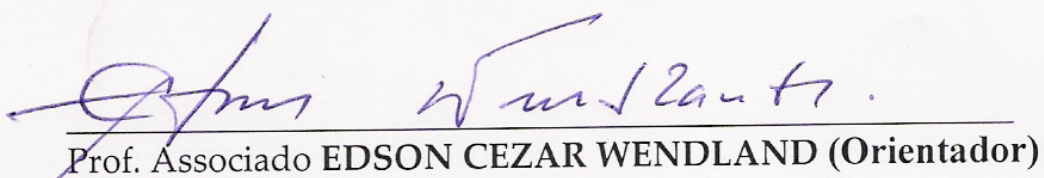

(Escola de Engenharia de São Carlos/USP)

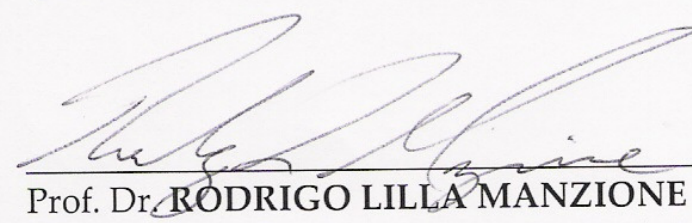

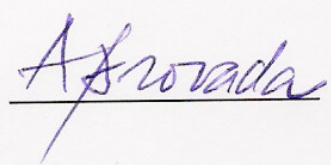

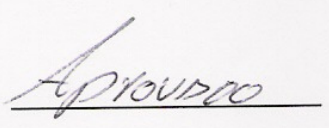

(Universidade Estadual Paulista "Julio de Mesquita Filho"/UNESP/campus de Ourinhos)

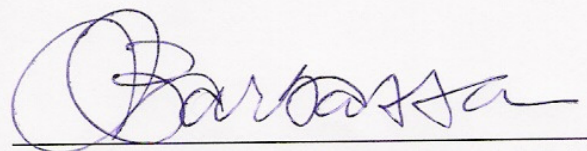

APROVABAA

Prof. Dr. ADEMIR PACELI BARBASSA

(Universidade Federal de São Carlos/UFSCar)

Prof. Associado MARCELO ZAIAT

Coordenador do Programa de Pós-Graduação em

Engenharia Hidráulica e Saneamento

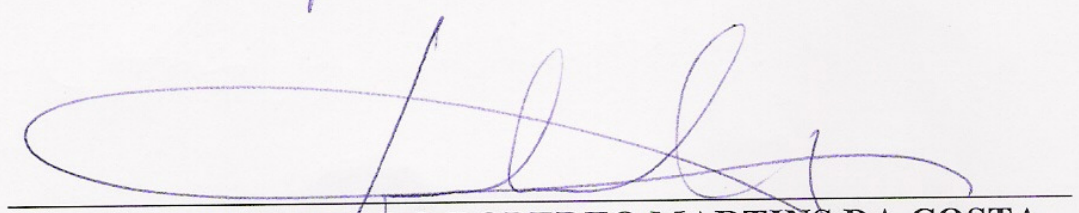

Prof. Titular GERALDO ROBERTO MARTINS DA COSTA Presidente da Comissão da Pós-Graduação da EESC 
Aos meus pilares, sem os quais eu não ficaria em pé: Orlando, Socorro e Aurélio. $A$ vocês, dedico minha esperança $e$ vontade de um mundo mais digno. 


\section{AGRADECIMENTOS}

Aos meus pais, Orlando Salgado e Socorro Homobono, meus grandes heróis. Obrigada por me permitirem sonhar e por lutarem para que cada sonho se torne realidade. E ao meu irmão Aurélio, pelo carinho e amizade de sempre, por ser a melhor parte de mim.

Aos meus avós, dignos de amor, respeito e admiração eternos.

Aos meus padrinhos: "Dinho" Jorge Teófilo e Maria José Homobono. Meus orientadores de todas as causas, os pais que meus pais escolheram para mim.

A minha tia Rosimara Lopes, que está presente em todas as etapas da minha vida.

As minhas primas, Camila, Mariella e Paulinha, motivos de risos e alegrias constantes.

As irmãs que a vida me deu, Larissa Makarem e Marília Freitas, por serem um porto seguro ao longo de todos esses anos. E aos demais amigos de Belém.

Aos amigos conquistados no mestrado, essenciais ao longo desses anos, em especial, Paulo e Maribel. E aos amigos de São Carlos, por tornarem mais aprazível minha estadia aqui: Sérgio Jungers, Cláudia Ripardo e Nathalia von Schmidt.

Ao Tauan Bernardo, "dupla" muito querida. Obrigada pela parceria e cumplicidade na fase final dessa jornada.

Aos mestres Miguel Petrere, Fazal Chaudhry e José Carlos Cintra, por serem grandes sábios e dividirem tanto conhecimento com os que têm oportunidade de com eles conviver.

Ao professor e orientador Edson C. Wendland, pelo desafio proposto, dúvidas despertadas e discussões produtivas, fundamentais ao desenvolvimento dessa pesquisa.

A equipe LHC, em especial, Fernanda Peruchi, Luiz Henrique Maldonado e Luis Henrique Gomes, e ao técnico Roberto Bergámo, pelo trabalho na fase de coleta de dados.

A CAPES (Coordenação de Aperfeiçoamento de Pessoal de Nível Superior) pela concessão da bolsa de estudos.

Ao Departamento de Hidráulica e Saneamento da Escola de Engenharia de São Carlos (EESC-USP), pela oportunidade de crescimento e aprendizado.

A todos que tornaram possível a conclusão dessa missão, à minha gratidão. Sintam-se os verdadeiros mestres. 
"Mas se Deus é as flores e as árvores E os montes e o Sol e o Luar Então acredito nele Então acredito nele a toda hora E a minha vida toda é uma oração e uma missa E uma comunhão com os olhos e pelos ouvidos" (Alberto Caeiro) 


\section{RESUMO}

GOUVÊA, T. H. Análise estatística da influência da precipitação e de características do solo na variação do nível d'água em área de recarga do Aquífero Guarani. 2009.149f. Dissertação (Mestrado) - Escola de Engenharia de São Carlos, Universidade de São Paulo, São Carlos.

$\mathrm{O}$ aumento do uso de água para consumos diversos tem gerado o crescimento de pesquisas relacionadas aos recursos hídricos subterrâneos. A quantificação de sua recarga é requisito indispensável para o manejo desses recursos. O objetivo dessa pesquisa é analisar a influência dos eventos de precipitação e de características do solo na variação do nível d'água em área de recarga do Aquífero Guarani, utilizando a Bacia-Piloto do Ribeirão da Onça como local de estudo. A variação do nível d'água foi monitorada em 12 poços no período de setembro de 2004 a agosto de 2008. A Estação Climatológica do CRHEA-USP forneceu as alturas diárias de precipitação, no período de outubro de 2004 a setembro de 2008. Para alcançar os objetivos propostos foram utilizados três métodos estatísticos: técnicas de agrupamento, análise de séries temporais e análises de correlação. Há um padrão de sazonalidade das chuvas na região e, a variação do nível d'água nos poços monitorados acompanha esse padrão, com exceção dos poços localizados em culturas de eucalipto. As técnicas de agrupamento sugerem a formação de cinco grupos de poços. A correlação entre as variações mensais do nível d’água em poços de mesma cultura gerou altos coeficientes. Esse resultado, juntamente com os agrupamentos, mostra que há uma maior influência da cultura de solo na variação do nível d'água, enfatizando a necessidade de estudos mais aprofundados a respeito das características do solo, uma vez que a porosidade também se mostrou como importante característica. Os coeficientes de correlação entre variação do nível d'água no aqüífero e precipitação para intervalos de tempo diários e mensais foram muito baixos, mostrando a existência de um período de defasagem entre os eventos. Verificou-se a existência de uma defasagem de 10 a 20 dias entre precipitação e elevação do nível d'água. A ocorrência de curtos períodos de elevação é resultado de precipitações acumuladas ocorrentes no mesmo intervalo de tempo.

Palavras-chave: águas subterrâneas, chuva, defasagem, métodos estatísticos, agrupamentos. 


\begin{abstract}
GOUVÊA, T. H. Statistical analysis about the influence of precipitation and soil characteristics on the water level fluctuation on recharge area of the Guarani Aquifer System recharge.2009.149f. Dissertação (Mestrado) - Escola de Engenharia de São Carlos, Universidade de São Paulo, São Carlos.
\end{abstract}

The increasing of water use to different consumes have generated the growing of researches related about groundwater resources. The recharge's quantification is a indispensible requirement to management of these resources. The main objective of this research is to analyze the influence of precipitation and soil characteristics on the water level fluctuations on the recharge area of the Guarani Aquifer System, using the Ribeirão da Onça Pilot-Basin to study area. The water level fluctuation was monitoring in 12wells, during the period of September 2004 until August 2008. The Climatology Station of CRHEA-USP provides the data about dairy precipitation, to the period of October 2004 to September 2008. In order to reach the proposal objectives were used three statistical methods: clustering techniques, time series analysis and correlation analysis. There is a seasonal pattern of the rains in the region, and the water level fluctuations have the same behavior, with except of wells located in areas where eucalypt are cultivated. The clustering techniques surgeries the formation of five well's groups. The correlation between months variations water level of the wells generated high coefficients. This result, analyzed with the clustering, shows that there are an more importance of soil culture on the water level fluctuation, empathizing the necessity of more specific studies about the soil characteristics, once a time that the porosity was also showed like a important characteristic. The coefficients of correlation between water level dairy fluctuation on the aquifer and dairy precipitation were very small $(\mathrm{r}<$ $0.5)$, which shows the existence of a lag period between the events. It was verified that this lag varies from 10 to 20 days. The occurrences of shorts periods of elevation of the water level is result of accumulated precipitations currents on the same period.

Key-words: groundwater, raining, lag, statistical methods, clustering. 


\section{LISTA DE ILUSTRAÇÕES}

Figura 1: Gráfico gerado a partir de técnicas de agrupamento para piezômetros do

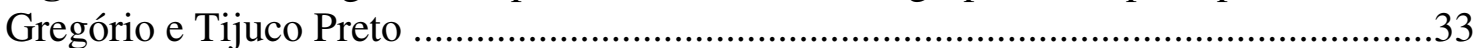

Figura 2: Localização da Bacia Piloto do Ribeirão da Onça..........................................46



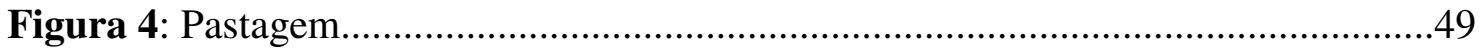

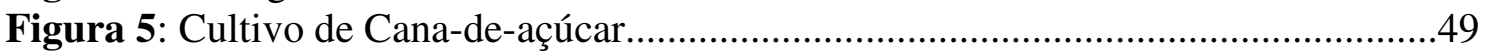

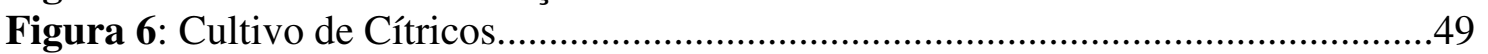

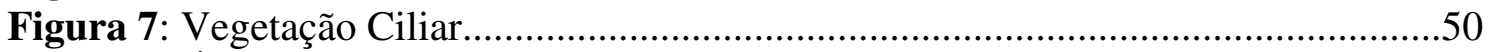

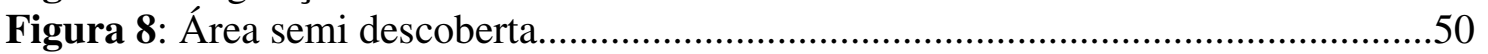

Figura 9: Localização dos poços de monitoramento na Bacia Piloto do Ribeirão da



Figura 10: Variação do nível d'água em um poço, segundo método

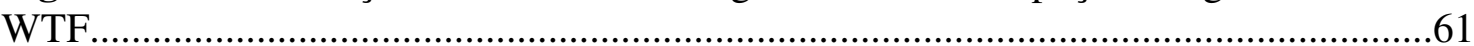

Figura 11: Gráfico esquemático do procedimento para cálculo da defasagem entre precipitação e elevação do nível d’água nos poços

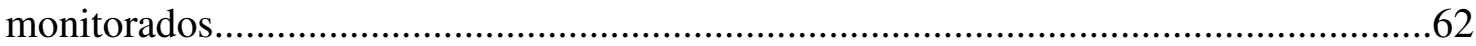

Figura 12:Distribuição mensal pluviométrica para os anos hidrológicos estudados .....65

Figura 13:Precipitação anual nos anos hidrológicos de 2004 a 2008...........................65

Figura 14: Dendograma de agrupamento para os poços monitorados, no período de

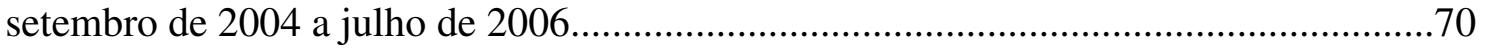

Figura 15: Dendograma de agrupamento dos poços monitorados para o período de

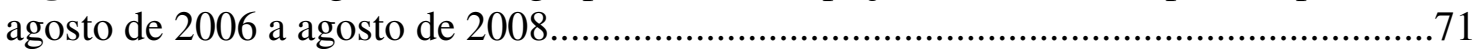

Figura 16: Variação mensal do nível d'água nos poços do grupo 1 ................................74

Figura 17: Variação mensal do nível d'água nos poços do grupo 2..............................74

Figura 18: Variação mensal do nível d'água no poço do grupo 3 .................................75

Figura 19: Variação mensal do nível d'água no poço do grupo 4 .................................75

Figura 20: Variação mensal do nível d'água no poço do grupo 5 .................................76

Figura 21: Correlograma do poço 4, para os anos estudados........................................79

Figura 22: Correlograma do poço 5, para os anos estudados.......................................79

Figura 23: Correlograma do poço 8, para os anos estudados.....................................80

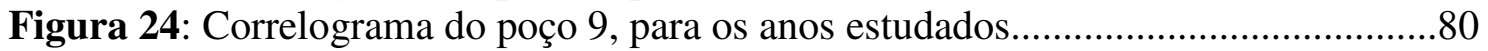

Figura 25: Correlograma do poço 10, para os anos estudados......................................80

Figura 26: Correlograma do poço 13, para os anos estudados....................................81

Figura 27: Correlograma do poço 14, para os anos estudados.....................................81

Figura 28: Correlograma do poço 15, para os anos estudados....................................82

Figura 29: Correlograma do poço 16, para os anos estudados.....................................82

Figura 30: Correlograma do poço 17, para os anos estudados.....................................83

Figura 31: Correlograma do poço 18, para os anos estudados.......................................83

Figura 32: Correlograma do poço 19, para os anos estudados....................................84

Figura 33: Correlograma da série de precipitação diária, para o período de setembro

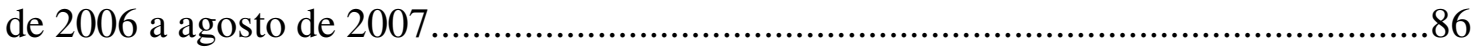

Figura 34: Correlograma da série de precipitação acumulada mensal, para os anos

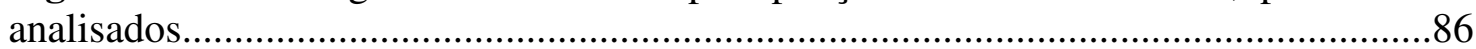

Figura 35: Correlação entre variação do nível d'água e precipitação acumulada no poço 4, localizado em aréa de pastagem, para os anos analisado.........................................92

Figura 36: Correlação entre variação do nível d'água e precipitação acumulada no poço 5, localizado em área de pastagem, para os anos analisados. 
Figura 37: Correlação entre variação do nível d'água e precipitação acumulada no poço 8, localizado em região de cultivo de cítricos, para os anos analisados

Figura 38: Correlação entre variação do nível d'água e precipitação acumulada no poço 9 , localizado em região de cultivo de eucaliptos, para os anos analisados

Figura 39: Correlação diária entre variação do nível d'água e precipitação acumulada no poço 10, localizado em região de cultivo de eucaliptos, para os anos analisados.

Figura 40: Correlação entre variação do nível d'água e precipitação acumulada no poço 13, localizado em região de cultivo de cítricos, para os anos analisados.

Figura 41: Correlação entre variação do nível d'água e precipitação acumulada no poço 14, localizado em região de cultivo de cítricos, para os anos analisados 95

Figura 42: Correlação entre variação do nível d'água e precipitação acumulada no poço 15, localizado em região de cultivo de cana-de-açúcar, para os anos analisados.

Figura 43: Correlação entre variação do nível d'água e precipitação acumulada no poço 16 , localizado em região de pastagem, para os anos analisados.

Figura 44: Correlação entre variação do nível d'água e precipitação acumulada no poço 17, localizado em região de pastagem, para os anos analisados.

Figura 45: Correlação entre variação do nível d'água e precipitação acumulada no poço 18 , localizado em região de pastagem, para os anos analisados.

Figura 46: Correlação entre variação do nível d'água e precipitação acumuada no poço 19, localizado em região de pastagem, para os anos analisados.

Figura 47: Coeficiente de correlação em função de diferentes defasagens de tempo para acumulação de precipitação anterior à variação de nível no poço 4 ......

Figura 48: Coeficiente de correlação em função de diferentes defasagens de tempo para acumulação de precipitação anterior à variação de nível no poço 5 .

Figura 49: Coeficiente de correlação em função de diferentes defasagens de tempo para acumulação de precipitação anterior à variação de nível no poço 8 .

Figura 50: Coeficiente de correlação em função de diferentes defasagens de tempo para acumulação de precipitação anterior à variação de nível no poço 9 .

Figura 51: Coeficiente de correlação em função de diferentes defasagens de tempo para acumulação de precipitação anterior à variação de nível no poço 10 .

Figura 52: Coeficiente de correlação em função de diferentes defasagens de tempo para acumulação de precipitação anterior à variação de nível no poço 13. 105

Figura 53: Coeficiente de correlação em função de diferentes defasagens de tempo para acumulação de precipitação anterior à variação de nível no poço 14

Figura 54: Coeficiente de correlação em função de diferentes defasagens de tempo para acumulação de precipitação anterior à variação de nível no poço 15 .

Figura 55: Coeficiente de correlação em função de diferentes defasagens de tempo para acumulação de precipitação anterior à variação de nível no poço 16 .

Figura 56: Coeficiente de correlação em função de diferentes defasagens de tempo para acumulação de precipitação anterior à variação de nível no poço 17.

Figura 57: Coeficiente de correlação em função de diferentes defasagens de tempo para acumulação de precipitação anterior à variação de nível no poço 18.

Figura 58: Coeficiente de correlação em função de diferentes defasagens de tempo para acumulação de precipitação anterior à variação de nível no poço 19. 


\section{LISTA DE TABELAS}

Tabela 1: Entrada de dados referentes ao mês de abril de 2005, utilizados nos agrupamentos. .55

Tabela 2: Distribuição Pluviométrica para os anos hidrológicos estudados .63

Tabela 3: Seqüência de agrupamentos de acordo com o cálculo da distância euclidiana para o período de setembro de 2004 a julho de 2006.

Tabela 4: Sequiência de agrupamento de acordo com o cálculo da distância euclidiana, para o período de setembro de 2004 a julho de 2006. 72

Tabela 5: Agrupamento dos poços monitorados, a partir de técnicas divisivas, para o período de setembro de 2004 a julho de 2006. .73

Tabela 6: Agrupamento dos poços monitorados, a partir de técnicas divisivas, para o período de agosto de 2006 a agosto de 2008 . .73

Tabela 7: Coeficiente de correlação (Pearson) entre variaçõe mensais do nível d'água nos poços monitorados .88

Tabela 8: Coeficiente de correlação (Pearson) para as variáveis precipitação e variação mensal do nível d'água em escala logarítmica e em escala normal, para o período de setembro de 2004 a setembro de 2008 . .92

Tabela 9: Resumo dos maiores coeficientes encontrados em relação a defasagem.....113 


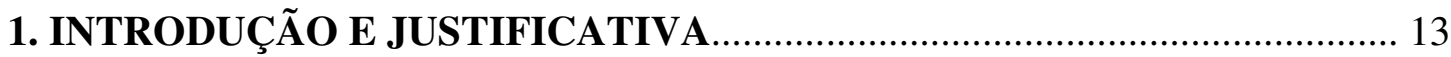

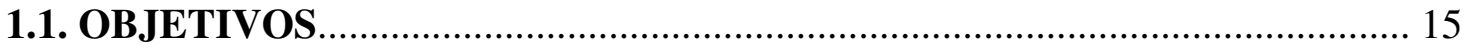

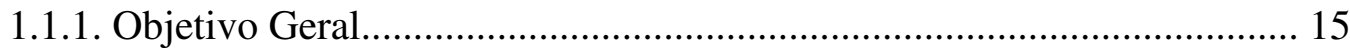

1.1.2. Objetivos Especificos........................................................................... 15

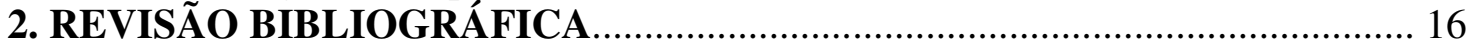

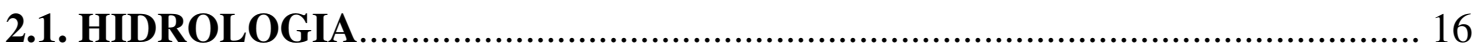

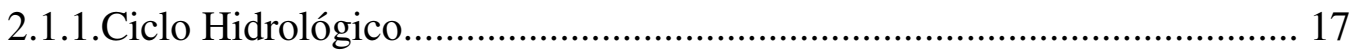

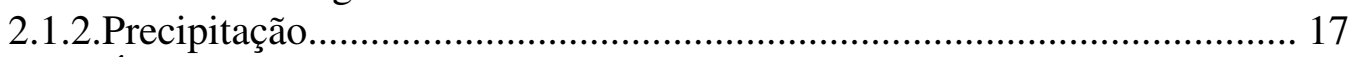

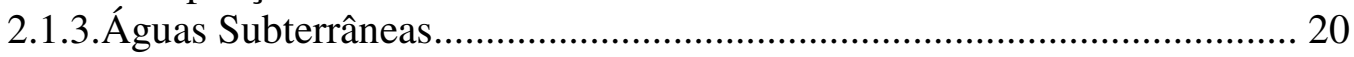

2.1.4.Classificação dos Aquíferos.................................................................. 21

2.1.5.Características Físicas das Águas Subterrâneas......................................... 22

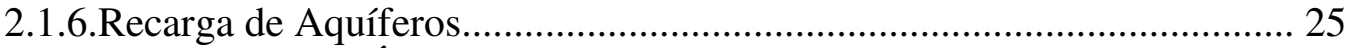

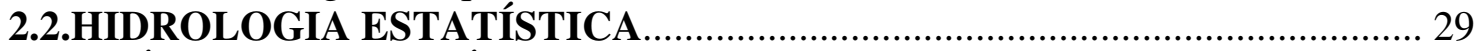

2.3. MÉTODOS ESTATÍSTICOS............................................................... 30

2.3.1.Análise de Agrupamento...................................................................... 30

2.3.2.Teoria das Correlações....................................................................... 38

2.3.3.Análise de Regressão............................................................................. 40

2.3.4.Autocorrelação em Séries Temporais......................................................... 41

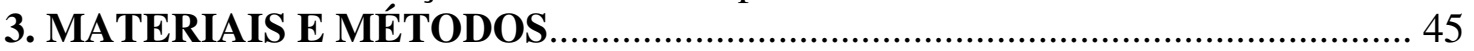

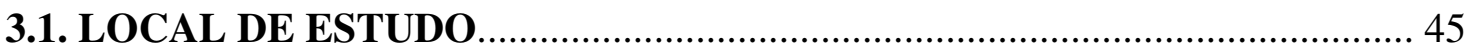

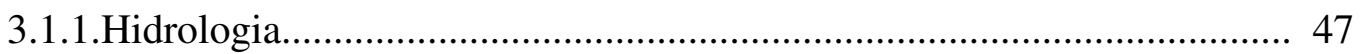

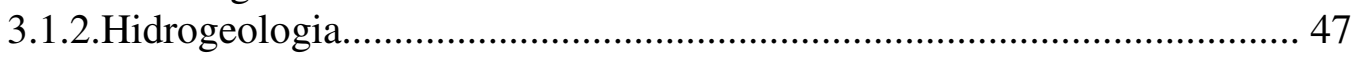

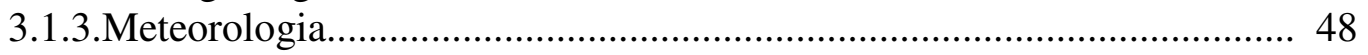

3.1.4.Uso e Ocupação do Solo...……………………………………………. 49

3.2. DADOS DISPONÍVEIS ....................................................................... 50

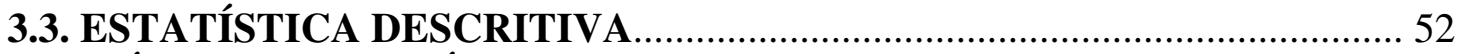

3.4. MÉTODOS ESTATÍSTICOS................................................................ 52

3.4.1.Análise de Agrupamentos...................................................................... 52

3.4.2.Autocorrelação em Séries Temporais........................................................ 57

3.4.3.Análise de Correlação............................................................................ 59

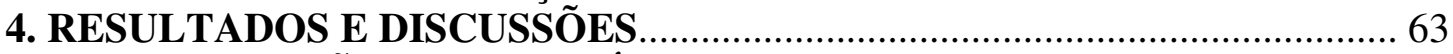

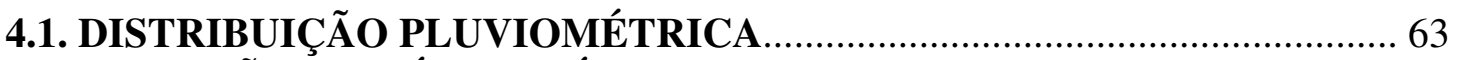

4.2.VARIAÇÃO DO NÍVEL D'ÁGUA NOS POÇOS MONITORADOS.............. 66

4.3. AGRUPAMENTO DOS POÇOS MONITORADOS...................................... 69

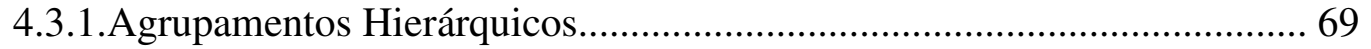

4.3.2.Agrupamentos Divisivos.......................................................................

4.3.3.Definição dos Agrupamentos................................................................... 73

4.4. AUTOCORRELAÇÃO DAS SÉRIES DE PRECIPITAÇÃO E DO NÍVEL

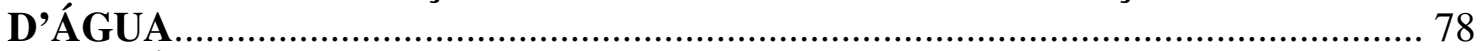

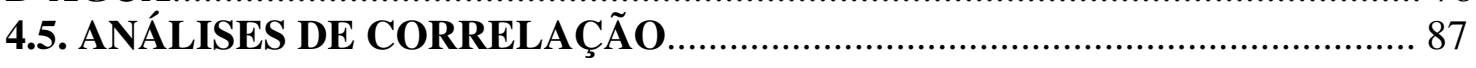

4.5.1.Correlação entre os Poços Monitorados....................................................... 87

4.5.2. Correlação entre Variação Mensal do Nível d'Água e Precipitação Mensal.. 90

4.5.3.Análise de Correlação em Períodos de Elevação do Nível d'Água................ 92

4.5.4.Avaliação da Defasagem entre Precipitação e Variação do Nível d'Água... 100

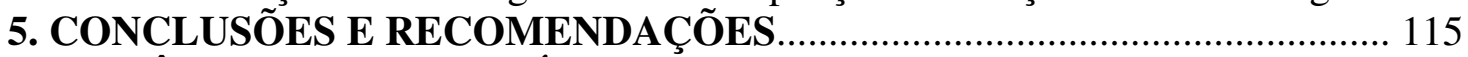

REFERÊNCIAS BIBLIOGRÁFICAS............................................................... 119

APÊNDICES 





\section{INTRODUÇÃO E JUSTIFICATIVA}

A crescente preocupação com a escassez de recursos hídricos superficiais, devido ao crescimento da demanda de água para consumo doméstico, industrial, agrícola, dentre outros, associado à crescente deterioração das águas, tem gerado o aumento de pesquisas a respeito de recursos subterrâneos. Tal fato ocorre, pois se trata, em geral, de águas de boa qualidade, encontradas em quantidades significativas, e disponíveis por longo período de tempo.

O Sistema Aqüífero Guarani (SAG) é um dos aqüíferos transfronteiriços mais importantes do mundo. Diante disso reconhece-se a necessidade de um programa de gerenciamento do mesmo. Estudos Hidrológicos no SAG mostram-se fundamentais para o bom planejamento e uso dos recursos hídricos subterrâneos. Faz-se indispensável, também, um sistema de monitoramento do mesmo, especialmente no que diz respeito a sua disponibilidade, uma vez que a explotação não deve ser maior que a capacidade de recarga.

A quantificação da recarga das águas subterrâneas é um requisito fundamental para o manejo destes recursos. As informações obtidas pelas redes de monitoramento de recursos hídricos são essenciais para detectar os impactos de mudanças do clima e de atividades humanas na quantidade e na qualidade dos aqüíferos. Todo o processo de interação entre aqüíferos e o ambiente pode ser observado somente por uma rede de monitoramento (ZHOU, 1996).

Há uma grande dificuldade na determinação da recarga de aqüíferos e suas estimativas possuem elevado grau de incerteza. Nas áreas de recarga dos aqüíferos, uma parte da água que infiltra no solo, participa do escoamento básico, enquanto que outra parte pode ir para as porções profundas ou confinadas podendo se transformar em recarga profunda (GOMES, 2008). 
Em águas subterrâneas, a precipitação possui grande importância, uma vez que, segundo Yi e Lee (2003), é a fonte primária no processo de recarga de aquífferos. No entanto há grande dificuldade de estabelecer a relação entre tais fenômenos. Devido à irregularidade da coleta dos dados, há uma maior dificuldade na aplicação de modelos numéricos e computacionais.

Face ao exposto, o presente projeto busca avaliar a correlação entre os eventos de chuva e o processo de recarga em áreas de afloramento de aquíferos. Para tal, serão utilizados métodos estatísticos, visando à determinação da correlação entre precipitação e variação do nível em piezômetros (aqüífero livre). A partir de pesquisa bibliográfica sobre os possíveis métodos estatísticos e software a serem aplicados, aliados à coleta e análise de dados, pretende-se estabelecer a correlação existente entre os eventos de precipitação e as mudanças no nível do aqüífero. Conseqüentemente, estes dados possibilitarão o melhor entendimento do processo de recarga na área de afloramento, mostrando-se como importante instrumento de gerenciamento de recursos hídricos subterrâneos.

O estudo será realizado com base em dados hidrológicos coletados no período de setembro de 2004 a agosto de 2008 na bacia piloto do Ribeirão da Onça. Essa bacia tem representado foco de estudos sobre os processos de recarga do aqüífero (POMPÊO, 1983; DAVINO, 1984; CONTIN NETO, 1987; CUNHA, 2003; BARRETO, 2006; WENDLAND et al. 2007; GOMES, 2008). Tais estudos disponibilizam uma série de dados significativos, os quais justificam análises no que concerne aos processos relativos ao balanço hídrico nesta bacia. Uma característica importante desta bacia é situar-se, em sua maior parte, em uma região de afloramento da Formação Botucatu, podendo fornecer elementos de grande interesse para o aprofundamento dos conhecimentos sobre a recarga do Sistema Aqüífero Guarani. 


\subsection{OBJETIVOS}

\subsubsection{Objetivo Geral}

O objetivo principal do presente projeto é aumentar os conhecimentos sobre os mecanismos de recarga do SAG, especificamente os relacionados à influência dos fenômenos de precipitação em áreas de afloramento.

Através do monitoramento com equipamentos de medição (piezômetros, pluviômetro e estação climatológica, equipados com datalogger), pretende-se avaliar as variações do nível da superfície livre do aquífero em função da precipitação registrada, utilizando, para tal, métodos estatísticos. Além disso, objetivou-se avaliar a influência de determinadas características físicas da região estudada na variação do nível d'água nos poços monitorados. As características escolhidas foram: porosidade e coeficiente de evapotranspiração.

\subsubsection{Objetivos Específicos}

No decorrer da pesquisa pretende-se atingir os objetivos específicos estão listados abaixo:

1. Avaliar a variação do nível d'água nos poços monitorados, buscando definir períodos de elevação e declínio;

2. Definir padrões de sazonalidade presentes nas séries de variação do nível d'água e de precipitação;

4. Definir a formação de agrupamentos de poços de monitoramento, a partir de características de solo e variação do nível d'água;

5. Analisar a relação, a partir de métodos estatísticos, entre a dinâmica da precipitação e as variações no nível d'água nos poços monitorado em área de recarga do aquíf́ero;

6. Avaliar a defasagem ocorrente entre um evento de precipitação e uma elevação no nível d'água no aquiífero. 


\section{REVISÃO BIBLIOGRÁFICA}

A revisão bibliográfica é iniciada com considerações gerais a respeito de Hidrologia. Em seguida, é mostrada a definição de ciclo hidrológico, enfatizando o fenômeno de precipitação e sua influência no processo de recarga de aqüíferos, e a ocorrência das águas subterrâneas. Posteriormente, são feitas considerações iniciais sobre Hidrologia Estatística, uma vez que a estatística se mostra como ferramenta para o desenvolvimento do trabalho. Finalizando, é feita a revisão dos métodos estatísticos utilizados na pesquisa, sendo eles: análise de agrupamento; séries temporais e teoria das correlações.

\subsection{HIDROLOGIA}

De acordo com Tucci (2002), a Hidrologia é uma ciência interdisciplinar que trata da ocorrência, circulação e distribuição de água na Terra. Os métodos quantitativos têm sido explorados a partir de metodologias matemáticas e estatísticas, almejando melhores interpretações dos dados relativos aos recursos hídricos.

Todd (1959) e Ramos et al. (1989) definem a hidrologia de águas subterrâneas como a ciência que estuda a ocorrência, movimentação e distribuição de água na porção subterrânea da Terra. Pode ser encarada como uma ciência especializada combinando elementos de Geologia, Hidrologia e Mecânica dos Fluidos. Para ambos os autores, a água subterrânea tem sua origem na superfície e está intimamente ligada à água superficial.

As relações entre a hidrologia superficial e a subterrânea são, cada dia, mais estreitas e necessárias. A Hidrogeologia centra-se no estudo de formações geológicas que podem proporcionar água em quantidades suficientes para suprir as necessidades humanas. Esse estudo permite maior conhecimento do funcionamento dos aqüíferos, 
processos de recarga, alimentação, relações com o meio geológico em que se encontram, relações com outros aqüíferos e influências que o homem pode provocar (CUSTODIO e LLAMAS, 1996).

\subsubsection{Ciclo Hidrológico}

A água encontra-se permanentemente em movimento, em um ciclo cuja fonte principal de energia é o sol e cuja força atuante, fechando o ciclo, é a aceleração da gravidade. Desta forma, pode-se definir o ciclo hidrológico como um sistema fechado com armazenamento de água na superfície, em rios e lagos, nos oceanos e na atmosfera. Da água que atinge o solo, parte transforma-se em escoamento superficial, parte é armazenada em depressões e parte irá infiltrar-se no solo. Sobre o subsolo, age a evaporação, além da água dali retirada pelas plantas e que retorna à atmosfera, através da transpiração. Parte da água infiltrada irá alimentar os reservatórios subterrâneos, que eventualmente irão escoar, atingindo rios e oceanos (RAMOS et al. 1989).

\subsubsection{Precipitação}

Um dos componentes primários do ciclo hidrológico é a precipitação. Sua distribuição tanto no espaço quanto no tempo é variável, sendo, portanto, considerada um fenômeno descontínuo (CUSTODIO e LLAMAS, 1996).

A precipitação é entendida em Hidrologia como toda água proveniente do meio atmosférico que atinge a superfície terrestre. A disponibilidade de precipitação em uma bacia durante o ano é fator determinante para quantificar, entre outros, a necessidade de irrigação de culturas e abastecimento de água doméstico e industrial. A determinação da intensidade da precipitação é importante para o controle de inundação e da erosão do solo. Por sua capacidade de produzir escoamento, a chuva é considerada o tipo de precipitação mais importante para a Hidrologia (TUCCI, 2002). 
De acordo com Tucci (2002), as precipitações podem ser classificadas como:

- Convectivas: chuvas de grande intensidade e pequena duração, restritas a pequenas áreas. Ocorrem devido bruscas ascensões de ar menos denso que atinge o nível de condensação com formação de nuvens e precipitações;

- Orográficas: chuvas de pequena intensidade e grande duração e, se formam a partir do encontro de ventos quentes e úmidos com barreiras montanhosas, elevando-se e resfriando, ocorrendo condensação de vapor;

- Frontais: formadas pela interação entre massas de ar quentes e frias, são chuvas de grande duração, média intensidade e atingem grandes áreas.

A medição de precipitação é tarefa importante, uma vez que se trata, como já dito, de um fenômeno de grande importância no ciclo hidrológico, bem como para o gerenciamento de recursos hídricos. Dentre os diferentes métodos de medição, destacase o uso de pluviômetros e pluviógrafos. Também podem ser feitas medidas de precipitação através de radares meteorológicos ou imagens de satélite (SANTOS, 2001).

É preciso especial atenção com os dados coletados, os quais devem passar por análises antes do uso, buscando evitar a ocorrência de erros. É comum a existência de lacunas nas séries de dados coletados. Para preencher tais lacunas, após a verificação dos dados, os mesmos devem ser submetidos a métodos como: método de ponderação regional; método de regressão linear; método de ponderação regional com base em regressões lineares, etc. (TUCCI, 2002). 


\subsubsection{Influência da Precipitação na Recarga}

Barreto (2006) afirma que processos de recarga através da precipitação em aqüíferos livres são complexos, já que não há ligação direta entre esses fenômenos. $\mathrm{O}$ processo envolve o fluxo de água na zona não-saturada, que está sujeita à evapotranspiração e aos fluxos subsuperficiais. Além disso, a taxa de infiltração depende de muitos parâmetros que são variáveis no tempo e espaço.

Rennols et al (1980) utilizaram um método auto-regressivo linear para relacionar a precipitação com o nível da superfície freática.Tais autores mostraram que parâmetros lineares não são aplicáveis para fenômenos hidrológicos. Além disso, o modelo usado não considera outros fenômenos de fundamental importância, como é o caso da infiltração e da interceptação.

Viswanathan (1984) também estudou a relação entre precipitação e recarga em aqüíferos não-confinados. Para este autor, chuvas isoladas e de pouca intensidade não exercem influência significativa no nível de água no aqüífero. Segundo ele, a recarga depende em demasia da altura e do histórico de precipitações.

Moon, Woo e Lee (2003) utilizaram Análise de Componentes Principais (PCA) para estudar a variação no nível do aqüífero em períodos chuvosos. Para este autor, a dificuldade de estimar as taxas de recarga de um aqüífero encontra-se na incerteza de parâmetros componentes do balanço hídrico. Nos aquíferos livres, tal dificuldade é agravada pelo fato de, em geral, haver uma maior lentidão nas respostas aos fenômenos de precipitação, ou seja, não se pode definir, imediatamente após um evento de chuva, a taxa de recarga produzida por essa. Tais dificuldades geram a necessidade de estudos de longo prazo em sistemas hidrológicos subterrâneos.

Em seus estudos, Contin Neto (1987) e Pompêo (1990) verificaram existir correlação entre a precipitação e a recarga na Bacia do Ribeirão da Onça - SP. Pompêo 
(1990) estimou que a recarga correspondeu a 8\% da precipitação. Contin Neto (1987) mostrou que no período chuvoso, de maio de 1985 a maio de 1986, a correlação entre a precipitação e a recarga do aqüífero é de 0,99 , a partir de estudo do balanço hídrico da região.

\subsection{3. Águas Subterrâneas}

As águas subterrâneas constituem uma fase do ciclo hidrológico. As formações da crosta terrestre portadoras de água atuam como condutos para a transmissão e como reservatórios para o armazenamento de água. A água penetra nessas formações através da superfície do terreno, de corpos d'água superficiais ou de formações adjacentes, após o que percorre lentamente distâncias variáveis até o seu retorno à superfície por ação do fluxo natural, das plantas ou do homem. As águas subterrâneas, quando mencionadas sem nenhuma especificação hidrogeológica, são geralmente compreendidas como sendo toda água que ocupa todos os vazios de um estrato geológico (TODD, 1959).

Praticamente toda a água subterrânea origina-se de água superficial. As principais fontes de reabastecimento natural incluem a precipitação, cursos d'água, lagos e reservatórios. Outras contribuições conhecidas como reabastecimento artificial, ocorrem do excesso de irrigação, percolação proveniente de canais, e águas propositadamente fornecidas a fim de aumentar o abastecimento das águas subterrâneas (TODD, 1959).

Os aqüíferos são formações geológicas que permitem que uma quantidade apreciável de água se mova através delas sob condições usuais de campo. Reservatórios de águas subterrâneas e formações portadoras de água são usados comumente como sinônimos. De acordo com Ramos et al. (1989) um aqüífero transmite quantidades significativas de água, sob gradientes hidráulicos naturais. 
Já os aqüicludes são formações geológicas que podem conter água, mas não permitem sua movimentação de um lugar para o outro, em condições naturais e em quantidades significativas (TUCCI, 2002). Para Ramos et al. (1989), há ainda os aqüitardes que são formações de baixa permeabilidade, que armazenam água, mas não podem suprir poços de abastecimento. As camadas de argila que separam muitos aqüíferos confinados são bons exemplos de aqüitardes transmitindo água através de drenagem vertical. Em estudos de aquiíferos, aqüitardes são também conhecidos como camadas confinantes drenantes. Há também as formações geológicas denominadas aqüifugos, que não armazenam e nem permitem movimentação de água (CUSTODIO e LLAMAS, 1996).

\subsubsection{Classificação dos Aqüíferos}

A maioria dos aquíferos possui grande extensão em área, e podem ser visualizados como reservatórios de armazenamento subterrâneo. Em geral, são classificados como confinados ou não-confinados, dependendo da presença ou ausência da superfície livre (TODD, 1959). A superfície livre também pode ser denominada de superfície freática e é definida como a superfície superior da zona de saturação que está em contato direto com a pressão atmosférica (RAMOS et al. 1989).

Desta forma, tem-se:

- Aquíf́eros não-confinados: aqueles em que o nível d'água serve como superfície superior da zona de saturação. É também conhecido como livre, freático, ou não artesiano. O termo não-confinado significa que a superfície livre não está impedida de movimentar-se para cima e para baixo. Aqüíferos não-confinados são usualmente os primeiros materiais saturados encontrados em um programa de perfuração (TODD, 1959; RAMOS et al. 1989). 
- Aquíferos confinados: podem ser chamados de artesianos (jorrantes) ou sob pressão, e ocorrem quando o nível d'água está confinado sob pressão maior do que a atmosférica por estratos sobrejacentes relativamente impermeáveis. São limitados abaixo e acima por materiais relativamente impermeáveis. Estes estratos de baixa permeabilidade separam os materiais que formam o aqüífero de permeabilidade mais alta do contato direto com a pressão atmosférica e impedem o movimento ascendente e descendente da água (TODD, 1959; RAMOS et al. 1989).

Tucci (2002) ressalta que os aqüíferos confinados são geralmente aqüíferos de grande produção, enquanto que os aquíferos livres são os mais explorados devido ao fácil acesso. Custodio e Llamas (1996) enfatizam a existência de um terceiro tipo de aquífero: os semi-confinados, que podem ser considerados casos particulares dos aquífferos confinados, pois a parte inferior e trechos da parte superior que os envolvem não são totalmente impermeáveis.

\subsubsection{Características Físicas dos Aquíferos}

A água subterrânea move-se muito lentamente em comparação com a água superficial. O seu fluxo é evidentemente laminar. A ocorrência de água no subsolo pode ser dividida em zona de saturação e aeração. Na zona de saturação todos os interstícios estão preenchidos com água sob pressão hidrostática. A zona de aeração consiste em interstícios parcialmente ocupados por água e parcialmente por ar (TODD, 1959). Nessa zona, os poros contêm água e ar (ou vapor de água), sendo limitada pela superfície do terreno e pela linha de saturação. Pode-se diferenciar em três zonas: a zona de água do solo (cinturão de umidade onde as plantas se desenvolvem), a zona intermediária e a zona capilar (formada por ascensão capilar). É também denominada de zona vadosa. 
As zonas não saturadas estendem-se desde a superfície até a parte superior da franja capilar. A água dessa zona encontra-se sob sucção, devido à tensão superficial entre ela e o ambiente geológico. Assume-se que o ar na zona não-saturada pode moverse livremente, a partir da superfície do solo, através de todos os espaços abertos (TODD, 1959).

Já as zonas saturadas são limitadas superiormente pela superfície freática (submetida à pressão atmosférica) em que a água preenche todos os espaços existentes entre os materiais do solo. Quando se fala em água subterrânea, em geral, refere-se à zona saturada. Inferiormente, é delimitada por uma barreira impermeável. As fontes, os poços e as correntes efluentes têm origem na zona de saturação. Na linha de saturação, a pressão da água é igual à pressão atmosférica (TODD, 1959).

As zonas não-saturadas encontram-se, geralmente, acima de zonas saturadas. Não é possível a demarcação rígida entre as duas zonas, porque elas possuem um contorno interdependente e a água pode mover-se de uma zona para outra em qualquer direção. A franja capilar, no entanto, pode separar a zona não-saturada da zona saturada. Sua espessura varia de alguns centímetros, nos terrenos de cascalhos, a vários metros, nos sedimentos argilosos. Esta zona pode ser saturada e ainda assim pode existir pressão negativa (TODD, 1959).

Algumas características físicas são de grande importância para o estudo das águas subterrâneas, especialmente no que concerne ao entendimento dos processos de recarga. A seguir, serão definidos os conceitos das principais características. Foge do escopo deste trabalho detalhar as mesmas. 
- POROSIDADE

Com relação ao processo de variação de nível ou armazenamento em aqüífero livre (sujeito à pressão atmosférica), a porosidade é uma das principais propriedades físicas dos solos ou rochas, a ser determinada. É expressa pela relação entre o volume de vazios (ou ocupados por ar ou água) de um material e seu volume total. A porosidade total representa a quantidade máxima de água que um dado volume de material geológico pode conter. No caso da zona não-saturada, a porosidade total é igual ao valor máximo para o teor de umidade.

Gomes (2008) enfatiza que a porosidade acima definida é denominada porosidade primária. Além da porosidade primária, há aquela referente às fraturas e cavidades de dissolução (porosidade secundária), as quais resultam de uma gama de processos físicos e químicos.

\section{- CONDUTIVIDADE HIDRÁULICA}

A condutividade hidráulica constitui uma importante propriedade, a qual interfere no movimento da água nos solos, e pode ser definida como sendo a maior ou menor facilidade com que a água pode fluir em um determinado solo através de seus vazios. Assim, é a medida da habilidade de um aqüífero de conduzir água sob a influência do gradiente de uma superfície potenciométrica (MAZIERO, 2005).

A água no solo flui devido à presença de gradientes potenciais, escoando da zona com maior potencial para uma de menor potencial. O movimento de água no solo, sob influência do gradiente hidráulico, deve ser analisado sob duas distintas situações: condição de saturação e de não-saturação. O fator mais importante que diferencia as duas situações é que a condutividade hidráulica é máxima na zona saturada. Na zona não-saturada, o fluxo ocorre em qualquer condição de umidade abaixo da saturação, 
envolvendo funções entre diversas variáveis (teor de umidade, potencial hidráulico e condutividade hidráulica) (FETTER, 1994).

\section{- RENDIMENTO ESPECÍFICO}

O rendimento específico é definido como a relação entre o volume de água drenado por gravidade e de uma amostra de solo saturada e o volume total dessa

amostra. É um importante parâmetro na obtenção da taxa de recarga, principalmente, nos métodos que utilizam flutuações do nível d'água (WTF - Water Table Fluctuation; CRD - Cumulative Rainfall Departure). Contudo, os valores relatados para o rendimento específico na literatura são bastante variáveis, assim como os métodos para sua obtenção. Outras vezes, acontece a substituição do parâmetro rendimento específico por algum outro (porosidade efetiva, coeficiente de armazenamento) (GOMES, 2008).

\subsubsection{Recarga de Aqüíferos}

A recarga das águas subterrâneas é definida como o fluxo de água que alcança o aqüífero, constituindo uma adição ao reservatório de água subterrânea. Isso ocorre, em geral, a partir da percolação vertical proveniente da zona vadosa e do escoamento lateral a partir das fronteiras do sistema. A recarga subterrânea de certa área é normalmente considerada a infiltração em excesso na mesma área (DE VRIES e SIMMERS, 2002).

Barreto (2006) conceitua, ainda, a recarga como um processo de movimento de água que atinge a zona saturada sob forças gravitacionais, ou em uma direção específica por condicionamento hidráulico. Segundo Maziero (2005), ocorre uma confusão entre o termo recarga e o termo infiltração. Buscando evitar tal confusão de conceitos, define-se infiltração como o movimento de água da superfície para dentro do subsolo enquanto que a recarga é a parcela da infiltração que atinge a superfície livre, ou zona saturada, por uma direção descendente (RUSHTON e TOMLINSON, 1979; LERNER et al. 1993). 
A interação entre clima, geologia, morfologia, condições do solo e vegetação determina o processo de recarga, principalmente por ter origem nos fenômenos de precipitação. As taxas de recarga são limitadas, em grande parte, pela água disponível na superfície do terreno, controlada por fatores climáticos, como a precipitação e evapotranspiração e pelas características geomorfológicas superficiais (topografia, solo e cobertura vegetal) (MAZIERO, 2005).

Em áreas mais úmidas, a recarga encontra-se controlada pela precipitação efetiva, capacidade de infiltração do solo e capacidade de armazenamento e transporte da subsuperfície. Já nas áreas semi-áridas, a recarga subterrânea depende, particularmente, de eventos de chuva em grandes intensidades, bem como de acúmulos de chuva em depressões e rios, e a habilidade da água da chuva de "escapar" da evapotranspiração pela rápida percolação. Em locais com vegetação pobre ou com solos permeáveis, fraturados, aliados a alta intensidade de chuvas, criam-se condições mais favoráveis para a recarga (DE VRIES e SIMMERS, 2002).

Os mecanismos de recarga de aqüíferos são controlados pelo balanço entre os diversos componentes do ciclo hidrológico. Assim, o conhecimento de tais mecanismos, além de permitir o maior controle no que diz respeito ao uso dos recursos subterrâneos, mostra-se indispensável nos estudos de manejo e gerenciamento de bacias hidrográficas e recursos hídricos em geral.

De Vries e Simmers (2002) classificam os processos de recarga em três categorias:

- Recarga Direta: é um processo que acontece abaixo do ponto de impacto da precipitação por movimento vertical através da zona não-saturada. A recarga 
direta pode ser definida como a parcela da precipitação que vence a zona não-saturada e soma-se à reserva subterrânea;

- Recarga Indireta: descreve os processos em que a recarga ocorre por características introduzidas pela urbanização, assim como por rios e depressões de superfícies topográficas (reservatórios, lagos, etc.);

- Recarga Localizada: é um processo pontual de recarga, em que a água movese em curtas distâncias lateralmente antes da infiltração.

Balek (1988) definiu quatro tipos de recarga, baseado no fator tempo:

- Recarga Curta: que ocorre após grandes eventos de chuva;

- Recarga Sazonal: que ocorre durante o degelo em regiões de clima temperado ou em períodos chuvosos em regiões com estações secas e chuvosas bem definidas;

- Recarga Perene: que ocorre nos trópicos úmidos onde existe um fluxo contínuo de água;

- Recarga Histórica: aquela que ocorreu há um longo tempo atrás e que foi responsável pela formação dos recursos hídricos subterrâneos existentes.

Diversos autores têm pesquisado os processos de recarga e esbarram na dificuldade de quantificação e controle de alguns fatores, o que exige a utilização de mais de um método para a comparação entre os resultados. Os procedimentos de estimativa de recarga não são universais, ou seja, podem ser aplicados em uma determinada região satisfatoriamente e, não serem bem sucedidos se utilizados em outro local.

Não é objetivo desta pesquisa a estimativa de taxas de recarga na área de estudo. Desta forma, os vários métodos existentes não serão abordados nesta revisão bibliográfica, com exceção do Método de Flutuação da Superfície Livre (WTF), visto 
que parte dele será utilizada no desenvolvimento da metodologia, para o alcance dos objetivos propostos. Diversos trabalhos (CONTIN NETO, 1987; DAVINO, 1984; POMPÊO, 1983; CUNHA, 2003; MAZIERO, 2005; BARRETO, 2006; WENDLAND et al. 2007) abordam de maneira detalhada tal tópico. Antes de abordar o método de Flutuação da Superfície Livre, serão citados alguns métodos utilizados:

- Métodos diretos: Lisímetro;

- Métodos Baseados no Balanço Hídrico: Método CRD; Método da Flutuação da Superfície Livre;

- Métodos dos Traçadores;

- Métodos Numérico-Matemáticos;

\subsubsection{Método de Flutuação da Superfície Livre (WTF)}

Esse método é utilizado para aqüíferos não-confinados, necessitando do conhecimento do rendimento específico, bem como das variações de nível d'água ao longo do tempo. Tal método permite a verificação dos mecanismos de movimentação da água na zona não-saturada (HEALY \& COOK, 2002). Parte-se do principio de que as elevações nos níveis d'água originam-se de águas de recarga subterrânea, atingindo a superfície piezométrica. Assim, a recarga é calculada a partir da fórmula:

$$
R=S_{y} \frac{d h}{d t}=S_{y} \frac{\Delta h}{\Delta t}
$$

em que $\mathrm{R}$ é a recarga, $\mathrm{S}_{\mathrm{y}}$ é o rendimento especifico, $h$ é a altura do superfície freática, e $t$ é o tempo. Essa equação assume que a água que atinge o nível freático é armazenada, e todos os outros componentes do balanço hídrico subterrâneo são nulos durante o período de recarga. De acordo com Healy e Cook (2002), a aplicação da equação para 
cada elevação individual do nível d'água determina uma estimativa da recarga total. Assim, $\Delta h$ é a diferença entre o pico de subida e o ponto mais baixo da curva de recessão anterior extrapolada até o instante do pico. A curva de recessão antecedente é o traço que a hidrógrafa do poço de monitoramento teria seguido na ausência de elevação do nível d'água (MAZIERO, 2005).

O método WTF pode ser visto como uma aproximação integrada e não como uma medida pontual quando comparado com os métodos aplicados na zona nãosaturada (HEALY e COOK, 2002).

\subsection{HIDROLOGIA ESTATÍSTICA}

Ainda que existam métodos matemáticos para previsão de fenômenos hidrológicos, os métodos de análises estatísticas tem se mostrado como de grande importância na previsão e acompanhamento de processos hidrológicos.

Os processos hidrológicos são aleatórios. Isso significa que suas realizações não são conhecidas, a priori. Os exemplos de variáveis aleatórias temporais em Hidrologia são abundantes: chuva, vazão, temperatura, insolação, velocidade e direção do vento (TUCCI, 2002). As variáveis hidrológicas e hidrometeorológicas têm sua variabilidade registrada por meio das chamadas séries temporais, as quais reúnem as observações ou medições daquela variável, organizadas no modo seqüencial de sua ocorrência no tempo (ou espaço) (NAGHETTINI e PINTO, 2007).

Os processos hidrológicos são geralmente contínuos no tempo e no espaço, ou seja, as variáveis que quantificam o processo podem assumir valores ao longo de pontos temporais ou espaciais. Posto isso, tem-se feito o uso de variáveis aleatórias discretizadas para representar os processos hidrológicos. Isso significa dizer que as 
variáveis têm seus registros separados por determinados intervalos de tempo, ou de distância (TUCCI, 2002).

As séries hidrológicas podem apresentar uma tendência, ou um 'salto', ou uma periodicidade ao longo do tempo, como resultado de variações naturais do clima ou alterações induzidas pela ação do homem. Nesse caso, as séries hidrológicas seriam ditas não-estacionárias ao longo do tempo. Por outro lado, quando certas propriedades estatísticas de uma série hidrológica não se alteram ao longo do tempo, a série é dita estacionária. A série é considerada homogênea se o padrão de variabilidade, em torno de seu valor médio, é único e idêntico, ao longo do tempo (NAGHETTINI e PINTO, 2007).

Assim, a Hidrologia Estatística busca conclusões válidas a respeito do comportamento das variáveis hidrológicas. Contudo, é preciso lidar com as incertezas oriundas dos erros de amostragem, e da própria aleatoriedade dos fenômenos hidrológicos. Nesse sentido, dois fatores são fundamentais para a obtenção de bons resultados: a quantidade dos dados hidrológicos disponíveis, bem como a isenção de erros (de observação e medição) e; a escolha do método estatístico mais adequado para o objetivo do estudo.

\subsection{METÓDOS ESTATÍSTICOS}

\subsubsection{Análise de Agrupamento}

Análises de agrupamentos (cluster analysis) são técnicas estatísticas de reconhecimento de padrões de distribuição de informações. Mostram a existência de estruturas intrínsecas ou comportamento de dados amostrais sem que sejam feitas suposições prévias sobre estes. Assim, essas técnicas objetivam classificar objetos (dados amostrais, informações) em categorias ou grupos (classes) baseados nas 
similaridades ou proximidades entre tais objetos. Desta forma, os dados, também chamados de casos, com maiores similaridades são agrupados, a partir da aplicação de algoritmos, em uma mesma classe, de maneira tal que haja dissimilaridades máximas entre as classes (VEGA et al., 1998).

Segundo Vega et al. (1998), as características das classes nem sempre são conhecidas profundamente, no entanto podem ser determinadas a partir de análises. Os resultados oriundos desta técnica auxiliam na interpretação dos dados obtidos em uma pesquisa e indicam padrões. Muñoz-Diaz e Rodrigo (2004) ressaltam que os objetos alocados em um grupo tendem a ser similares segundo atributos que podem ser calculados através de algoritmos, ou ainda, definidos pelo pesquisador. No entanto, esses atributos, quando utilizados a critério do pesquisador, não indicam a formação prévia de grupos, são apenas parâmetros a serem considerados no agrupamento.

Everitt, Landau e Leese (2001) enfatizam a dificuldade em se "reconhecer" um agrupamento (cluster), pois não há uma estrutura padronizada para tal. Apenas a aplicação da técnica, através de algoritmos desenvolvidos em software estatísticos, permite a verificação de grupos.

Esta técnica não deve ser confundida com métodos de discriminação ou distinção, uma vez que nesses os grupos são conhecidos previamente. Em análise de agrupamento, são definidos atributos (parâmetros) e, a partir desses, serão agrupados os objetos. Tais agrupamentos ocorrem, segundo Everitt, Landau e Leese (1998), a partir de uma coesão interna (homogeneidade dentro de um grupo) e isolamento externo (distinção entre os grupos).

As análises de agrupamentos têm sido utilizadas em diversas áreas. Segundo Everitt, Landau e Leese (2001), dentre elas, pode-se destacar a Astronomia, Psiquiatria, Arqueologia, Marketing. Nos estudos de Climatologia, também se mostram de grande 
importância. Ramos (2001) utilizou as técnicas para analisar os padrões de distribuição das chuvas e suas mudanças na região mediterrânea espanhola, ao longo dos anos. Muñoz-Diaz e Rodrigo (2004) aplicaram análise de agrupamentos a uma série de 88 (oitenta e oito) anos de dados de precipitação, objetivando encontrar zonas climáticas homogêneas em 32 (trinta e duas) localidades da Espanha.

Murray (2007) afirma que as técnicas mostram-se de grande valia no estudo de dados espaciais, uma vez que dão uma idéia geral sobre as similaridades de dados geográficos. Ele ressalta que, para esses dados, o uso exclusivo dessas técnicas não fornece resultados completos que permitam boas conclusões.

$\mathrm{Na}$ Hidrologia, os agrupamentos também têm sido utilizados de maneira satisfatória. Panda et al. (2006), com o objetivo de estudar os processos antropogênicos e naturais, bem como os fatores responsáveis pelas características hidrológicas no sistema de rios Mahanadi, na Índia, utilizaram análise fatorial e análise de agrupamentos. Esses autores afirmam que a partir dos dendogramas, as relações hidrológicas e de qualidade das águas ficam explícitas, mostrando que nas estações de coleta de dados as características dessas relações possuem similaridades.

Ferraro (2006) analisou o comportamento de piezômetros localizados nas bacias do Tijuco Preto e Gregório, a partir dos métodos de técnicas de agrupamento. Este estudo originou dendogramas como o da figura 1, a qual mostra o agrupamento dos piezômetros de acordo com os atributos definidos. 


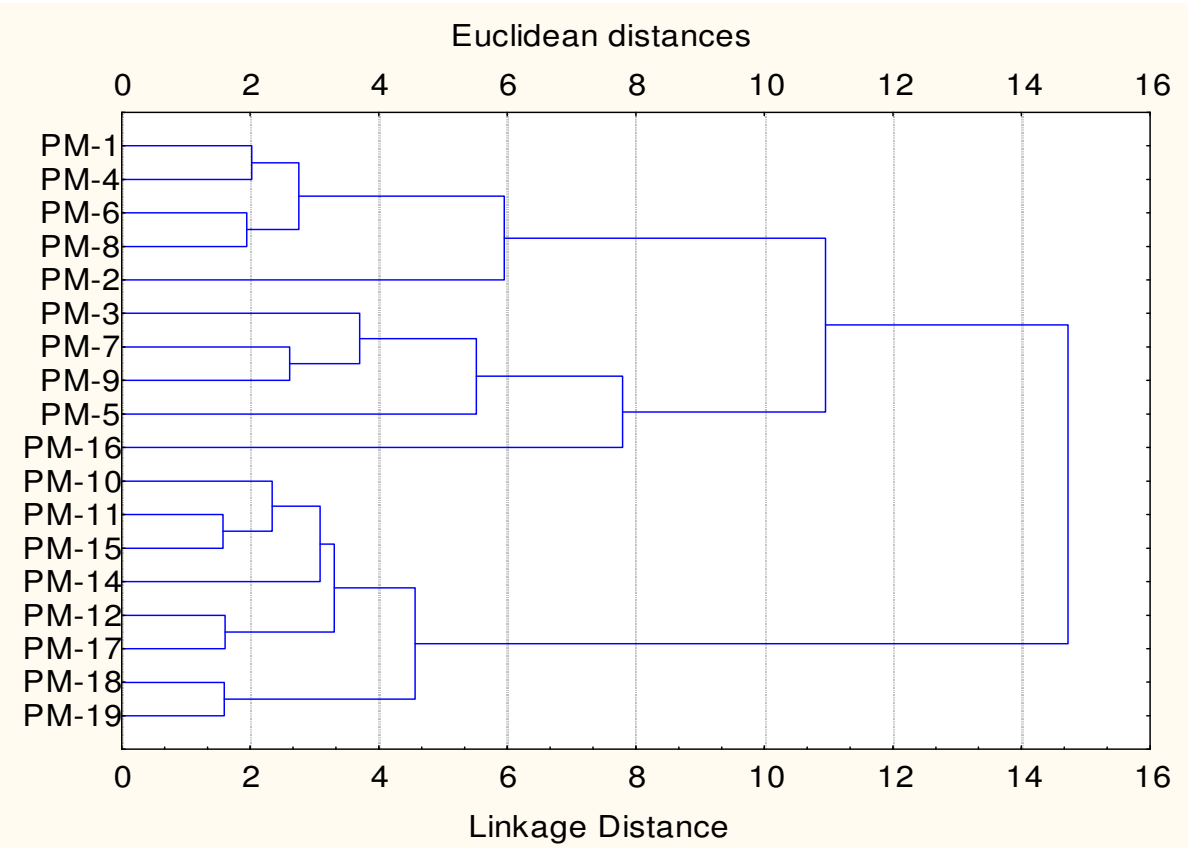

Figura 1: Gráfico gerado a partir de técnicas de agrupamento para os piezômetros das bacias do Gregório e Tijuco Preto (FERRARO, 2006).

\subsubsection{Tipos de Agrupamentos}

Nas técnicas de agrupamento a análise dos dados é feita a partir de uma matriz $\mathrm{X}(\mathrm{n} \times \mathrm{p})$ em que $\mathrm{n}$ são as unidades observacionais (ou seja, os casos/objetos a serem agrupados) e p são as variáveis consideradas no agrupamento. Os perfis (unidades observacionais) são agrupados em pares, considerando todas as possibilidades (ou seja, são feitas combinações 2 a 2 entre todos os objetos analisados) (JOBSON, 1992).

Alguns autores afirmam haver dois tipos de agrupamentos: os hierárquicos e o divisivos. Para Everitt, Landau e Leese (2001), os agrupamentos podem ser aglomerativos ou hierárquicos. Estes últimos são subdivididos em: de fusão e divisivos. Contudo, para todos os autores, as definições de métodos divisivos e hierárquicos (ou de fusão) são as mesmas. No presente trabalho, serão abordados os métodos divisivos e de fusão, pois atendem ao interesse da pesquisa. 
O objetivo da técnica divisiva é separar objetos em grupos consistentes. A escolha preliminar dos objetos pode ser feita aleatoriamente. Ao final do agrupamento, cada objeto encontrar-se-á alocado a um grupo. Nas técnicas hierárquicas (de fusão) os objetos são progressivamente agregados até que se juntem em um único grupo. Cada objeto inicia em um grupo singular. A partir de então, os grupos mais próximos se agregam formando novos grupos, até que reste apenas um grupo contendo todos os objetos (MUÑOZ-DIAZ e RODRIGO, 2004).

Segundo Muñoz-Diaz e Rodrigo (2004), as técnicas hierárquicas (de fusão) são mais implementadas. Seu propósito é o de formar grupos, minimizando as perdas de informações (sem que haja o descarte de dados). De acordo com o critério de agregação, há diferentes métodos de hierarquização. Nas técnicas de agrupamento hierárquicas, a distância entre as amostras é utilizada como uma medida de similaridade. Neste tipo de agrupamento podem ser utilizados três tipos de algoritmos: average linkage; complete linkage; Ward's method (VEGA, 1998). O primeiro deles faz uso da distância mínima entre pares de objetos. Já o chamado "complete linkage" define os agrupamentos a partir da distância máxima entre pares de objetos. E o método Ward define agrupamentos a partir do somatório dos mínimos quadrados.

Na técnica divisiva, os objetos são aleatoriamente dispostos em um número de classes previamente definidas. Eles podem ser distribuídos em uma única classe. A partir da aplicação do algoritmo "k-mean", os objetos são transferidos para classes com as maiores similaridades (RAMOS et al., 2001). O algoritmo $k$-mean é desenvolvido computacionalmente, partindo de uma repartição inicial aleatório especificada por um vetor $\boldsymbol{P}(\mathrm{K}, \mathrm{M})$ com $\mathrm{M}$ observações alocadas em $\mathrm{K}$ grupos. O centróide (média das variáveis analisadas) de cada grupo é computado e a similaridade entre as observações nos grupos é medida por uma função-erro $e$ definida por: 


$$
e[P(M, K)]=\sum_{K} D[I, L(I)]^{2}
$$

em que $L(I)$ é o grupo contendo I casos (observações), $D[I, L(I)]^{2}$ representa a soma dos quadrados dos desvios de cada centróide do grupo (RAMOS, 2001).

Os métodos divisivos seguem o padrão reverso das técnicas hierárquicas, ou seja, todos os dados encontram-se, inicialmente, em um único grupo e, a cada divisão, são formados grupos menores. Everitt, Landau e Leese (2001) atentam para a necessidade de encontrar uma divisão que minimize o somatório do erro quadrático dentro (entre os objetos) de cada grupo.

O modelo de agrupamento mais utilizado tem sido o método hierárquico sequiencial, onde cada dado (objeto) é considerado um grupo separado. Milligan (1987) ressalta a possibilidade de escolha do pesquisador, o qual pode utilizar o agrupamento hierárquico completo como solução, ou ainda, selecionar um nível que represente o número de grupos específicos do seu interesse.

Nas classificações hierárquicas, divisivas ou de fusão, os dados não são particionados em um número de classes ou grupos de uma única vez. Ao contrário, a classificação consiste de uma série de repartições. As classificações hierárquicas não podem ser, uma vez realizadas, corrigidas, ou seja, depois de aplicado o algoritmo e alocados os dados em grupos, estes não poderão ser retirados e colocados em outros grupos (EVERITT, LANDAU e LEESE, 2001).

O progresso e os resultados de uma análise de agrupamento são convencionalmente ilustrados a partir de dendogramas ou diagramas de árvore. Trata-se de uma figura bidimensional que representa a seqüência e as distâncias métricas em que as observações são agrupadas. As distâncias entre os grupos antes de se agregarem também são indicadas nesses diagramas (MUÑOZ-DIAZ e RODRIGO, 2004). 


\subsubsection{Distância Euclidiana}

Muitas investigações utilizando técnicas de agrupamentos têm como ponto de partida uma matriz de proximidade $\mathrm{n} x \mathrm{n}$ com elementos que refletem medidas quantitativas de proximidade, denominadas mais comumente de dissimilaridades, distância de similaridade ou, pelo termo geral, proximidade. Tais proximidades podem ser determinadas de maneira direta ou indireta.

Há vários algoritmos para realizar os agrupamentos, dentre os quais, os mais comuns e utilizados são denominados de single linkage e centroid linkage (agrupa os objetos a partir do cálculo da distância euclidiana quadrática dos centróides). Em geral, todos requerem o cálculo da distância métrica para o seu desenvolvimento.

Como já dito anteriormente, os métodos de agrupamento hierárquicos baseiamse nas medidas de distância para realizar os agrupamentos, sendo a Distância Euclidiana (Ward's Method) a mais utilizada. Esta medida calcula a distância entre as classes formadas pelos objetos.

O grau de similaridade (ou dissimilaridade) entre os pares formados é definido pela Distância Euclidiana, de acordo com a equação:

$$
d_{r s}^{2}=\sum_{j=1}^{p}\left(X_{r j}-X_{s j}\right)^{2}
$$

em que $d_{r s}{ }^{2}$ é a distância euclidiana da matriz X que contem as observações e variáveis a serem agrupadas, r e s são as observações agrupadas dois a dois para todas as variáveis. A raiz quadrada da distância euclidiana define a distância existente entre os grupos formados, utilizando dois objetos (JOBSON, 1992).

Considerando duas classes, $\mathrm{C}_{\mathrm{k}}$ e $\mathrm{C}_{\mathrm{l}}$, as quais se fundem para a formação de uma nova classe, $C_{m}$, a fórmula que define a distância entre esta nova classe e outra, $C_{j}$, é: 


$$
d_{J, M}=\frac{\left(\left(n_{J}+n_{K}\right) d_{J K}+\left(n_{J}+n_{L}\right) d_{J L}-n_{J} d_{K L}\right)}{n_{J}+n_{M}}
$$

em que $n_{j}, n_{k}, n_{l}$ e $n_{m}$ são os números de objetos das classes $J, K, L$ e M, respectivamente, e $d_{j k}, d_{j l}$ e $d_{k l}$ representam a distância (equação 3) entre as observações nas classes J e K, J e L, e K e L, respectivamente (RAMOS et al, 2001).

Segundo VEGA (1998), os agrupamentos hierárquicos gerados a partir do método Ward, por produzirem menores efeitos de distorção, usando maiores informações (dados amostrais) dos grupos, têm fornecido mecanismos mais poderosos de agrupamento, além de terem maior significado estatístico. MUNÕZ-DIAZ e RODRIGO (2004) também afirmam que, mesmo os agrupamentos sendo sensíveis ao método escolhido, o método Ward fornece as soluções mais acuradas.

É importante ressaltar que os algoritmos de agrupamento não restringem dados de entrada a distribuições estatísticas particulares, porque as análises de agrupamento são mais um método objetivo de quantificação de características, de uma gama de observações, que uma ferramenta de inferência estatística (MUÑOZ-DIAZ e RODRIGO, 2004).

Um problema prático na análise de grupos diz respeito à escolha do estágio de parada do agrupamento. Nem sempre é de interesse utilizar o agrupamento final, assim é preciso escolher em que estágio há a solução mais significativa. Não há uma aceitação universal objetiva para essa questão.

Um método tradicional para determinação do nível de parada é vistoriar as distâncias entre os grupos agregados. Quando grupos estão se agregando, logo no inicio do processo, essas distâncias são pequenas, e podem crescer relativamente, passo a passo. No processo pode haver poucos grupos, separados por grandes distâncias. Assim, pode-se utilizar como ponto de parada o estágio anterior ao salto das distâncias, ou seja, 
deve-se atentar para o estágio em que novos agrupamentos geram distâncias muito grandes para que, no momento anterior a esse, o processo seja encerrado. O número de grupos formados até esse momento corresponderá ao nível de parada do agrupamento (MUÑOZ-DIAZ e RODRIGO, 2004).

\subsubsection{Análise de Correlações}

A teoria das correlações objetiva estudar o grau de relacionamento entre duas variáveis, ou seja, busca definir uma medida de covariabilidade. Na análise de correlação não se aceita a idéia de dependência entre as variáveis, existindo, assim, uma influência mútua ou conjunta entre estas. Nesse tipo de estudo, as variáveis são, em geral, consideradas aleatórias e a amostra, proveniente de uma distribuição conjunta dessas variáveis (DEMETRIO e ZOCCHI, 2003).

Para medir o grau de correlação linear simples entre duas variáveis, pode-se utilizar o coeficiente de correlação de Pearson (em geral, indicado por $r$ ), o qual varia entre -1 e +1 . Se o valor de $r$ corresponde a um desses valores, todos os pontos da amostra devem cair sobre uma reta. O coeficiente de correlação de Pearson é dado pela fórmula:

$$
r=\frac{\sum x y-1 / n \sum x \sum y}{\sqrt{\left[\sum x^{2}-\frac{1}{n\left(\sum x\right)^{2}}\right]\left[\sum y^{2}-\frac{1}{n\left(\sum y\right)^{2}}\right]}}
$$

em que $\mathrm{x}$, y são os valores medidos para as duas variáveis e, $\mathrm{n}$ é o número de valores de cada variável.

A correlação entre duas variáveis é positiva se os valores mais altos de uma das variáveis estiverem associados aos valores mais altos da outra variável, e é negativa se os valores mais altos de uma das variáveis estiverem associados aos valores mais baixos 
da outra variável. Segundo VIEIRA (2004), mesmo o coeficiente sendo igual a zero não significa que não exista correlação, e sim que não há correlação linear. $\mathrm{O}$ valor de $r$ mede o grau de dispersão dos pontos. Quanto maior for a dispersão dos pontos, menor será o valor de r, em módulo (VIEIRA, 2004).

Se as amostras das variáveis não estiverem próximas a uma reta de uma equação linear, então se diz que a correlação é não-linear. Nesse caso, equações não-lineares mostram-se mais apropriadas. Uma importante alternativa é a transformação dos valores para a escala logarítmica e a posterior aplicação do cálculo de correlação (SPIEGEL, 1970).

VIEIRA (2004) ressalta a existência de um coeficiente de correlação considerado um caso especial do de Pearson, denominando coeficiente de correlação de Spearman $\left(\mathrm{r}_{\mathrm{s}}\right)$. Esse coeficiente é aplicado para variáveis que não provenham de amostras aleatórias ou quando uma das variáveis não possui distribuição normal. $\mathrm{O}$ coeficiente de Spearman é calculado pela equação:

$$
r_{S}=1-\left[\frac{6 \sum_{i=1}^{n} D_{i}^{2}}{n\left(n^{2}-1\right)}\right]
$$

em que $D_{i}$ é a diferença entre cada par de variáveis e $n$ é o número de valores das variáveis estudadas. Assim como o coeficiente de Pearson, $r_{s}$ pode variar de -1 (correlação perfeita negativa) até +1 ( correlação perfeita positiva).

Vieira (2004) afirma que o estudo de correlação nem sempre tem a importância atribuída, uma vez que o mesmo reduz um conjunto de dados a um único valor. Sendo assim, os resultados de coeficientes de correlação devem ser utilizados para lançar hipóteses e não para estabelecer relações definitivas entre as variáveis. 


\subsubsection{Análise de Regressão}

Segundo Morettin e Bussab (1987), a análise de regressão objetiva estabelecer uma relação entre uma variável resposta y e um conjunto de variáveis independentes $\mathrm{x}_{1}$, $\mathrm{x}_{2}, \mathrm{x}_{3} \ldots, \mathrm{x}_{\mathrm{k}}$. Portanto, almeja encontrar uma equação que explique a variação da variável dependente em função da variação das variáveis independentes. A variável y pode assumir diferentes relações (linear, quadrática, exponencial, etc) em função de x. Devese, assim, verificar o modelo matemático e o tipo de curva que se aproxime da dispersão dos pontos (x, y) em um diagrama de dispersão.

A regressão linear simples tem por objetivo estabelecer uma equação matemática linear (linha reta) que descreva a relação entre duas variáveis (MEDEIROS, 2008). Dessa maneira, o modelo estatístico para essa situação seria (DRAPER; SMITH, 1981):

$$
\mathrm{Y}_{\mathrm{i}}=\beta_{0}+\beta_{1} \mathrm{X}_{\mathrm{i}}+e_{\mathrm{i}}
$$

em que $\mathrm{Y}_{\mathrm{i}}$ é o valor observado para a variável dependente Y no i-ésimo nível da variável

independente $X_{i} ; \beta_{0}$ é a constante de regressão e representa o intercepto da reta com os eixos do $Y ; \beta_{1}$ é o coeficiente de regressão que representa a variação de $\mathrm{Y}$ em função da variação de uma unidade da variável $\mathrm{X} ; e_{\mathrm{i}}$ é o erro associado à distância entre o valor de $\mathrm{Y}_{\mathrm{i}}$ observado e o correspondente ponto na curva do modelo proposto, para o mesmo nível i de X.

Vieira (2004) ressalta que a análise de regressão, quando comparada com o estudo da correlação possui maior significância, pois os resultados obtidos permitem uma interpretação mais segura. Além de medir o grau de relação entre as variáveis, é possível também estudar o grau de incerteza da relação, através dos coeficientes de confiança. 


\subsubsection{Análise de Séries Temporais}

Uma série temporal é uma coleção de observações feitas seqüencialmente ao longo do tempo. Tais observações são dependentes e há o interesse em analisar e modelar esta dependência. Enquanto em modelos de regressão, por exemplo, a ordem das observações é irrelevante para a análise, em séries temporais a ordem dos dados é fundamental (EHLERS, 2005).

A análise de uma série temporal distingue-se das demais análises estatísticas porque há uma importância explícita da ordem em que as observações são feitas. Enquanto em muitos problemas as observações são estatisticamente independentes, em séries temporais, sucessivas observações são dependentes (ANDERSON, 1972). Além disso, há outra importante diferença: embora seja possível variar o tamanho da série observada, usualmente será impossível fazer mais do que uma observação em cada instante. Assim, tem-se apenas uma realização do processo estocástico e uma única observação da variável aleatória no instante $\mathrm{t}$ denotada por $\mathrm{x}(\mathrm{t})$ no caso contínuo e $\mathrm{x}_{\mathrm{t}}$, para $t=1, \ldots, N$ no caso discreto (EHLERS, 2005). Desta forma, as séries temporais podem ser ditas discretas ou contínuas.

Os propósitos do estudo de séries temporais encontram-se ligados à natureza de dependência que as caracteriza. Pode-se destacar: previsão de acontecimentos futuros com base no conhecimento das observações anteriores; controle dos processos que produzem as séries e, ainda, a descrição sucinta das características da série estudada (ANDERSON, 1972).

Um dos objetivos da análise de séries temporais é descrever o comportamento da série, verificar existência de tendências, ciclos e sazonalidades. Para isso, a construção de histogramas pode ser de grande utilidade (MORETTIN e TOLOI, 2006). Este estudo 
requer o uso de técnicas específicas, como, por exemplo: técnicas descritivas, modelos probabilísticos, análise espectral, métodos não-paramétricos (EHLERS, 2005).

Muitas séries temporais apresentam comportamento sazonal, ou seja, um comportamento que tende a se repetir a cada período de tempo. É o caso, na maioria das vezes, de acontecimentos naturais, meteorológicos (EHLERS, 2005).

Box e Jenkins (1994) mostram que as séries temporais são de fundamental importância em algumas áreas de aplicação: na previsão de valores futuros a partir de dados atuais e antecedentes; na determinação de sistemas de entradas e saídas (inputoutput) que podem mostrar os efeitos de saída no sistema estudado gerados pelos dados de entrada e; no desenvolvimento de sistemas de controle.

Consideremos uma série observada $y_{1}, y_{2}, y_{3}, \ldots, y_{T}$. A notação T mostra que as observações de uma variável são feita em $\mathrm{T}$ intervalos equivalentes de tempo. Esses intervalos podem ser denominados de 1,2,.., T. Matematicamente, séries temporais podem ser escritas como:

$$
y_{t}=f(t)+u_{t} \quad \mathrm{t}=1,2, \ldots, \mathrm{T} .
$$

A série observada é considerada como uma sequiência $\{f(t)\}$, que pode ser denominada parte sistemática, e a seqüência aleatória e estocástica $\left\{u_{t}\right\}$, que atende a uma lei de probabilidade, em geral, denominada sinal ou ruído (ANDERSON, 1972).

Anderson (1972) ressalta que tais componentes das séries não são dados observados, e sim, quantidades teóricas. Assim, deve-se considerar $f(t)$ como normas ou leis que definem a série e, $u_{t}$ como irregularidades ocorrentes ao longo do tempo de observação.

As propriedades das séries temporais podem, em sua maioria, ser descritas a partir da decomposição da formula anterior, originando a seguinte: 


$$
X_{t}=T_{t}+C_{t}+R_{t}
$$

em que $T_{t}$ é uma variável de tendência, $C_{t}$ é uma componente cíclica ou sazonal e $R_{t}$ é uma componente aleatória. As variáveis $T_{t}$ e $C_{t}$ correspondem à $\mathrm{f}(\mathrm{t})$, enquanto que $\mathrm{R}_{t}$ é $\mathrm{o}$ ruído ou sinal $\left(\mathrm{u}_{\mathrm{t}}\right)$.

Não há como definir, precisamente, tendência, segundo Ehlers (2005). Dessa maneira, o autor assume a tendência como uma mudança de longo prazo no nível médio da série. A tendência é definida, portanto, a partir de:

$$
X_{t}=\alpha+\beta_{t}+\epsilon_{t}
$$

em que $\alpha$ e $\beta$ são constantes a serem estimadas e $\epsilon$ t denota um erro aleatório com média zero.

Uma importante ferramenta para identificar essas propriedades, de acordo com Ehlers (2005), consiste de uma série de quantidades chamadas coeficientes de autocorrelação amostral. A idéia é similar ao coeficiente de correlação linear.

No caso das séries temporais, busca-se medir a correlação entre as observações de uma mesma variável, em diferentes intervalos de tempo. Assim, dadas n observações de uma série temporal discreta pode-se formar pares $\left(\mathrm{x}_{1}, \mathrm{x}_{2}\right)$. Considerando os pares $\left(\mathrm{x}_{1}\right.$, $\left.\mathrm{x}_{\mathrm{n}-1}\right)$ e $\left(\mathrm{x}_{2}, \mathrm{x}_{\mathrm{n}}\right)$ como duas variáveis, o coeficiente de correlação entre $\mathrm{x}_{\mathrm{t}}$ e $\mathrm{x}_{\mathrm{t}+1}$ é dado por

$$
r_{1}=\frac{\sum_{t=1}^{n-1}\left(x_{t}-X_{1}\right)\left(x_{t+1}-X_{2}\right)}{\sqrt{\sum_{t=1}^{n-1}\left(x_{t}-X_{1}\right)^{2}} \sum_{t=1}^{n-1}\left(x_{t+1}-X_{2}\right)^{2}}
$$

em que $\mathrm{X}_{1}$ e $\mathrm{X}_{2}$ são as médias amostrais de $\mathrm{x}_{\mathrm{t}}=1, \ldots, \mathrm{n}-1$ e, $\mathrm{x}_{\mathrm{t}+1}=2, \ldots, \mathrm{n}$, respectivamente.

$\mathrm{O}$ coeficiente $\mathrm{r}_{1}$ mede as correlações entre observações sucessivas, sendo chamado, portanto, de coeficiente de autocorrelação ou, coeficiente de correlação serial 
usual. Da mesma forma que o coeficiente de correlação usual, as autocorrelações são adimensionais, variando entre $-1<r_{k}<1$ (EHLERS, 2005).

Um gráfico com os k primeiros coeficientes de autocorrelação como função de k é chamado de correlograma, e pode ser uma ferramenta poderosa para identificar características da série temporal (EHLERS, 2005).

Muitos trabalhos na área de Hidrologia e Meteorologia têm utilizado séries temporais, objetivando entender o comportamento de fenômenos de tais áreas. Groppo et al (2005) utilizaram séries temporais para analisar dados de vazão e precipitação de algumas bacias hidrográficas de São Paulo-SP. Os autores conseguiram definir períodos de seca e períodos úmidos, bem como verificar a existência de tendências e mudanças bruscas nos parâmetros. Os mesmos autores concluíram que, para os períodos analisados, a tendência positiva (crescente) das séries de precipitação é acompanhada de tendências positivas das séries de vazão. Além disso, notaram que os rios mais impactados por ações antropogênicas apresentam tendências negativas.

Mayer e Congdon (2007) utilizaram métodos estatísticos, dentre eles, séries temporais, para verificar os efeitos climáticos e antropogênicos no nível da água subterrânea no sudeste de Nevada, EUA. VAN GEER e ZUUR (1996) aplicaram modelos denominados de transferência/ruído, uma extensão do modelo Box-Jenkins, para analisar séries de dados relativos à profundidade do nível d'água subterrânea. $\mathrm{O}$ método mostrou-se de boa utilidade como ferramenta de auxílio no monitoramento, pois permite acompanhar as mudanças das variáveis estudadas, a partir do estudo da autocorrelação das séries. 


\section{MATERIAL E MÉTODOS}

Para atingir os objetivos propostos na presente pesquisa, as seguintes etapas foram desenvolvidas.

\subsection{LOCAL DE ESTUDO}

A Bacia-Piloto do Ribeirão da Onça, área objeto de estudo deste trabalho, está localizada na região Centro-Oeste do Estado de São Paulo, no município de Brotas, entre os paralelos $22^{\circ} 10^{\prime}$ e $22^{\circ} 15^{\prime}$ de latitude Sul e os meridianos $47^{\circ} 55^{\prime}$ e $48^{\circ} 00^{\prime}$ de longitude Oeste. Trata-se de uma área de afloramento de formação Botucatu, o que a torna suscetível à exploração em virtude da vulnerabilidade natural do manancial, facilitando a utilização dos recursos hídricos subterrâneos para atividades econômicas, bem como a exposição à contaminação por meio de atividades agrícolas (GIAMPÁ \& SOUZA, 1982; CONTIN NETO, 1987; MATTOS, 1987; CORRÊA, 1995). A figura 2 mostra a localização da bacia estudada.

Esta bacia tem representado foco de estudos sobre o comportamento dos processos de recarga do aqüífero, bem como do balanço hídrico da região (POMPÊO, 1983; DAVINO, 1984; CONTIN NETO, 1987 CUNHA, 2003; BARRETO, 2006; WENDLAND et al. 2007), uma vez que apresenta características representativas das regiões de afloramento do Sistema Aqüífero Guarani (SAG). Além disso, há, na bacia, equipamentos para a medição do nível do aqüífero e nível superficial do ribeirão. Tal rede de monitoramento encontra-se localizada em diversos tipos de culturas existentes na bacia (BARRETO, 2006). 


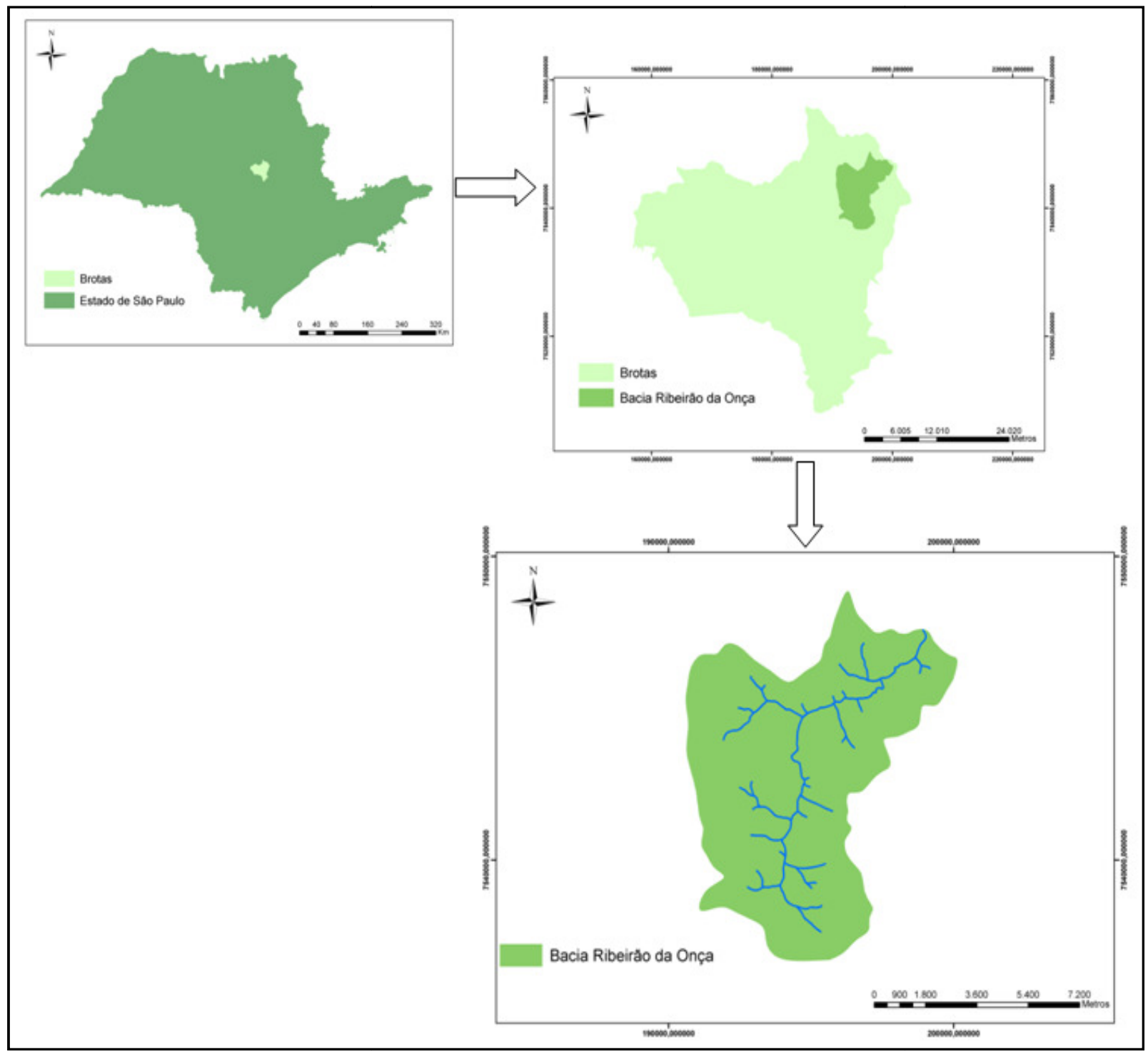

Figura 2: Localização da bacia do Ribeirão da Onça.

Próximo ao Ribeirão da Onça está localizado o CRHEA (Centro de Recursos Hídricos e Ecologia Aplicada da Universidade de São Paulo). A Estação Climatológica do CRHEA coleta e fornece todos os dados meteorológicos necessários ao acompanhamento dos fenômenos hidrológicos.

Algumas considerações sobre características geológicas e hidrológicas da região merecem destaque neste estudo. 


\subsubsection{Hidrologia}

O Ribeirão da Onça é um dos formadores do Rio Jacaré-Guaçú, afluente do Rio Tietê. As principais características físicas desta bacia são (CONTIN NETO, 1987):

- Área da Bacia: $65 \mathrm{~km}^{2}$;

- Perímetro: 42 km;

- Extensão do curso d'água principal: 16 km;

- Declividade média do curso d'água: $8 \mathrm{~m} / \mathrm{km}$;

- Altitude máxima: 840 m;

- Altitude mínima: $640 \mathrm{~m}$.

Segundo Pompêo (1990), a Bacia do Ribeirão da Onça não está sujeita a enchentes, já que seu coeficiente de compacidade $(\mathrm{kc})$, que é a razão entre o perímetro e a circunferência de área equivalente à área da bacia, tem o valor de 1,55. Este coeficiente serve para comparar bacias e indicar a tendência à ocorrência de enchentes, na medida em que seu valor se aproxima de 1 (um). Esse autor afirma ainda que a bacia tem desenvolvimento mediano no sistema de drenagem, devido ao seu índice de densidade de drenagem ser igual a $0,95 \mathrm{~km} / \mathrm{km}^{2}$.

\subsubsection{Hidrogeologia}

Os solos originários do intemperismo da Formação Botucatu formam um pacote de arenito Botucatu. Acima deste pacote é que se desenvolve a maior parte do Ribeirão da Onça. Na maior parte da bacia, a formação Pirambóia está dezenas de metros sob a superfície do solo. Todavia, há indícios de que esta formação esteja aflorante nas proximidades do ribeirão, no centro da bacia (BARRETO, 2006).

Além da Formação Botucatu, a bacia passa, à jusante, sobre sills de diabásio. Estas duas unidades fazem parte do Grupo São Bento, de idade Mesozóica. Há a 
ocorrência regional do Grupo Bauru, que recobre a Formação Botucatu e os supostos basaltos do Grupo São Bento (GOMES, 2008).

Segundo Gomes (2008), estudos comprovam a existência de dois aqüíferos na região estudada: o primeiro representa a passagem de águas de reposição rápidas (chuvas), pouco salinizado; e o segundo representa o Aqüífero Guarani em si. O aqüífero superior corresponde à parte renovável do aqüífero, enquanto que o mais profundo, à parte mais estável.

O solo superficial denominado Sedimento Cenozóico, ocorrente na maior parte do interior do Estado de São Paulo, recobre a bacia do Ribeirão da Onça. Em geral, este solo possui espessura inferior a $10 \mathrm{~m}$, freqüentemente separado da camada subjacente por uma linha de seixos (BORTOLUCCI, 1983). Em função de sua origem, este sedimento é pouco compacto com partículas razoavelmente selecionadas, resultando em uma estrutura bastante porosa. Além disso, há a formação de duas texturas típicas: uma arenosa (predominante na bacia) e outra argilosa (BORTOLUCCI, 1983).

\subsubsection{Meteorologia}

A região onde está localizada a bacia do Ribeirão da Onça possui temperatura média de $20,5^{\circ} \mathrm{C}$, segundo dados obtidos na Estação Climatológica do CRHEA. A classificação climática de Köppen indica que o clima dessa área é subtropical úmido, com chuvas de verão, podendo apresentar variações para o clima tropical úmido com inverno seco (BARRETO, 2006; GOMES, 2008).

A precipitação média anual é da ordem de 1300-1400 mm. Pompêo (1990) apresenta uma média anual regional de longo tempo igual a 1302,4 mm, para a região (BARRETO, 2006; GOMES, 2008). 


\subsubsection{Uso e Ocupação do Solo}

Na Bacia do Ribeirão da Onça, o solo apresenta composição homogênea, com a presença de argilas na região próxima ao exutório da bacia. Na região onde se localiza a bacia há predominância de uso agrário e pecuário, não sendo observadas áreas consideradas pavimentadas e nenhuma área industrial. A cobertura vegetal original dos solos era o cerrado. Atualmente, é composta por pastos, cana de açúcar, laranja, eucalipto, áreas de várzea e culturas de alta rotatividade como soja e amendoim (GOMES, 2008). As figuras de 3 a 8 mostram as diferentes culturas encontradas na região.

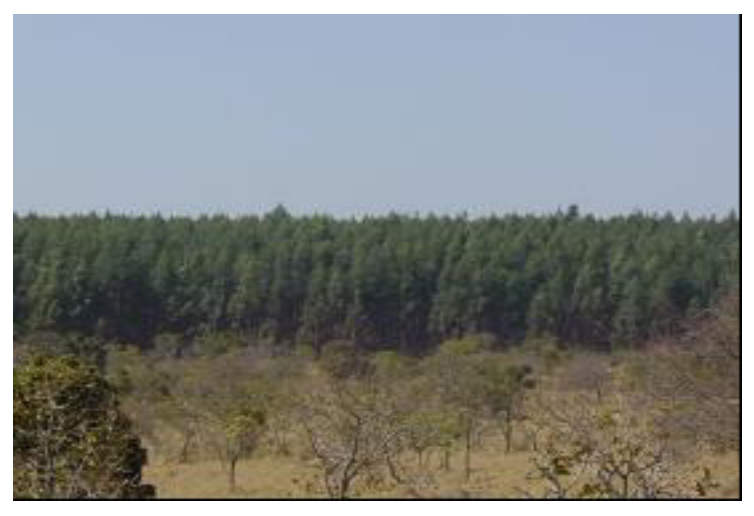

Figura 3: Cultivo de Eucalipto

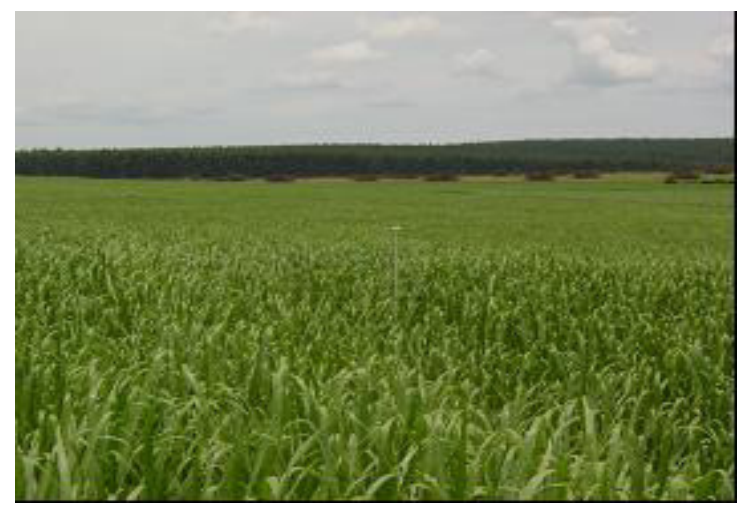

Figura 5: Cultivo de Cana-de- Açúcar

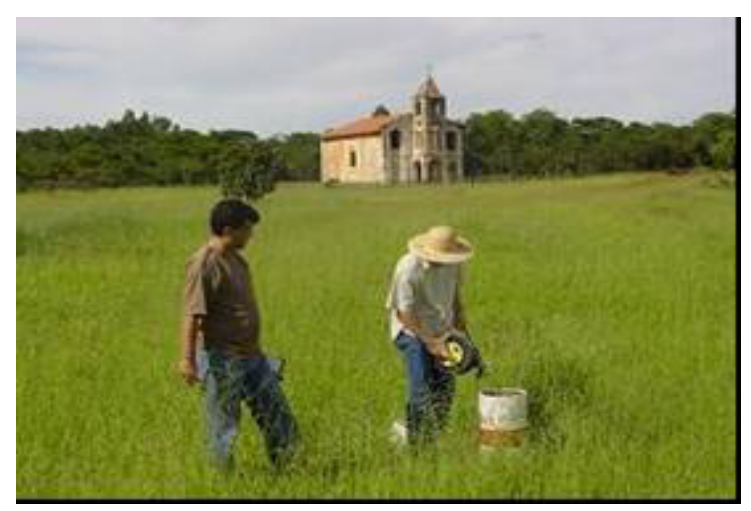

Figura 4: Pastagem

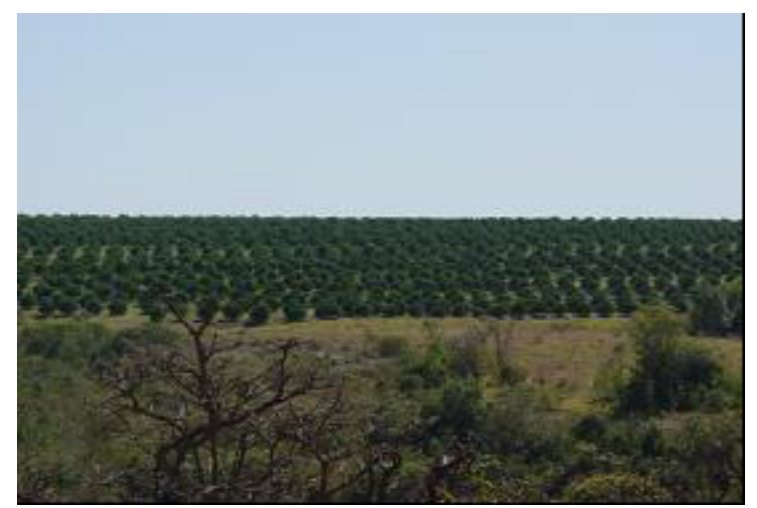

Figura 6: Cultivo de Cítricos 


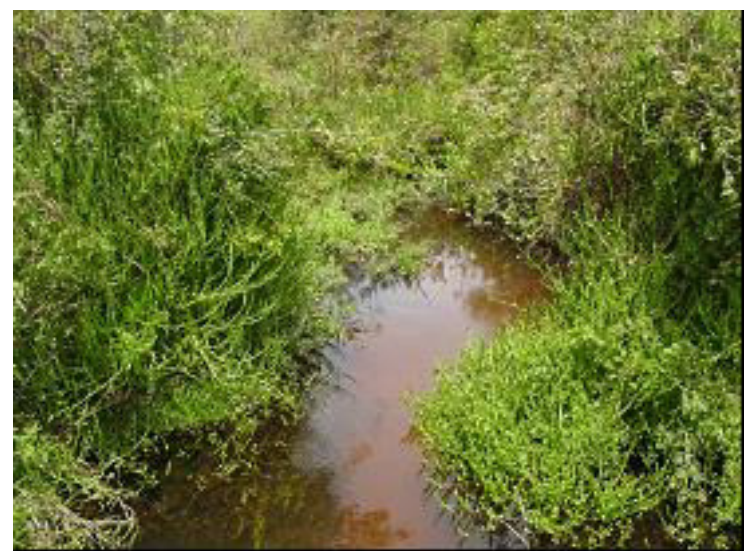

Figura 7: Vegetação Ciliar

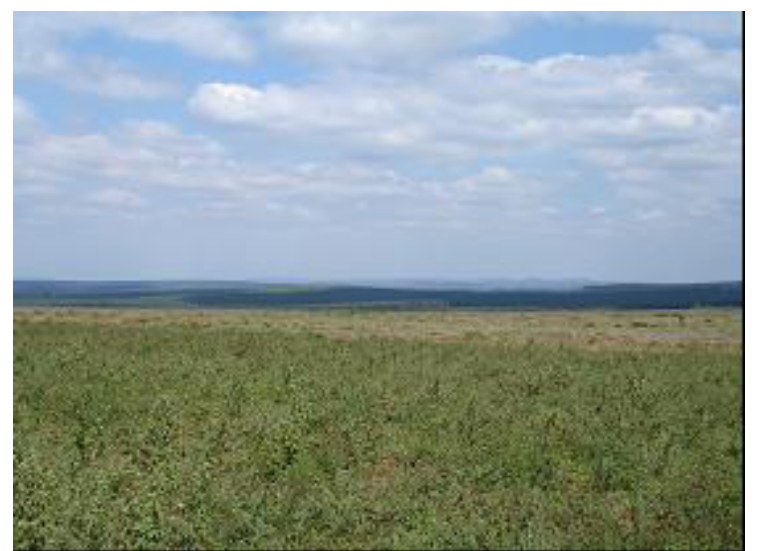

Figura 8: Área semi descoberta

\subsection{DADOS DISPONÍVEIS}

A área que abrange a bacia piloto do Ribeirão da Onça possui 23 (vinte e três) poços de monitoramento, os quais foram construídos em período anterior ao ano de 2004, em áreas de diferentes culturas. O monitoramento do nível d'água é realizado quinzenalmente, com auxílio de um medidor de nível do tipo sensor elétrico com fita milimetrada.

Para o presente estudo foram utilizados dados de 12 dos 23 poços. O descarte de alguns poços ocorreu devido a dois fatores: quatro poços (poços 20, 21, 22 e 23) estão localizados em regiões muito próximas ao curso d'água, os tornando suscetíveis às variações do nível d'água no Ribeirão; e outros sete secaram durante longos períodos (poços $1,2,3,6,7,11$ e 12). A figura 9 mostra a localização dos poços na região da bacia piloto, em que os poços estudados estão destacados.

Como um dos objetivos do presente estudo é a definição da correlação diária entre eventos de precipitação e variação da cota da superfície livre do aqüífero, foi preciso obter dados diários relativos a essa última variável. Portanto, fez-se aplicação de interpolação linear dos dados quinzenais de nível da água subterrânea. 


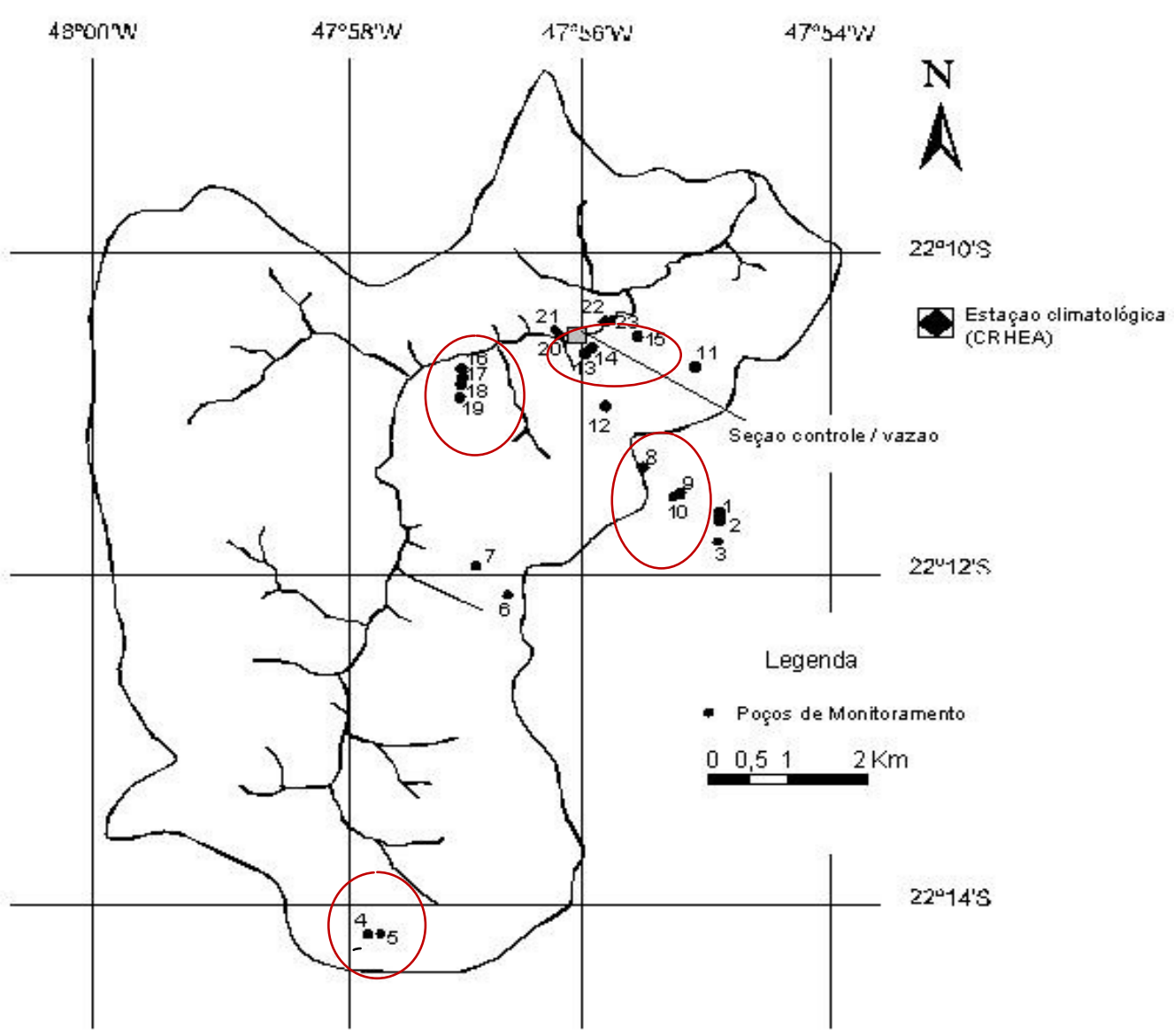

Figura 9: Localização dos poços de monitoramento na Bacia Piloto do Ribeirão da Onça.

Os dados pluviométricos são coletados na Estação Climatológica do CRHEA (Centro de Recursos Hídricos e Ecologia Aplicada) da USP. Esse centro encontra-se localizado a 7km de distância do centro da bacia do Ribeirão da Onça.

Além dos dados piezométricos e pluviométricos, para o estudo foram utilizados valores de porosidade do solo da região e coeficiente de evapotranspiração (Kc). Esses valores foram obtidos de trabalhos anteriormente realizados (BARRETO, 2006; GOMES, 2008). 


\subsection{ESTATÍSTICA DESCRITIVA}

Os gráficos de anos hidrológicos foram construídos a partir de dados mensais de pluviometria e, dados diários de profundidade do nível d'água nos poços monitorados. A partir dos gráficos foi possível detectar padrões de comportamento, como os períodos de estiagem, chuvas e elevações e declínios do nível da superfície livre do aqüífero nos poços.

Calculou-se também o desvio padrão dos dados pluviométricos. Essa medida estatística permite analisar a variabilidade dos dados obtidos, bem como sua dispersão ao longo do ano, em torno dos valores médios da variável estudada. O desvio padrão é definido pela equação:

$$
s=\sqrt{\frac{\sum y^{2}-\left(\sum y\right)^{2} / n}{n-1}}
$$

em que $y$ são os valores da variável analisada e $n$ é o número de dados dessa variável (VIEIRA, 2004).

\subsection{MÉTODOS ESTATÍSTICOS}

Após o tratamento preliminar dos dados, a partir de estatística descritiva, com a qual foi possível detectar padrões iniciais de comportamento do nível d'água nos poços (períodos de elevação e seca) e da precipitação (períodos chuvosos e de estiagem), os dados foram submetidos a estudos estatísticos exploratórios, com o intuito de confirmar as tendências de comportamento das variáveis.

\subsubsection{Análises de Agrupamento}

Os valores obtidos no monitoramento dos poços foram submetidos a análises de agrupamentos, usando o software estatístico SYSTAT (SPSS SCIENCE). Foram 
aplicadas técnicas hierárquicas e divisivas de agrupamento para valores referentes as variações mensais de nível d'água.

Nas técnicas de agrupamento podem ser utilizados atributos para a classificação, ou seja, podem ser incluídos parâmetros ou características dos casos a serem analisados. Assim, neste trabalho, foram usados valores de porosidade, de variação mensal da profundidade da superfície livre (nível) do aqüífero $(\Delta \mathrm{h})$ e de características do uso do solo, através do coeficiente de evapotranspiração $(\mathrm{Kc})$, como atributo para o agrupamento. Esse último parâmetro foi retirado do trabalho de Barreto (2006). Os valores referentes à porosidade foram extraídos do trabalho de Gomes (2008).

Nas técnicas divisivas são usados algoritmos k-means em que as medidas de similaridade entre os grupos são definidas pela Distância Euclidiana (equação 3) entre os centróide dos grupos. Através de softwares estatísticos é computada uma repartição aleatória especificada por um vetor $\mathrm{P}(\mathrm{K}, \mathrm{M})$ em que $\mathrm{M}$ são observações alocadas no grupo K. A partir desse vetor, define-se o centróide inicial para o grupo, ou seja, o valor médio entre todas as variáveis das observações estudadas. A similaridade entre as observações alocadas no agrupamento são medidas pela função erro, definida pela equação 2.

Os valores obtidos pela função-erro definem o número de grupos a serem formados. Quão maior for o número de agrupamentos, menor é o valor do erro.

As técnicas hierárquicas também utilizam a Distância Euclidiana como medida de similaridade. No entanto, utiliza-se a raiz quadrada da distância euclidiana para o calculo da distância entre os grupos (equação 4). 


\subsubsection{Ferramentas Utilizadas para a Análise de Agrupamento}

O software escolhido para o desenvolvimento das técnicas de agrupamento foi o Systat 10, o qual se utiliza de algoritmos para a formação de grupos, sem que sejam definidas as quantidades de grupos a serem formados, nem o numero de observações (casos) que cada um deverá conter. Para o caso dos agrupamentos divisivos o software permite um número de grupos equivalente a 5 , sendo o número de grupos definido pelo pesquisador

Foi escolhido que os grupos fossem exclusivistas, ou seja, uma observação não pode aparecer em mais de um grupo. Tal opção foi feita, pois o objetivo desta etapa é detectar padrões na variação dos poços, através da formação de grupos. Dessa maneira, os poços de monitoramento serão agrupados levando em consideração as características físicas escolhidas: variação da profundidade do nível d'água, porosidade e coeficiente de cultura.

O passo inicial para a formação de grupos, independente da técnica adotada é a padronização dos dados estudados. Isso deve ser feito sempre que as variáveis tiverem valores muito discrepantes. No caso dessa pesquisa, os valores referentes à porosidade são bem mais elevados que os demais atributos. Tal padronização é realizada a partir do cálculo do desvio padrão entre as variáveis (equação 11), a partir da matriz X (12 x 3), em que 12 corresponde ao número de objetos observados (poços de monitoramento) e 3 corresponde as características consideradas no estudo (características físicas da região: porosidade, variação mensal do nível d'água em cada poço e coeficiente de evapotranspiração).

Os dados são dispostos no software (Systat) de maneira semelhante a uma tabela do Excel. A tabela 1 exemplifica essa entrada de dados, para o mês de abril de 2005. 
Para os demais meses foi realizado o mesmo procedimento, ocorrendo modificação apenas nos valores da variação mensal do nível d'água nos poços.

Tabela 1: Entrada de dados referentes ao mês de abril de 2005, utilizados nos agrupamentos

\begin{tabular}{cccc}
\hline Poços & $\mathrm{Kc}$ & Porosidade $(\%)$ & $\Delta \mathrm{h}(\mathrm{m})$ \\
\hline 4 & 0,9 & 15,9 & 0,07 \\
5 & 0,9 & 15,9 & 0,11 \\
8 & 0,8 & 15,1 & 0,09 \\
9 & 1 & 15,1 & 0,12 \\
10 & 1 & 15,1 & 0,11 \\
13 & 0,8 & 15,1 & 0,53 \\
14 & 0,8 & 15,1 & 0,58 \\
15 & 1,04 & 8,5 & 0,02 \\
16 & 0,9 & 12,3 & 0,26 \\
17 & 0,9 & 12,3 & 0,36 \\
18 & 0,9 & 12,3 & 0,46 \\
19 & 0,9 & 12,3 & 0,51 \\
\hline
\end{tabular}

Os valores de porosidade e coeficiente de evapotranspiração são fixos, o que mostra que o cálculo da distância euclidiana só será realizado considerando os valores de variação mensal do nível d'água nos poços monitorados. Contudo, na análise dos resultados, as características físicas serão levadas em consideração, objetivando detectar uma maior influência de uma delas na formação dos grupos.

Escolheu-se para a pesquisa o uso da Distância Euclidiana (equação 3) para definição da distância entre os grupos. Os objetos são agrupados 2 a 2, de acordo com sua maiores semelhanças, e conseqüentemente com a menor distância calculada (equação 4).

\subsection{Técnicas Hierárquicas}

Após realizada a entrada dos dados utilizados no estudo, foi feita a aplicação das técnicas hierárquicas e divisivas. No primeiro caso, os agrupamentos são representados por meio de dendogramas, em que as distâncias expressas em valores 
adimensionais representam o grau de similaridade entre os objetos agrupados. Essas distâncias são calculadas a partir dos resultados da distância euclidiana, entre dois objetos. A partir do software, são realizadas todas as combinações entre os objetos estudados, os menores valores obtidos para a distância (que é adimensional) definem os grupos a serem formados.

Para facilitar o entendimento dessa etapa, consideremos dois poços estudados. Os valores referentes a variação mensal do nível d'água em cada um desses poços será utilizado no cálculo da distância euclidiana (equação 3). Do resultado obtido, extrai-se a raiz quadrada e tem-se, então a distância entre esses dois poços. Tal procedimento é calculado pelo software para todos os pares possíveis de objetos.

A segunda etapa do procedimento consiste na formação de novos grupos contendo mais de dois objetos. Para tal, é utilizada a distância calculada pela equação 4. O processo se repete até resultar em um único grupo contendo todos os objetos (poços monitorados).

O intuito desse método é a definição de grupos, portanto, foi utilizado o critério de parada referente à distância entre esses grupos. Os dendogramas foram analisados e ao se notar um grande salto dos valores das distâncias foram definidos os grupos. Isso quer dizer que se para a formação de 4 grupos a distância obtida foi de 0,3 , enquanto que para a formação de 3 grupos, a distância foi de 0,6 , então tem-se a formação de 4 grupos contendo os poços monitorados.

\subsection{Técnicas Divisivas}

As técnicas divisivas partem de uma decisão do pesquisador quanto ao número de grupos a serem formados. De maneira simplificada, os algoritmos de k-médias $(k$ means) são desenvolvidos a partir do cálculo do erro médio quadrático (equação 2) . O objetivo das técnicas divisivas é formar grupos, em que o erro médio quadrático seja o 
menor possível entre os objetos do grupo. Tem-se inicialmente um vetor $(12,1)$, ou seja, a técnica inicia-se com um único grupo contendo todos os objetos (poços monitorados). De acordo com o cálculo do erro, os objetos são separados em grupos menores, até que cada grupo contenha apenas 1 poço e, consequentemente, o valor do erro seja o menor possível.

Contudo, o software utilizado só permite a partição em, no máximo, 5 grupos. Sendo assim, as possibilidades não são extrapoladas, ou seja, pode ocorrer de existir uma partição de agrupamentos diferente das definidas pelo pesquisador, e que reduzem o erro médio quadrático.

O processo para o desenvolvimento das técnicas divisivas ocorre similarmente às hierárquicas. A única diferença encontra-se na definição prévia do número de grupos a serem formados. Para a pesquisa, definiu-se um número de grupos equivalente a 5 , objetivando obter o menor erro possível. Os resultados não são mostrados por meio de gráficos ou dendogramas, no entanto as distâncias entre o grupo também foram calculadas a partir da distância euclidiana.

\subsubsection{Análise de Séries Temporais}

Os dados coletados, por estarem dispostos em um intervalo de tempo regular, foram tratados como séries temporais. O objetivo desta etapa foi a detecção de padrões (tendências, sazonalidades) tanto dos dados relativos à precipitação quanto aos de mudança no nível d'água no aqüífero.

Nesta etapa da pesquisa foram usados somatórios mensais de pluviometria e variação mensal do nível d'água nos poços monitorados. O período considerado para análise foi de agosto de 2004 até setembro de 2008. Foi utilizado o software SYSTAT para analisar a autocorrelação das séries temporais de variação do nível d'água e 
precipitação. Os gráficos gerados contendo os valores de autocorrelação, denominados correlogramas, permitem verificar tendências de variações ao longo dos quatro anos estudados, bem como comparar a variação do nível nos diferentes poços monitorados, os quais se encontram em culturas de solo e a profundidades diferentes.

\subsubsection{Ferramentas Utilizadas para Análise de Séries Temporais}

Para alcançar os objetivos propostos no trabalho foram utilizadas ferramentas básicas do software estatístico escolhido. Optou-se por trabalhar no domínio tempo para verificar o comportamento dos dados das variáveis estudadas ao longo do período de tempo definido.

Realizou-se, a partir do software, o cálculo das autocorrelações dos dados coletados. Como citado na revisão, a autocorrelação mostra quão dependentes são os valores de uma mesma variável. Trata-se, portanto, de um método auto-regressivo. A primeira autocorrelação é calculada a partir do coeficiente de correlação de Pearson (VIEIRA, 2004), pela equação:

$$
r=\frac{\sum x y-1 / n \sum x \sum y}{\sqrt{\left[\sum x^{2}-\frac{1}{n\left(\sum x\right)^{2}}\right]\left[\sum y^{2}-\frac{1}{n\left(\sum y\right)^{2}}\right]}}
$$

Esse coeficiente é calculado utilizando-se duas variáveis, no entanto no caso das séries temporais, faz-se o uso de apenas uma variável. Dessa maneira, o calculo é feito entre a série de dados $\left(\mathrm{y}_{1}, \mathrm{y}_{2}, \mathrm{y}_{3}, \ldots, \mathrm{y}_{\mathrm{n}}\right)$ e a mesma série deslocada de uma observação $\left(\mathrm{y}_{2}, \mathrm{y}_{3}, \ldots, \mathrm{y}_{\mathrm{n}-1}\right)$, ou seja, aplicando as séries na equação acima, considera-se $x$ como a série inicial $\left(\mathrm{y}_{1}, \mathrm{y}_{2}, \mathrm{y}_{3}, \ldots, \mathrm{y}_{\mathrm{n}}\right)$ e y como a série deslocada de uma observação $\left(\mathrm{y}_{2}, \mathrm{y}_{3}, \ldots, \mathrm{y}_{\mathrm{n}}\right.$ 1).

A partir do primeiro coeficiente de correlação são calculadas as autocorrelações de acordo com a equação de autocorrelação: 


$$
r_{k}=\frac{\sum_{t}^{n-k}\left(x_{t}-X_{1}\right)\left(x_{t+1}-X_{2}\right)}{\sqrt{\sum_{t=1}^{n-k}\left(x_{t}-X_{1}\right)^{2}}\left(x_{t+1}-X_{2}\right)^{2}}
$$

em que $\mathrm{X}_{1}$ e $\mathrm{X}_{2}$ são as médias amostrais das séries $x_{t}=1, \ldots, \mathrm{n}-1$ e $x_{t+1}=2, \ldots, \mathrm{n}$ e, $k$ é o deslocamento da série, aqui considerou-se $k=48$, já que foram utilizados valores mensais das duas variáveis estudadas. A autocorrelação também permite verificar a sazonalidade das séries, uma vez que os valores calculados são expostos no gráfico em função da defasagem (intervalo de tempo, no caso dessa pesquisa, número de meses).

Os correlogramas contêm seqüências de barras que mostram as correlações obtidas. Assim a primeira barra é a correlação de primeira ordem, gerada pelo coeficiente de correlação de Pearson. Cada valor obtido, em função da defasagem, mostra quão forte os dados estão correlacionados. Além disso, mostra que os valores posteriores podem ser previstos pelos anteriores. Sendo assim, é possível definir os períodos de mudanças no nível d'água nos poços monitorados.

\subsubsection{Análises de Correlação}

A etapa de estudo da correlação tem por objetivo principal verificar a relação, ou possível associação, entre as duas variáveis estudadas: precipitação e variação da profundidade da superfície livre do aqüífero. Para isso, optou-se pelo uso do coeficiente de correlação de Pearson, por ser o coeficiente mais utilizado em estudos estatísticos em Hidrologia.

Como primeiro passo da etapa, fez-se o cálculo de correlação entre as variações mensais do nível d'água nos poços monitorados. Utilizou-se o coeficiente de correlação de Pearson (equação 5), considerando como variáveis pares de poços. Isso quer dizer que os poços foram comparados 2 a 2, até que se obtivesse os coeficientes de correlação entre todos os poços. 
A partir da análise de gráficos contendo a variação do nível d'água no aqüífero e a variação pluviométrica, ao longo dos quatros anos hidrológicos, notou-se que os dois fenômenos não ocorrem simultaneamente. Isso significa que um evento de precipitação não gera, de maneira imediata, uma elevação do nível do aqüífero. Por isso foram realizados testes, detalhados a seguir, para determinar o melhor coeficiente de correlação, bem como delinear o comportamento dos dois fenômenos.

\subsubsection{Correlação Mensal}

Inicialmente, o objetivo da pesquisa era definir o índice de correlação entre o nível d'água no aqüífero e a precipitação utilizando-se valores diários dos mesmos, coletados ao longo de quatro anos. No entanto, as variações diárias do nível d'água são pequenas (geralmente, em torno de $0,01 \mathrm{~m}$ ) e há vários períodos (dias) em que não ocorrem eventos de chuva. Desse modo, optou-se pelo cálculo do coeficiente de correlação de Pearson (equação 5), utilizando como variáveis valores de precipitações acumuladas mensalmente e variações mensais do nível d'água em cada poço monitorado.

\subsubsection{Correlação entre Variação do Nível d'Água e Precipitação Acumulada (em periodos de elevação do nível)}

Nesta etapa utilizou-se como base a metodologia proposta no estudo de Jan, Chen e Lo (2006), em que o coeficiente de correlação é obtido a partir da relação entre o incremento corrigido do nível d'água nos poços e a precipitação acumulada. $\mathrm{O}$ incremento corrigido do nível d'água é equivalente a variação $\Delta h$ utilizada no método WTF, ou seja, é a diferença entre o pico da curva ascendente e o ponto mais baixo da curva de recessão antecedente extrapolada até o instante do pico. Essa curva extrapolada é a trajetória do linigrama do poço de monitoramento na ausência da elevação do nível d'água, como mostra a figura 10. 


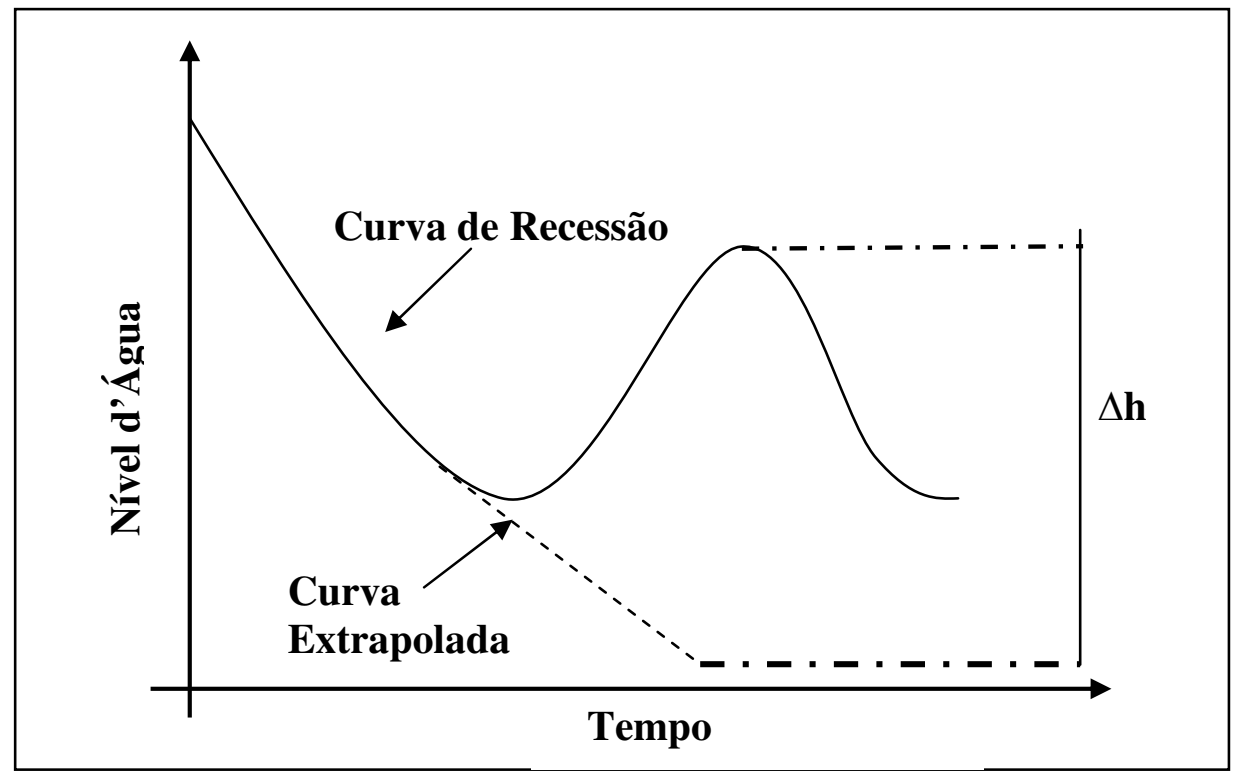

Figura 10: Variação do nível d'água em um poço corrigida, segundo método WTF Fonte: Adaptado de Healy e Cook (2002)

As curvas de recessão foram obtidas do trabalho de Gomes (2008), que se utilizou de equações exponenciais para a extrapolação. Os valores referentes à precipitação foram calculados como o somatório dos eventos diários de precipitação do período equivalente ao final da curva de recessão até o último dia em que houve elevação do nível d'água. Os valores de $\Delta \mathrm{h}$ obtidos pelas curvas de recessão foram corrigidos multiplicando-os pela porosidade da região onde cada poço está localizado.

A partir dos valores de precipitação acumulada e variação do nível d'água, realizou-se o cálculo do coeficiente de correlação (equação 5) para cada poço. Os resultados obtidos serão comparados com os valores encontrados nos testes anteriores.

\subsubsection{Estimativa da Defasagem entre Precipitação e Variação do Nível d’Água}

Para esta etapa propôs-se definir a defasagem entre um evento de precipitação e a elevação do nível d'água em um poço de monitoramento. Para isso, foram consideradas apenas as variações diárias do nível d'água nos poços de monitoramento, em períodos em que houve elevação. Foram utilizados valores de precipitações acumuladas de $2,3,4,5,6,7,10,15$ e 20 dias anteriores ao início do período de 
elevação do nível d'água. O cálculo foi realizado de maneira que o último valor de precipitação acumulada também seja defasado. Isso significa que para uma precipitação acumulada dois dias antes do início do período de elevação do nível d'água, o último valor a ser considerado será de dois dias antes do último dia em que ocorreu a elevação. A figura 11 apresenta um gráfico esquemático para explicar o procedimento.

O uso de diferentes intervalos de tempo permitirá a obtenção de diferentes coeficientes de correlação e, conseqüentemente, uma comparação entre tais valores. Os valores mais elevados de correlação mostrarão, portanto, a defasagem entre os eventos hidrológicos estudados.

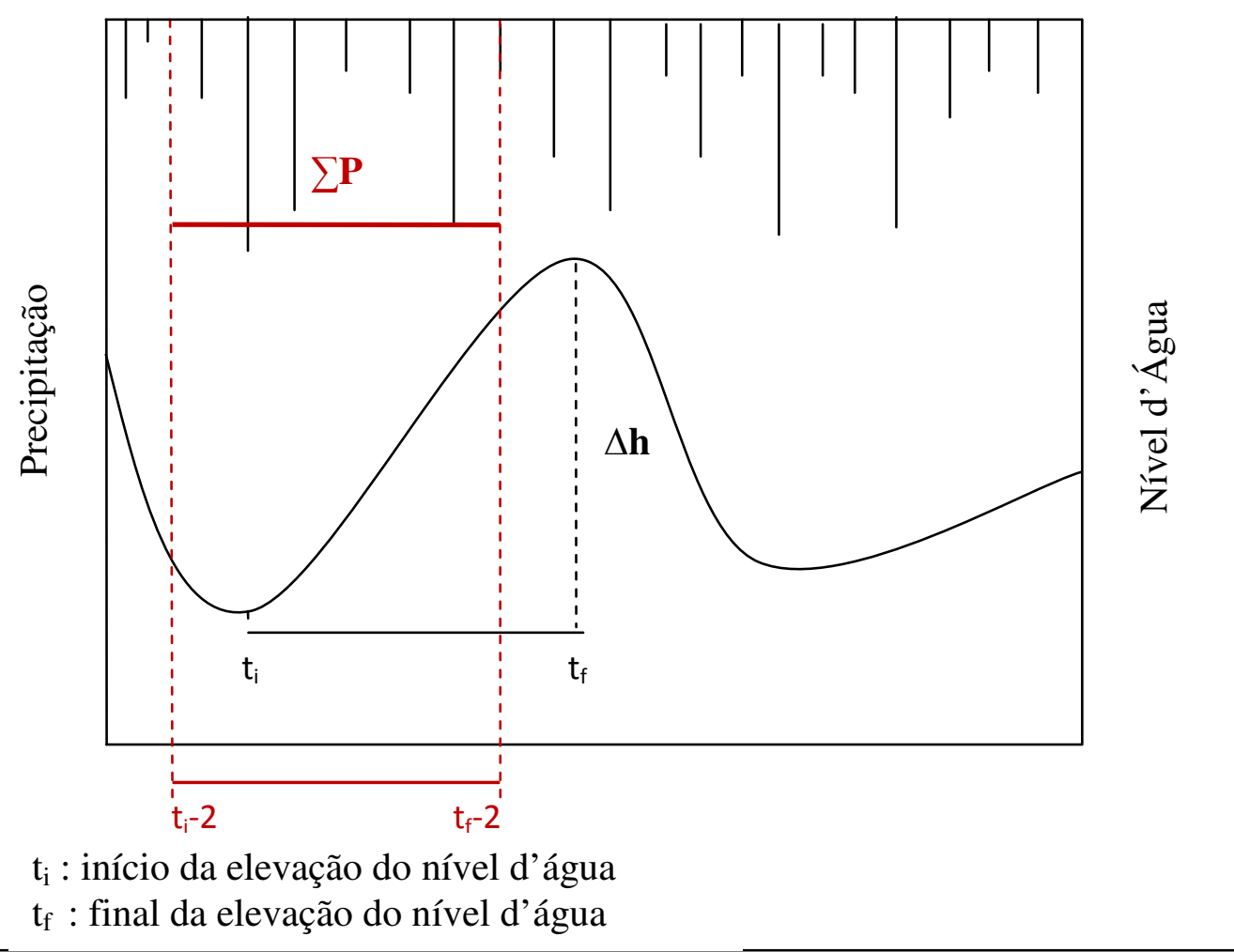

Figura 11: Gráfico esquemático do procedimento para cálculo da defasagem entre precipitação e elevação do nível d'água nos poços monitorados. 


\section{RESULTADOS E DISCUSSÃO}

\subsection{DISTRIBUIÇÃO PLUVIOMÉTRICA}

A tabela 2 mostra os valores mensais de pluviometria na área estudada, no período de outubro de 2004 a setembro de 2008. Como já citado, os dados foram coletados na Estação Climatológica do Centro de Recursos Hídricos e Ecologia Aplicada (CRHEA-USP), localizada nas proximidades da bacia do Ribeirão da Onça, nas coordenadas $22^{\circ} 10^{\prime} 13,7^{\prime} ' \mathrm{~S}$ e $47^{\circ} 53^{\prime} 55^{\prime}, \mathrm{W}$.

Tabela 2: Pluviometria mensal nos anos hidrológicos estudados.

\begin{tabular}{l|c|c|c|c|c|c}
\hline & Out/04 - & Out/05 - & Out/06 - & Out/07 - & Média & Desvio Padrão \\
& Set/05 & Set/06 & Set/07 & Set/08 & & \\
\hline Outubro & 127,3 & 84,80 & 115,1 & 129,8 & 124,9 & 6,6 \\
Novembro & 167,7 & 100,7 & 100,7 & 194,2 & 157,6 & 39,9 \\
Dezembro & 182,5 & 225,0 & 361,7 & 125,9 & 223,8 & 100,5 \\
Janeiro & 542,3 & 180,7 & 381,3 & 270,4 & 343,7 & 155,8 \\
Fevereiro & 69,0 & 263,0 & 244,9 & 157,0 & 183,5 & 89,3 \\
Março & 155,2 & 162,5 & 93,2 & 228,4 & 159,8 & 55,3 \\
Abril & 13,1 & 24,4 & 95,6 & 98,6 & 57,9 & 45,5 \\
Maio & 87,9 & 15,7 & 62,0 & 43,7 & 52,3 & 30,4 \\
Junho & 41,5 & 18,3 & 13,7 & 43,9 & 29,4 & 15,6 \\
Julho & 4,3 & 34,3 & 161,4 & 0,0 & 50,0 & 75,8 \\
Agosto & 16,1 & 15,7 & 0,0 & 63,0 & 23,7 & 27,3 \\
Setembro & 85,0 & 57,4 & 0,7 & 38,5 & 45,4 & 35,4 \\
\hline TOTAL ANUAL & $\mathbf{1 4 9 1 , 4}$ & $\mathbf{1 2 9 2}$ & $\mathbf{1 6 3 0 , 3}$ & $\mathbf{1 3 9 3 , 4}$ & & \\
\hline
\end{tabular}

Ao analisar a tabela, é possível perceber que o ano hidrológico de maior pluviometria foi o de outubro de 2006 a setembro de 2007. O ano de 2004/2005 teve a segunda maior taxa pluviométrica anual, sendo, aproximadamente, 10\% menor em comparação a 2006/2007. O ano hidrológico de 2005/2006 mostrou-se como o de menor pluviometria, estando $17 \%$ abaixo de 2006/2007. O ano de 2007/2008 teve a taxa pluviométrica anual $15 \%$ menor do que o ano de maior pluviometria. Percebe-se a diminuição das taxas pluviométricas relativas aos meses de setembro/2007 a 
fevereiro/2008, se comparado aos anos anteriores. Por outro lado, no período correspondente que vai de março a agosto/2008 ocorreu um aumento das taxas mensais em relação aos mesmos períodos para os anos anteriores, com exceção do mês de julho, em que não ocorreu nenhum fenômeno de chuva. Os meses de março e agosto do ano de 2008 registraram os maiores valores de precipitação ao longo dos quatro anos estudados, comparando com os mesmos meses dos anos anteriores.

O mês de janeiro de 2005 foi o de maior taxa pluviométrica, atingindo 542,3 mm. Quando comparado ao mesmo mês do ano seguinte percebe-se uma diminuição da taxa em, aproximadamente, 67\%. Os demais anos também se mostram consideravelmente menores. Em 2007, o valor da pluviometria, em Janeiro, foi $30 \%$ menor que 2005, e, em 2008, esse valor foi 50\% menor. Assim, para os meses de Janeiro dos anos estudados, o ano de 2005 foi anormal quanto à taxa de pluviometria.

Nos gráficos das figuras 12 e 13 são mostradas as distribuições pluviométricas mensais e anuais observadas no período de análise. 


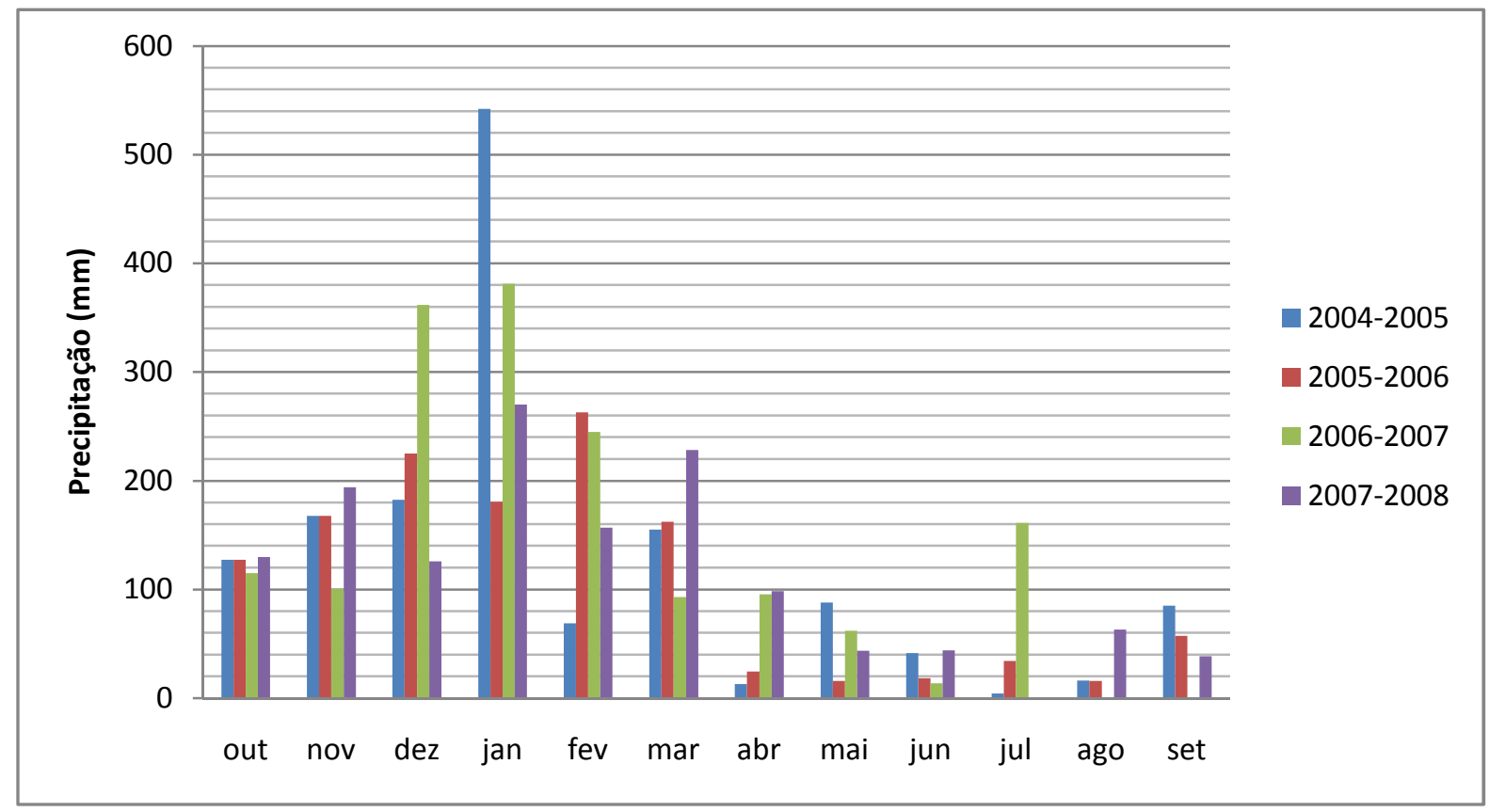

Figura 12: Distribuição mensal pluviométrica para os anos hidrológicos estudados

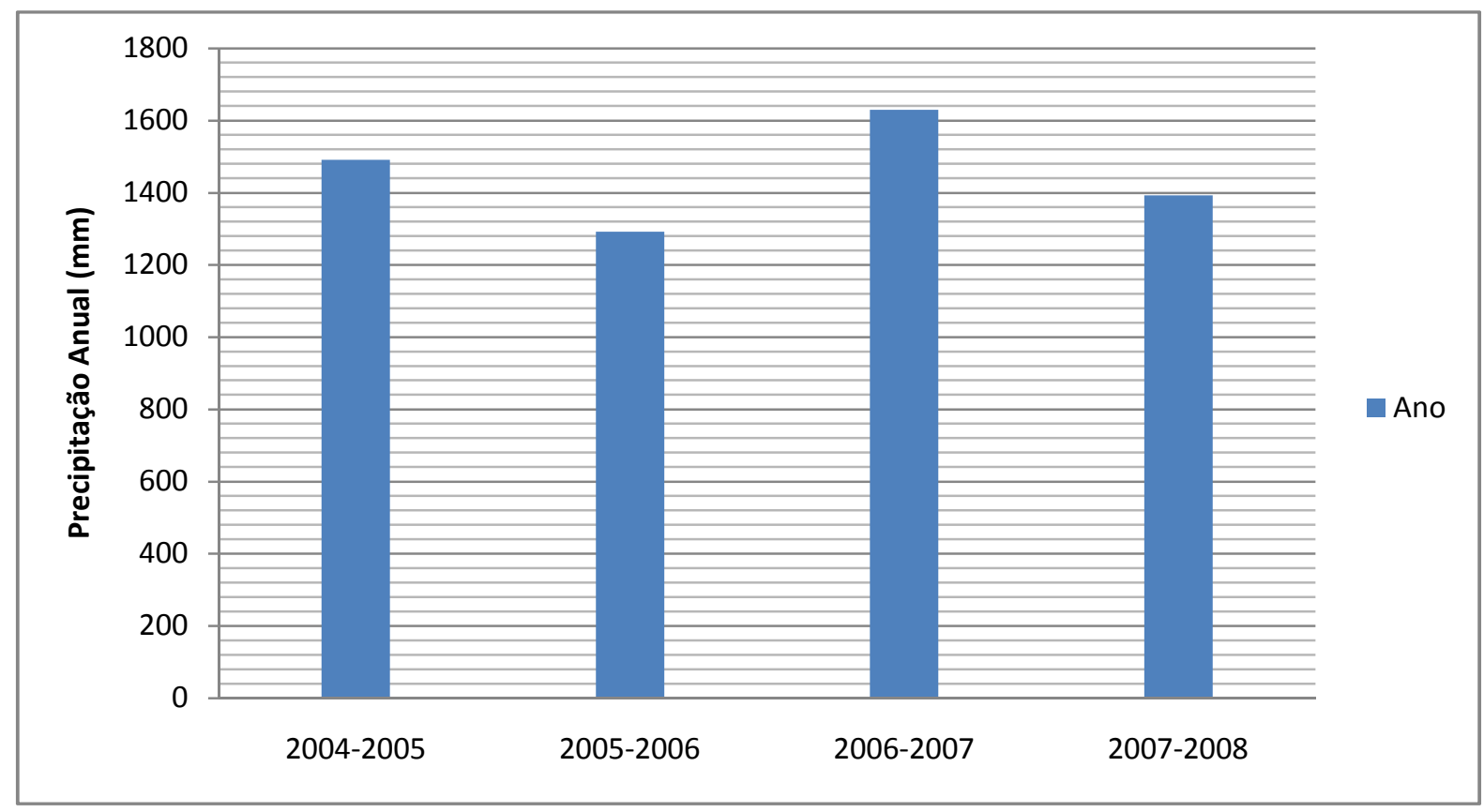

Figura 13: Precipitação anual para o período de 2004 a 2008.

A análise dos anos estudados evidencia a existência de um padrão de sazonalidade nos fenômenos de precipitação na região, que é marcada por períodos distintos de alta e baixa pluviometria. A partir do mês de outubro há o início das chuvas, estendendo-se até março. Os picos ocorrem nos meses de novembro, dezembro e janeiro, com ênfase para o mês de janeiro de 2005, em que foi constatada a maior taxa 
pluviométrica (542 mm) de todos os anos estudados. Contudo, GOMES (2008) ressalta que há uma discrepância entre os valores mensais de janeiro e fevereiro do ano de 2005 , quando comparados à média histórica mensal, indicada por um adiantamento das chuvas ocorrentes em fevereiro para o mês de janeiro. O decréscimo das taxas de precipitação ocorre a partir de abril e estende-se até setembro. Para os anos analisados, apenas em agosto de 2007 e julho de 2008 não ocorreram chuvas. No entanto em julho de 2007, houve uma taxa pluviométrica considerável $(161,4 \mathrm{~mm})$ e, em setembro deste mesmo ano, o valor foi consideravelmente baixo $(0,7 \mathrm{~mm})$.

Há uma distribuição homogênea das chuvas ao longo dos meses. Nos meses de maio, junho e julho, para os quatro anos hidrológicos, as taxas de precipitação são baixas. A exceção ocorre nos meses de julho e agosto de 2007, em que foi detectada a ocorrência de fortes chuvas em poucos dias (houve precipitação em apenas 4 dias do mês), o que reflete sua má distribuição. Assim, apesar da sazonalidade que caracteriza a pluviometria da região, há uma grande variação nos períodos chuvosos ao longo dos anos, marcados pela ocorrência de fortes chuvas, seguidas por períodos (dias e/ou semanas) secos.

\subsection{VARIAÇÃO DO NÍVEL D’ÁGUA NOS POÇOS MONITORADOS}

O estudo contemplou níveis d'água em 12 poços de monitoramento, no período de setembro/2004 a agosto/2008. O poço com menor profundidade do nível d'água (5,08 $\mathrm{m})$ encontra-se localizado em área de pastagem, enquanto que o de maior profundidade do nível d'água $(22,72 \mathrm{~m})$ está localizado em área de cultivo de cítricos (laranja, limão). Os gráficos referentes à variação dos níveis d'água ao longo dos quatro anos, em função das taxas de precipitação, encontram-se no apêndice A do trabalho. 
A análise dos gráficos da profundidade do nível d'água, dos anos de setembro/2004 a agosto/2008 mostra que há uma grande variabilidade nos níveis d'água dos poços monitorados. Para os gráficos foram utilizados as variações diárias do nível d' água (m) de cada poço.

Os poços 4 e 5 estão localizados em área de pastagem. A profundidade do nível d'água mínima do poço 4 foi de $16,51 \mathrm{~m}$ e a máxima foi de $18,40 \mathrm{~m}$, enquanto que no poço 5 a profundidade do nível d'água mínima foi de 5,27 m e a máxima de 8,29 $\mathrm{m}$. A variação dos niveis d'água desses poços parece acompanhar a sazonalidade da pluviometria da região, já que é possivel perceber que há um aumento do nivel da água nos meses mais chuvosos (dezembro a fevereiro). Os poços 16, 17, 18 e 19 estão localizados em área de pastagem e também acompanham a ocorrência das chuvas na região. Os níveis d'água nesses poços variaram, ao longo dos quatro anos estudados, com valores mínimos e máximos de 3,62 m e 6,24 m; 8,37 m e 12,86 m; 10,57 m e $16,40 \mathrm{~m} ; 11,67 \mathrm{~m}$ e $17,15 \mathrm{~m}$, respectivamente.

O poço 8 está localizado na área de cultivo de cítricos. Contudo, no segundo semestre do ano de 2006 houve uma mudança na cultura da região e, passou-se a cultivar cana-de-açúcar na área em que está localizado esse poço. A profundidade mínima detectada no poço 8 foi de $19,79 \mathrm{~m}$, enquanto a máxima foi de 25,55 $\mathrm{m}$. Os poços 13 e 14 também estão localizados em região de cultivo de cítricos e acompanham a sazonalidades das chuvas. Assim, em períodos chuvosos (dezembro a fevereiro) houve uma elevação do nível, enquanto que nos períodos mais secos (abril a setembro) ocorreu uma diminuição do nível d'água desses poços. O nível d'água no poço 13 atingiu a profundidade mínima de 6,04 m e a máxima de 11,04 m, já o nível d'água no poço 14 atingiu a profundidade mínima de 4,00 m e a máxima de 10,47 m. 
Em área de cultivo de eucalipto foram monitorados os poços 9 e 10, cujos níveis d'água atingiram as profundidades mínimas e máximas de 19,52 m e 23,94 m e, 18,48 m e 21,06 m, respectivamente. Nos poços dessa áreas não foi possivel detectar um padrão de sazonalidade na variação do nível d'água. Contudo, analisando as médias mensais, é possível observar que nos meses mais secos houve uma pequena elevação dos níveis d'água nos poços 9 e 10. Cabe ressaltar que no final do ano de 2007 houve o corte do eucalipto. Tal situação coincidiu com o início do período de elevação do nível d'água nos poços, indicando que há forte influência da cultura no processo de recarga de aquíferos.

Na região de cultivo de cana-de-açúcar foi monitorado o poço 15 . Nesta área também ocorreu a mudança da cultura, no segundo semestre de 2006, que passou a ser de cítricos. O poço 15 apresentou variação do nível d'água acompanhando a sazonalidade das chuvas; o nível d'água atingiu profundidade mínima de 6,30 m e máxima de 9,47 m.

De maneira geral, percebe-se que os poços acompanham a sazonalidade da precipitação, ou seja, em períodos chuvosos há uma elevação do nível do aquifero, enquanto que em períodos de estiagem esses níveis sofrem um declínio (aumento de profundidade). As variações de nível d'água nos poços 9 e 10 não acompanham a sazonalidade das chuvas, uma vez que só houve elevação do nível a partir do ano de 2007. Esse fato indica que culturas de eucalipto podem influenciar no processo de infiltração da água no solo e, portanto, na recarga das água subterrâneas.

Após o estudo estatístico inicial, os dados coletados foram submetidos a análise de séries temporais, objetivando definir a autocorrelação (r) dos valores obtidos. 


\subsection{AGRUPAMENTOS DOS POÇOS MONITORADOS}

O objetivo de aplicar técnicas de agrupamento foi o de detectar a formação de classes de poços de monitoramento a partir de atributos comuns (características físicas da região estudada). Assim, foram considerados valores de coeficiente de evapotranspiração $(\mathrm{Kc})$, porosidade e variação da profundidade do nível d'água no aqüífero (variação mensal observada em cada poço), os quais foram obtidos dos trabalhos de BARRETO (2006) e GOMES (2008).

Foram utilizadas técnicas hierárquicas e divisivas para o agrupamento. Inicialmente, as três variáveis, variação da profundidade do nível d'água, porosidade e coeficiente de cultura, foram utilizadas como atributos para o agrupamento. Foram realizados agrupamentos mensais, com o objetivo de verificar mudanças nos agrupamentos ao longo do ano. Os valores de porosidade e coeficiente de cultura foram considerados fixos. Para os agrupamentos mensais, o único valor modificado mensalmente foi a variação do nível d’água. Dessa maneira, as distâncias euclidianas entre os objetos (poços) foram calculadas utilizando-se de valores mensais da variação do nível d'água em cada poço.

\subsubsection{Agrupamentos Hierárquicos}

As distâncias euclidianas foram calculadas a partir das equações 3 e 4, usando o software estatístico SYSTAT. Para cada mês estudado, gerou-se um dendograma, contudo estes se mostraram idênticos, o que possibilitou o uso de apenas um dendograma para representar os demais agrupamentos mensais.

No dendograma da figura 14 é mostrado o agrupamento dos poços, de acordo com o cálculo de distância euclidiana da variação mensal do nível d'água nos poços monitorados. 


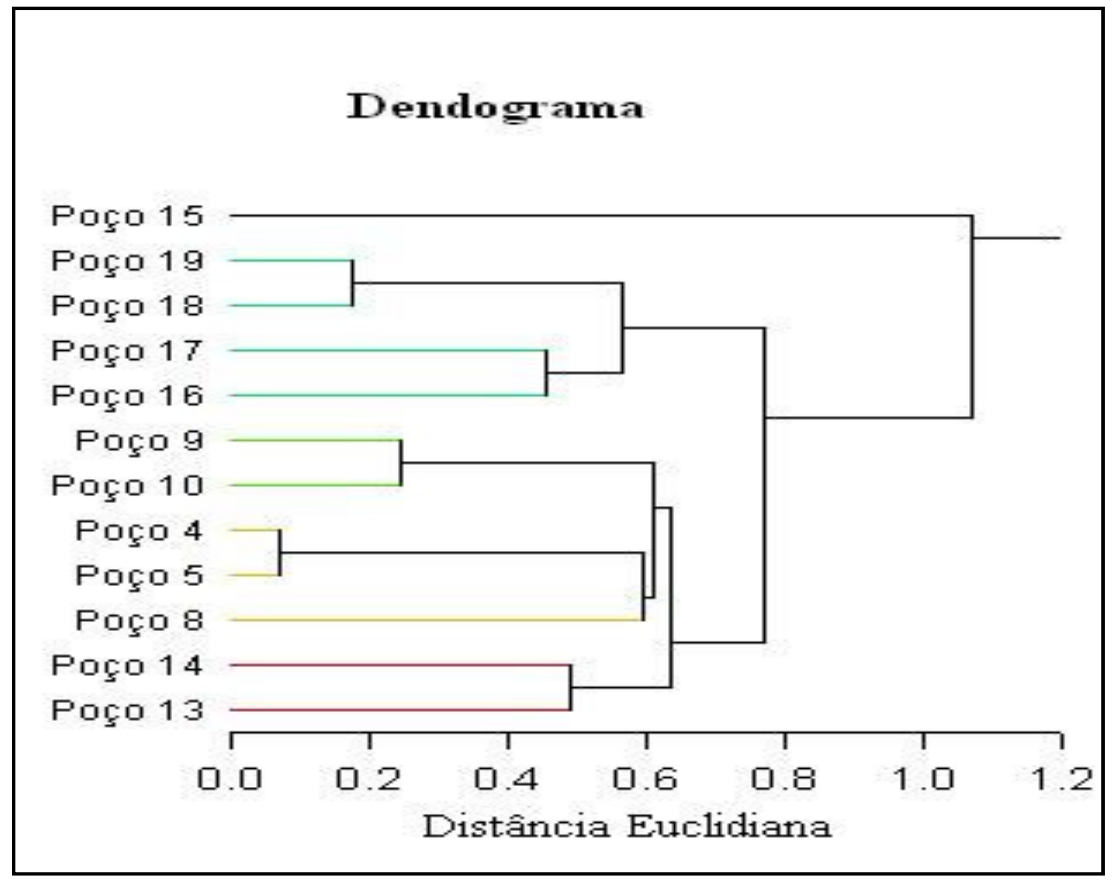

Figura 14: Dendograma de agrupamento para os poços monitorados, no período de setembro de 2004 a julho de 2006.

A tabela 3 apresenta os valores obtidos para as distâncias euclidianas da variação mensal do nível d'água e os poços agrupados de acordo com essas medidas.

Tabela 3: Sequiência de agrupamentos de acordo com o cálculo da distância euclidiana, para o período de setembro de 2004 a julho de 2006.

\begin{tabular}{c|l|c|c}
\hline Grupo & Grupo & $\begin{array}{l}\text { Distância } \\
\text { Euclidiana }\end{array}$ & $\begin{array}{l}\text { Número de membros } \\
\text { no novo grupo }\end{array}$ \\
\hline Poço 5 & Poço 4 & 0,071 & 2 \\
Poço 19 & Poço 18 & 0,176 & 2 \\
Poço 10 & Poço 9 & 0,247 & 2 \\
Poço 17 & Poço 16 & 0,458 & 2 \\
Poço 14 & Poço 13 & 0,494 & 2 \\
Poço 17 & Poço 19 & 0,564 & 4 \\
Poço 5 & Poço 8 & 0,595 & 3 \\
Poço 10 & Poço 5 & 0,611 & 5 \\
Poço 10 & Poço 14 & 0,635 & 7 \\
Poço 17 & Poço 10 & 0,774 & 11 \\
Poço 15 & Poço 17 & 1,074 & 12 \\
\hline
\end{tabular}

Após os agrupamentos iniciais, contendo todas as variáveis escolhidas, optou-se por testar agrupamentos com duas variáveis, isto é, foram realizados agrupamentos 
incluindo porosidade e variação da profundidade do nível do aqüífero; porosidade e coeficiente de cultura; coeficiente de cultura e variação da profundidade do nível do aqüífero; e somente variação mensal do nível d'água nos poços. O intuito desses testes foi verificar modificações na formação dos grupos. Caso ocorressem, seria possível supor que um dos atributos escolhidos para esse estudo possui maior influência na variação do nível do aqüífero. Todavia, os testes resultaram em agrupamentos semelhantes, o que indica que não há uma única variável responsável pela divisão dos poços em grupos.

Em agosto de 2006 ocorreu mudança de cultura em áreas onde estão localizados os poços 8 e 15. Dessa maneira, foi realizado um novo agrupamento, com os valores de coeficiente de evapotranspiração modificados. O poço 8 passou a estar localizado em região de cultivo de cana-de-açúcar, enquanto que o poço 15 localiza-se, desde 2006, em região de cultivo de cítricos. O dendograma da figura 12 apresenta o novo agrupamento.

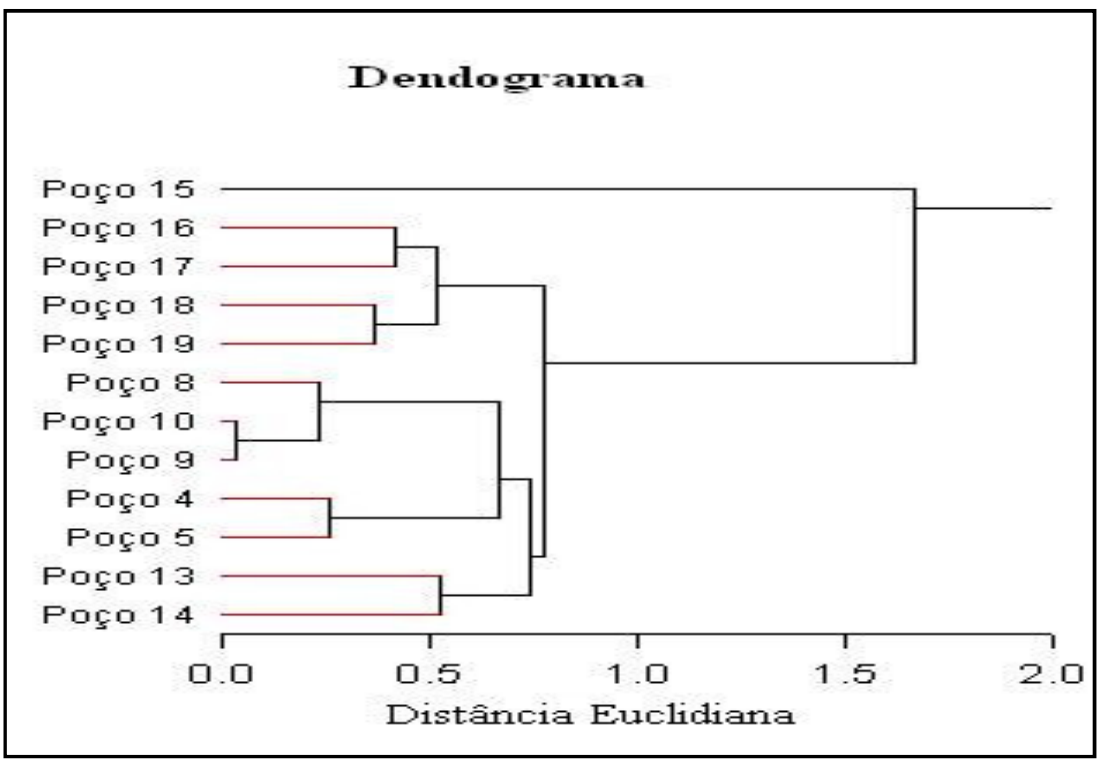

Figura 15: Dendograma de agrupamento dos poços monitorados para o período de agosto de 2006 a agosto de 2008. 
Tabela 4: Seqüência de agrupamento de acordo com o cálculo da distância euclidiana, para o período de agosto de 2006 a setembro de 2008.

\begin{tabular}{l|l|l|c}
\hline Grupo & Grupo & $\begin{array}{c}\text { Distância } \\
\text { Euclidiana }\end{array}$ & $\begin{array}{c}\text { Número de membros } \\
\text { no novo grupo }\end{array}$ \\
\hline Poço 10 & Poço 9 & 0,038 & 2 \\
Poço 8 & Poço 10 & 0,240 & 3 \\
Poço 5 & Poço 4 & 0,264 & 2 \\
Poço 19 & Poço 18 & 0,365 & 2 \\
Poço 17 & Poço 16 & 0,416 & 2 \\
Poço 17 & Poço 19 & 0,516 & 4 \\
Poço 14 & Poço 13 & 0,529 & 2 \\
Poço 8 & Poço 5 & 0,673 & 5 \\
Poço 8 & Poço 14 & 0,740 & 7 \\
Poço 17 & Poço 8 & 0,776 & 11 \\
Poço 17 & Poço 15 & 1,666 & 12 \\
\hline
\end{tabular}

Comparando os dois dendogramas gerados pelas técnicas de agrupamento, notase que não há grandes saltos entre as distâncias euclidianas obtidas. Segundo a revisão bibliográfica, o critério para definição dos agrupamentos, nas técnicas hierárquicas, é o salto do valor da distância euclidiana. Dessa maneira, para análise dos resultados, definiu-se a formação de cinco grupos, os quais foram gerados com uma distância euclidiana no valor de 0,6 .

\subsubsection{Agrupamentos Divisivos}

Os agrupamentos divisivos, realizados a partir do desenvolvimento de algoritmos $k$-means (para tal, fez-se uso do software estatístico Systat) estão apresentados nas tabelas 5 e 6 . Da mesma maneira que para as técnicas hierárquicas, realizou-se o agrupamento mensal dos poços monitorados. A medida de similaridade adotada foi a distância euclidiana, para variações mensais do nível d'água em cada poço. 
Tabela 5: Agrupamento dos poços monitorados, a partir de técnicas divisivas, para o período de setembro de 2004 a julho de 2006.

\begin{tabular}{lr|rr|rr|lr|rr}
\hline Grupo & Distância & Grupo & Distância & Grupo & Distância & Grupo & Distância & Grupo & Distância \\
\hline Poço 5 & 0,61 & Poço 16 & 0,26 & Poço 18 & 0,18 & Poço 4 & 0,4 & Poço 15 & 0 \\
Poço 8 & 0,18 & Poço 17 & 0,26 & Poço 19 & 0,18 & Poço 9 & 0,21 & & \\
Poço 13 & 0,32 & & & & & Poço 10 & 0,23 & & \\
Poço 14 & 0,15 & & & & & & & & \\
\hline
\end{tabular}

Tabela 6: Agrupamento dos poços monitorados, a partir de técnicas divisivas, para o período de agosto de 2006 a agosto de 2008.

\begin{tabular}{|c|c|c|c|c|c|c|c|c|c|}
\hline Grupo & Distância & Grupo & Distância & Grupo & Distância & Grupo & Distância & Grupo & Distância \\
\hline Poço 4 & 0,43 & Poço 18 & 0,18 & Poço 15 & 0 & Poço 13 & 0,26 & Poço 16 & 0,21 \\
\hline Poço 5 & 0,59 & Poço 19 & 0,18 & & & Poço 14 & 0,26 & Poço 17 & 0,21 \\
\hline Poço 8 & 0,49 & & & & & & & & \\
\hline Poço 9 & 0,25 & & & & & & & & \\
\hline Poço 10 & 0,27 & & & & & & & & \\
\hline
\end{tabular}

Ambas as técnicas de agrupamento mostraram resultados similares. No entanto, considera-se que os resultados dos agrupamentos hierárquicos foram mais consistentes, pois, como já citado, o número de grupos formados pelas técnicas divisivas é definido aleatoriamente. Além disso, as técnicas hierárquicas diminuem as perdas de informações, como já explanado na revisão bibliográfica desse trabalho.

\subsubsection{Definição dos Agrupamentos}

A definição dos cinco grupos foi determinada pelos valores de distância euclidiana obtidos. Analisando os dendogramas, e comparando-os com os resultados obtidos nas técnicas divisivas, nota-se a formação de 5 grupos, em que a distância euclidiana varia entre 0,5 e 0,6. A distância euclidiana dos próximos agrupamentos gerados encontram-se próximos a 1,0. No dendograma correspondente ao período de agosto de 2006 a agosto de 2008, essa discrepância entre as distâncias é mais perceptível. 
As figuras 16 a 20 apresentam para os grupos de poços formados as profundidades do nível d'água, ao longo dos quatro anos estudados.

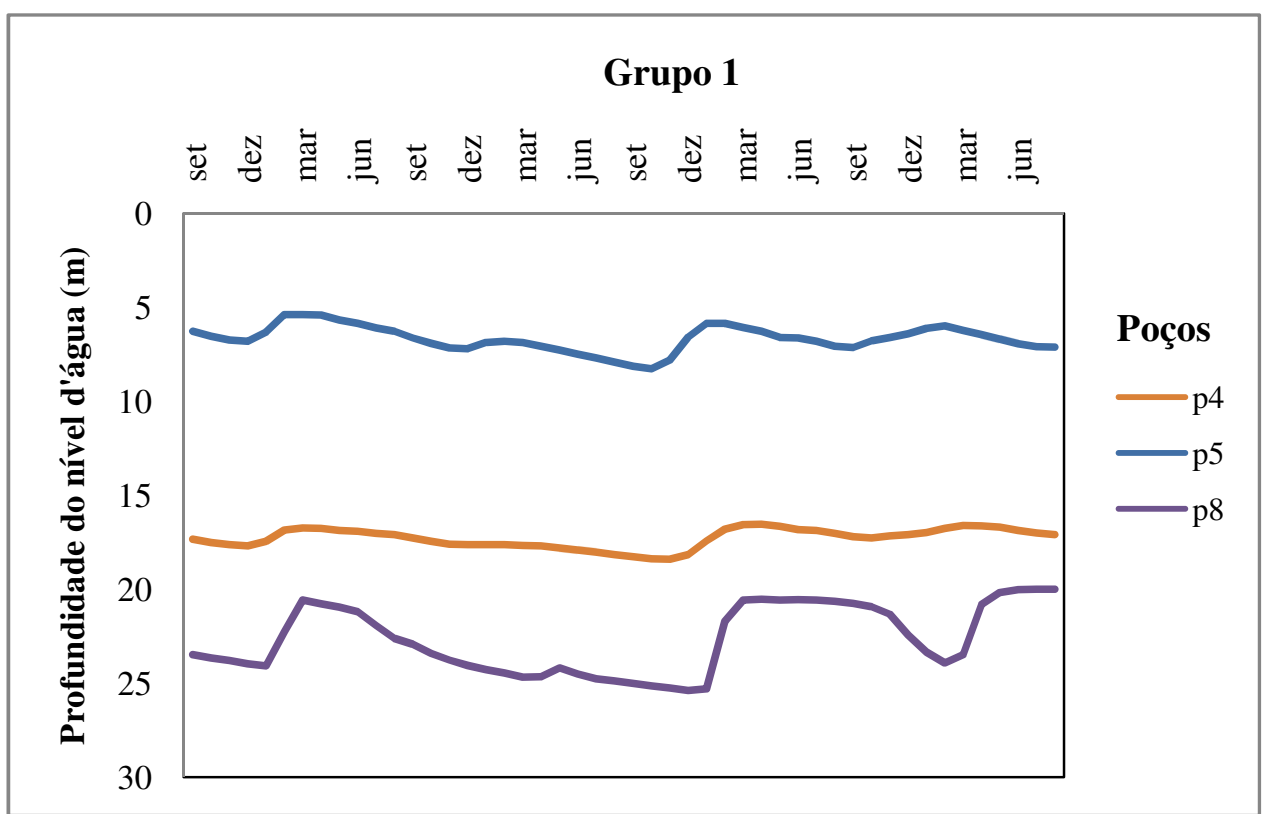

Figura 16: Variação do nível d'água nos poços do grupo 1.

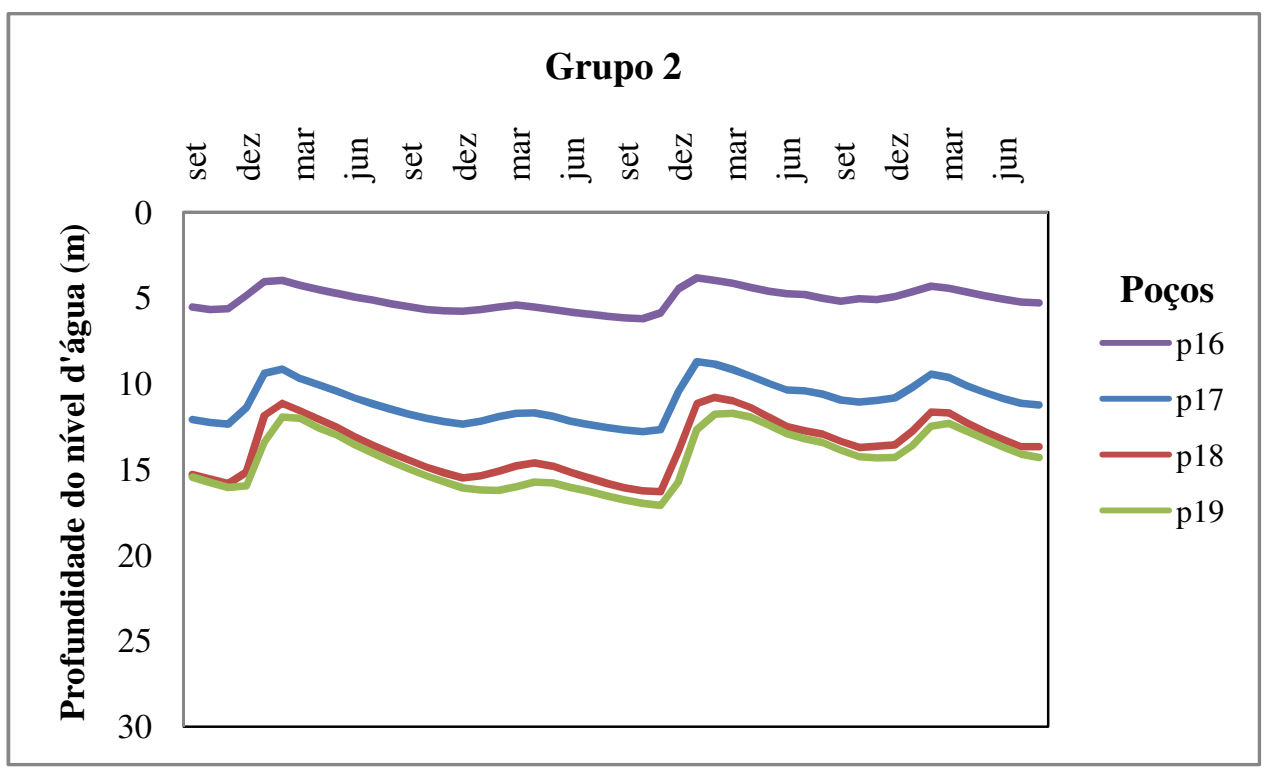

Figura 17: Variação do nível d'água nos poços do grupo 2. 
Grupo 3

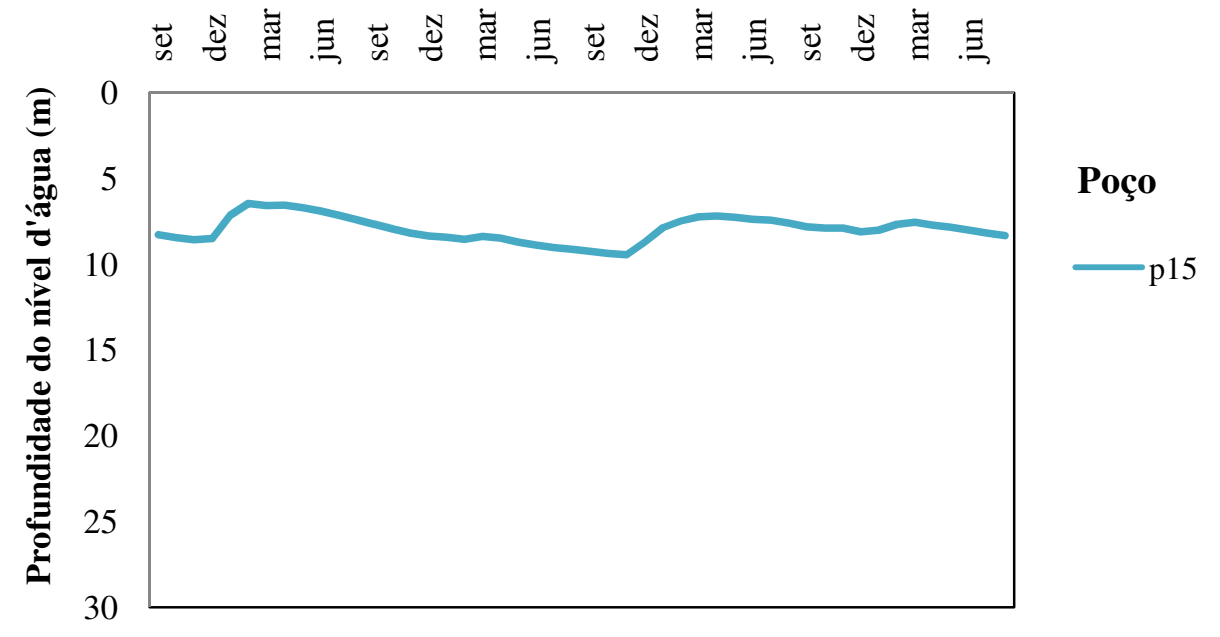

Figura 18: Variação do nível d'água no poço do grupo 3.

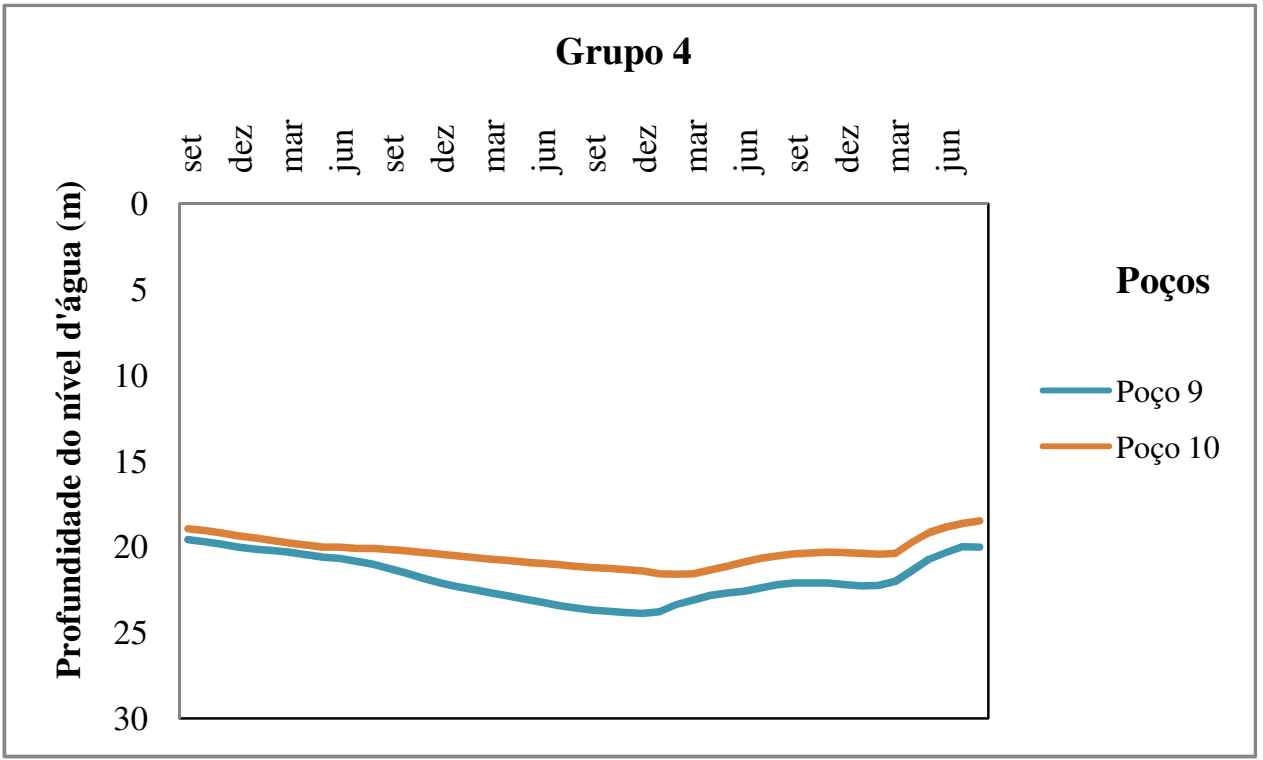

Figura 19: Variação do nível d'água nos poços do grupo 4. 


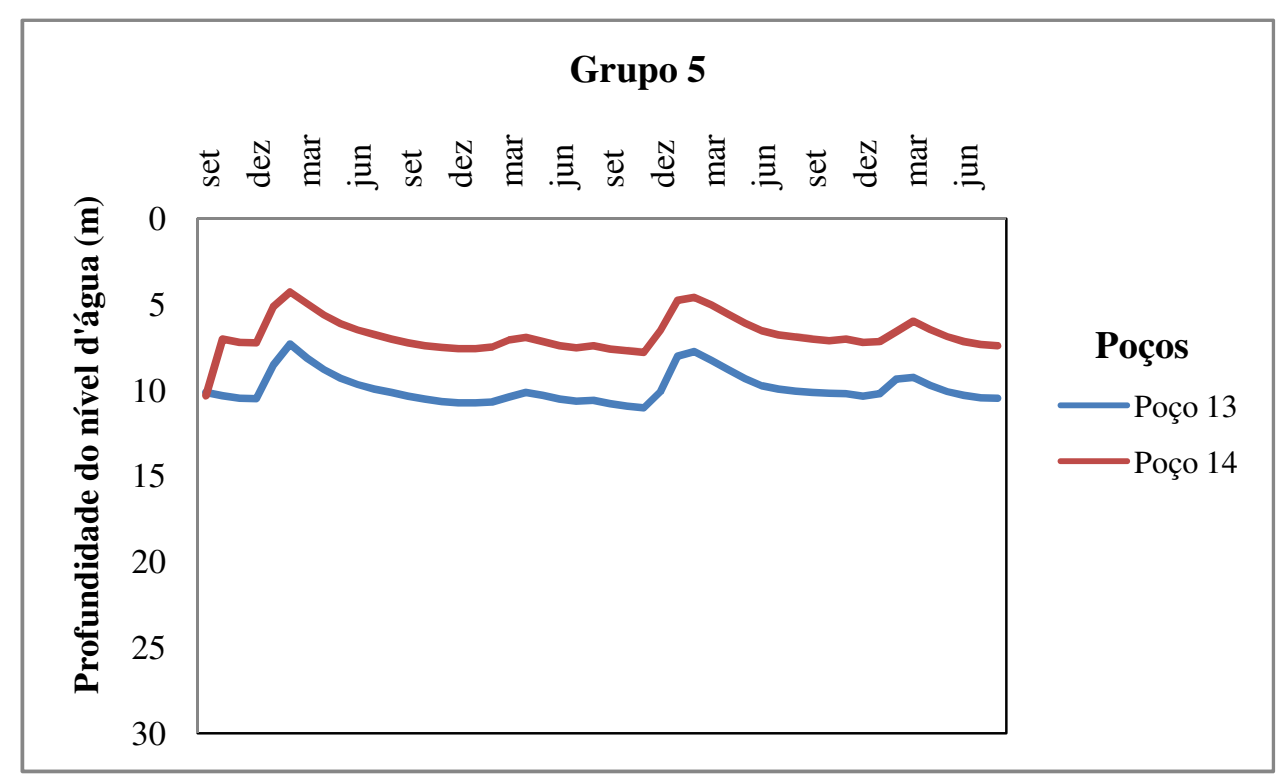

Figura 20: Variação do nível d'água nos poços do grupo 5.

O gráfico da figura 16 contém três poços. Esses estão localizados em áreas de culturas diferentes: poços 4 e 5 encontram-se em áreas de pastagem, o poço 8, após o ano de 2006, encontra-se localizado em área de cultivo de cana-de açúcar. No período anterior a agosto de 2006, na área em que o poço está localizado cultivava-se cítricos. O gráfico da figura 17 mostra a composição de um grupo de quatro poços $(16,17,18 \mathrm{e}$ 19), instalados em mesma área de cultura (pastagem). O gráfico da figura 18 contém apenas o poço 15 , que está localizado em área de cultivo de cítricos, mas que até o ano de 2006 encontrava-se localizado em área de cultivo de cana-de-açúcar. Os poços 13 e 14 encontram-se em áreas de cultivo de citricos e estão agrupados no gráfico da figura 19. A figura 20 mostra o gráfico contendo os níveis d'água nos poços 9 e 10, que estão localizados em regiões onde se cultiva eucalipto.

A análise dos grupos formados indica a variação do nível d'água como característica física de maior influência na formação de grupos de poços. No entanto o coeficiente de evapotranspiração, o qual está diretamente ligado a cultura da região, também se mostra como importante fator na definição dos agrupamentos. 
Os poços 4 e 5 estão localizados em áreas cujo coeficiente de evapotranspiração é de 0,9 , e o poço 8 localiza-se em área com coeficiente de evapotranspiração de 0,8 . No entanto, com a mudança de cultura na região do poço 8 , este passou a ter um coeficiente de evapotranspiração de 1,04 , e por isso, no dendograma referente ao periodo de mudança (agosto de 2006 a agosto de 2008), mostrado na figura 14, este poço está agrupado com os poços 9 e 10 (eucalipto) que possuem coeficiente de evapotranspiração da área igual a 1,0.

Os demais agrupamentos foram formados por poços localizados em região de mesma cultura. O poço 15 que se localiza em área onde houve mudança de cultura não teve, no entanto, seu agrupamento alterado. Este poço não se agrupou com nenhum outro, mesmo quando o coeficiente de evapotranspiração foi modificado.

Os agrupamentos mostram ainda que a porosidade exerce importante papel no processo de variação do nível d'água nos poços monitorados. Os agrupamentos mostrados nos gráficos das figuras 17,19 e 20 contém poços localizados em regiões de alta porosidade $(15,9 \%$ e $15,1 \%)$. O grupo mostrado no gráfico da figura 16 , contém poços de áreas cuja porosidade é igual a $12,3 \%$. E o poço 15 é o único localizado em área com porosidade igual a 8,5\%, o que denota a importância de tal característica física na região. Com a mudança de coeficiente de evapotranspiração era esperado que o poço 15 mudasse o agrupamento. $\mathrm{O}$ fato de não ter ocorrido ratifica a importância da porosidade como atributo de agrupamento.

Quanto à variação do nível d'água, afirma-se que este também é fator fundamental na divisão dos poços em grupos, pois estes valores foram utilizados no cálculo da distância euclidiana, uma vez que os demais atributos são fixos. Além disso, os poços 9 e 10 possuem, como pode-se perceber na figura 19, variação da profundidade do nível d'água diferenciada dos demais poços. 
Os resultados obtidos mostram a importância das variáveis utlizadas para o agrupamento, confirmando a necessidade de estudos mais aprofundados quanto aos demais fenômenos hidrológicos, para o melhor entendimento do funcionamento da recarga na bacia do Ribeirão da Onça. Não é possível definir qual atributo é mais importante para a formação de grupos. Contudo, a variação do nível d'água nos poços foi definida como caracteristica deteminante por dois motivos: é a única caracteristica que sofre variações nos valores ao longo dos anos estudados, e está diretamente ligada às demais caracteristicas utilizadas, uma vez que a porosidade e o coeficiente de evapotranspiração influenciam o processo de infiltração da água no solo.

\subsection{ANÁLISE DAS SÉRIES DE PRECIPITAÇÃO E NÍVEL D’ÁGUA}

Os dados obtidos foram submetidos à análise de séries temporais, onde se buscou avaliar a sazonalidade, bem como autocorrelação dos mesmos. Foi utilizado o software Systat, para a geração dos gráficos. Para o estudo de autocorrelação dos poços, foram utilizadas as variações mensais das séries de dados. Dessa maneira, a defasagem aplicada igual a 48 , equivale aos quatro anos de estudo.

As figuras 21 a 32 apresentam os correlogramas das séries de dados referentes a variação mensal dos níveis d'água nos poços 4 a 19. 


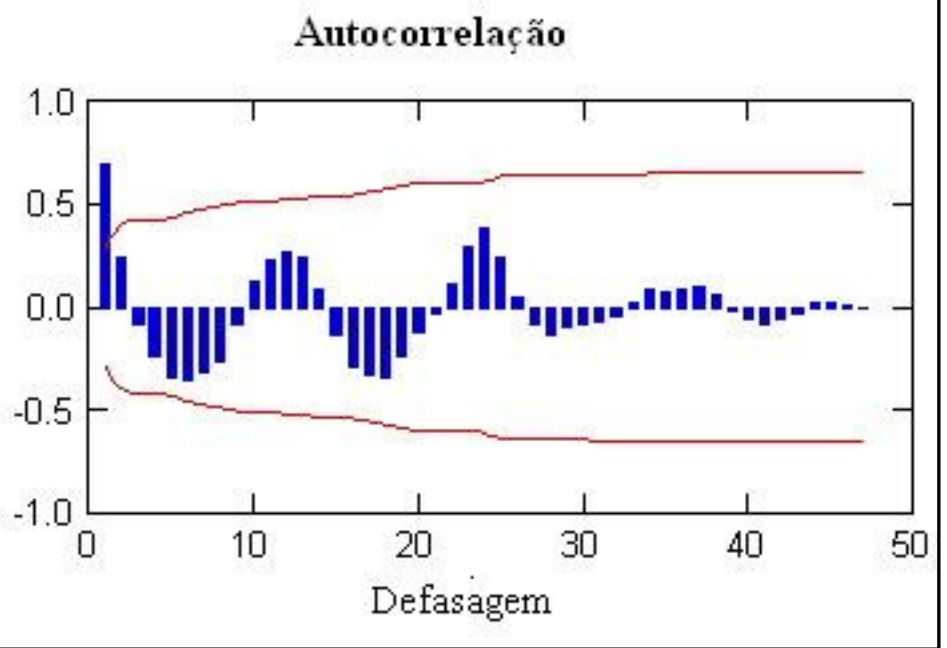

Figura 21: Correlograma do poço 4, para o período de outubro de 2004 a setembro de 2008.

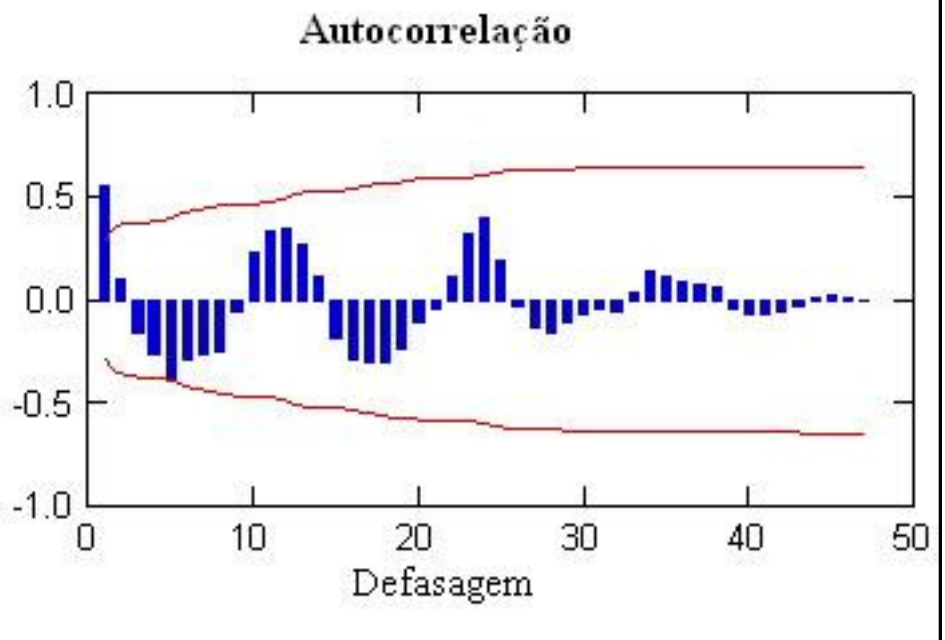

Figura 22: Correlograma do poço 5, para o período de outubro de 2004 a setembro de 2008. 


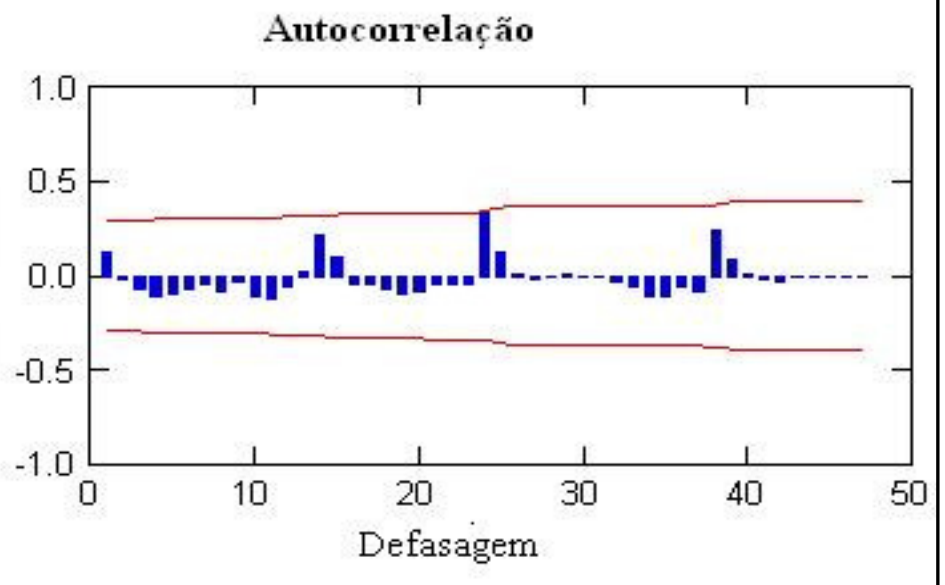

Figura 23: Correlograma do poço 8, para o período de outubro de 2004 a setembro de 2008.

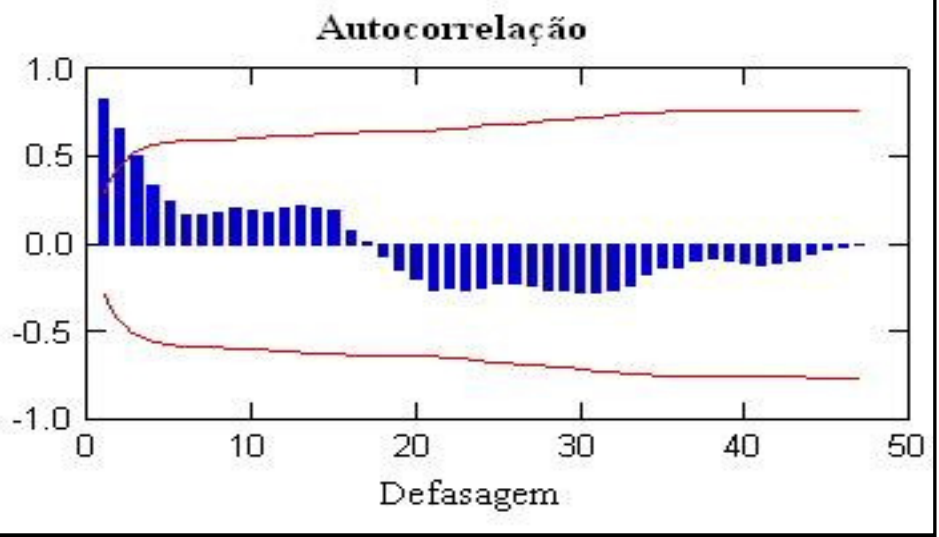

Figura 24: Correlograma do poço 9, para o período de outubro de 2004 a setembro de 2008.

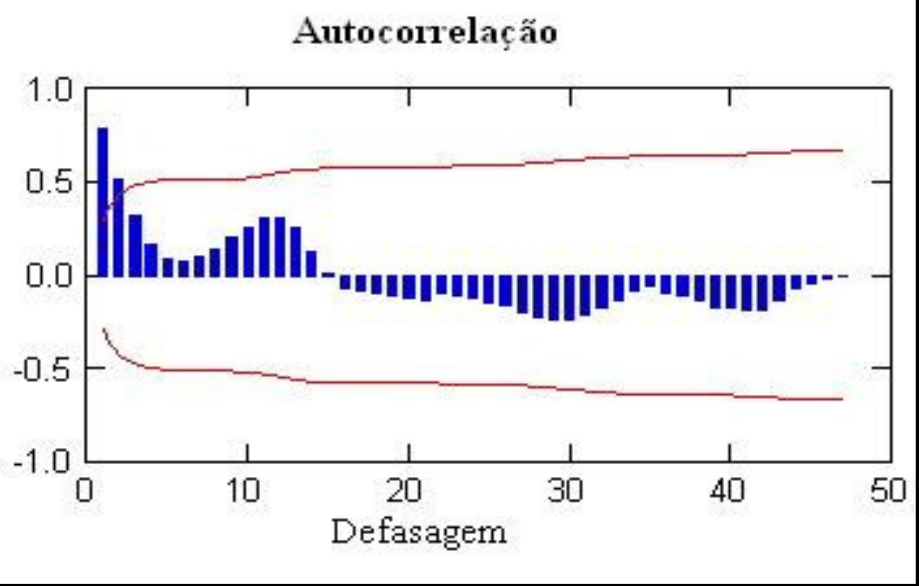

Figura 25: Correlograma do poço 10, para o período de outubro de 2004 a setembro de 2008. 


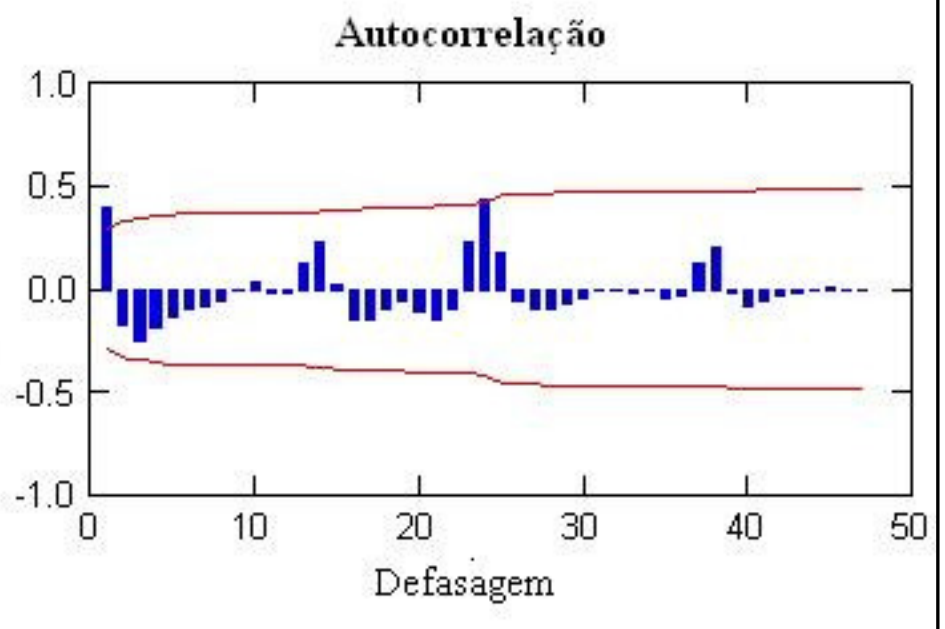

Figura 26: Correlograma do poço 13, para o período de outubro de 2004 a setembro de 2008.

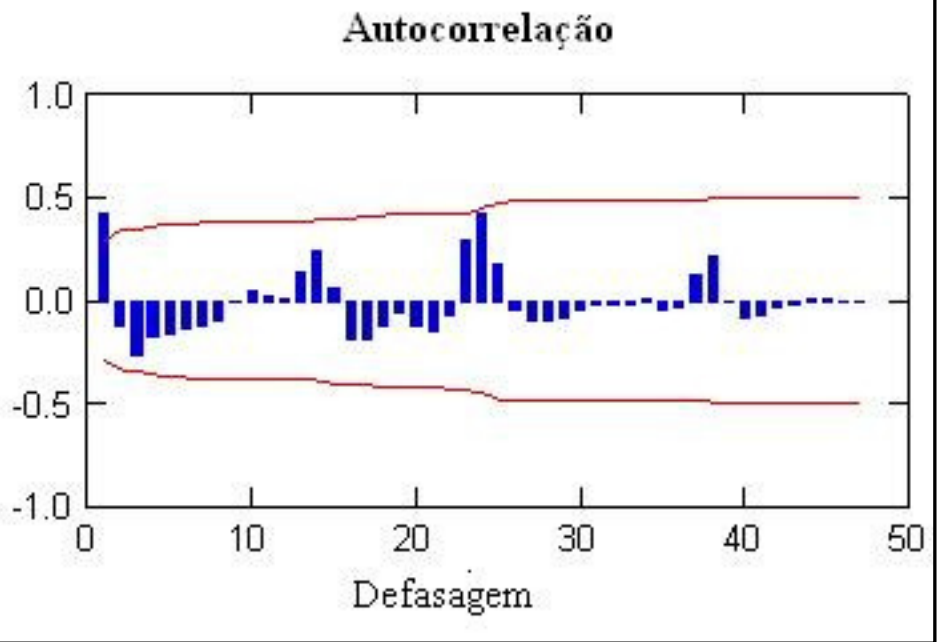

Figura 27: Correlograma do poço 14, para o período de outubro de 2004 a setembro de 2008. 


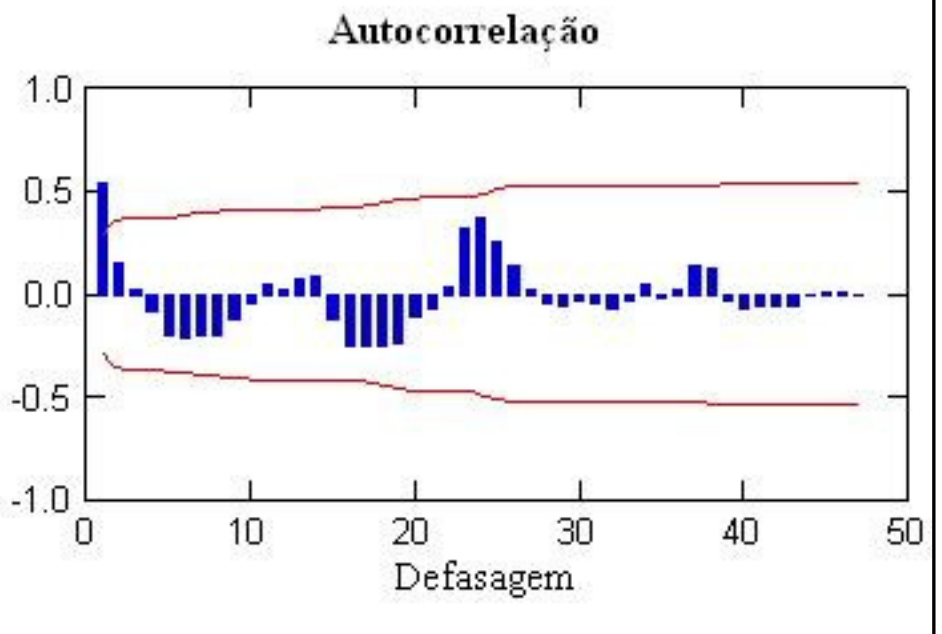

Figura 28: Correlograma do poço 15, para o período de outubro de 2004 a setembro de 2008.

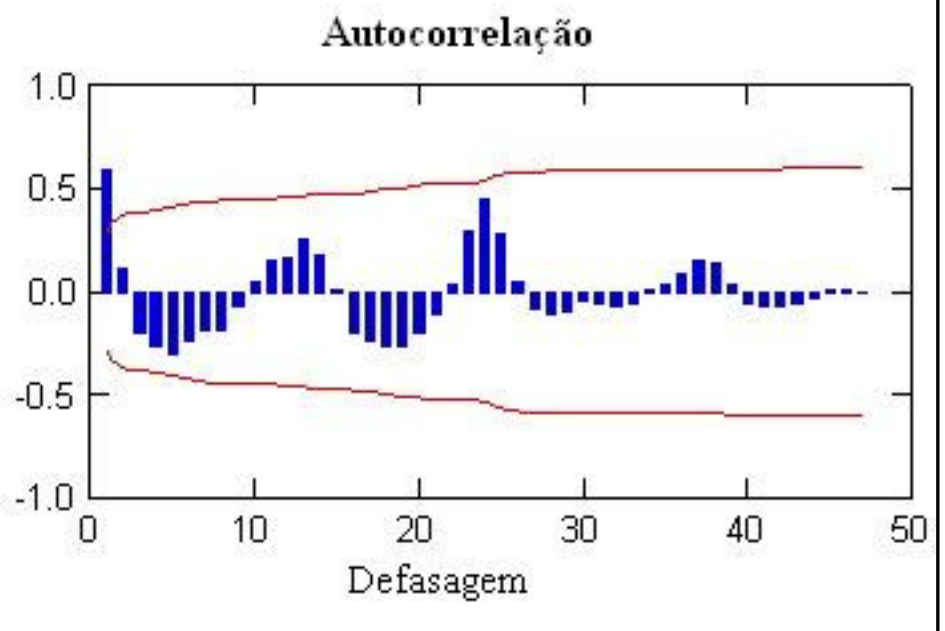

Figura 29: Correlograma do poço 16, para o período de outubro de 2004 a setembro de 2008. 


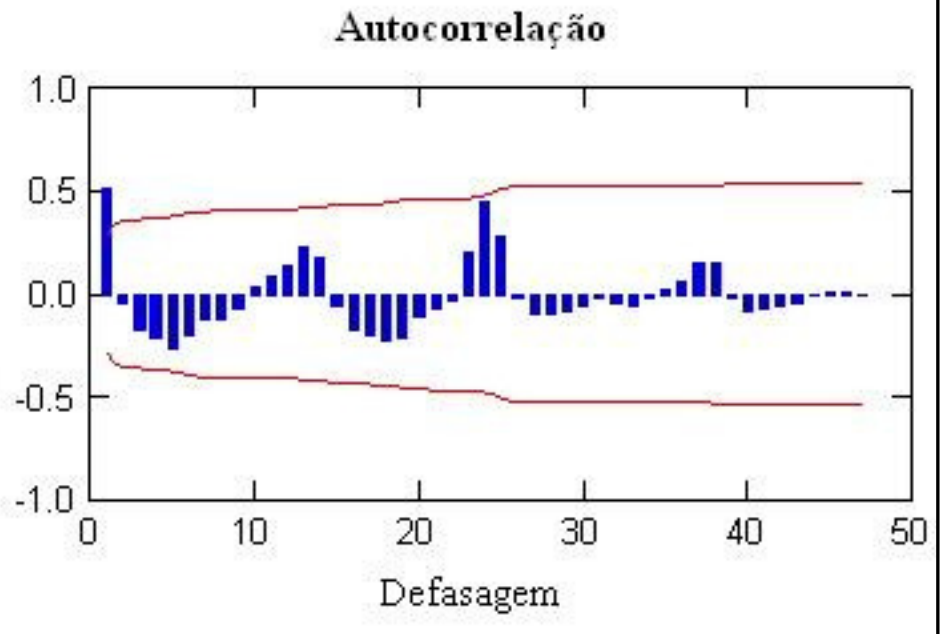

Figura 30: Correlograma do poço 17, para o período de outubro de 2004 a setembro de 2008.

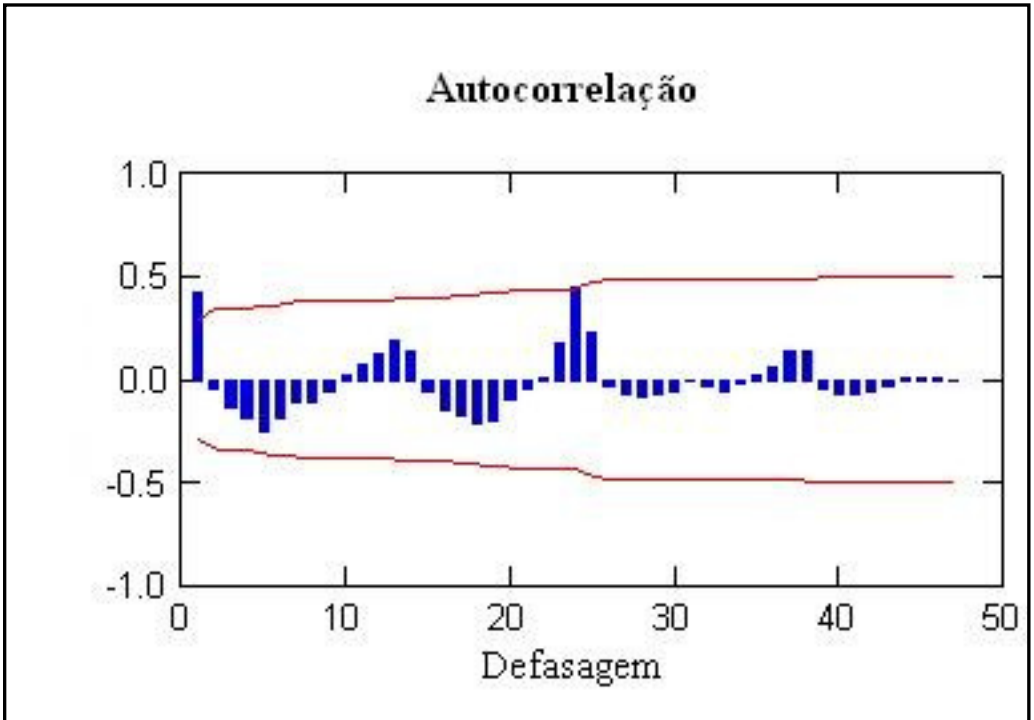

Figura 31: Correlograma do poço 18, para o período de outubro de 2004 a setembro de 2008. 


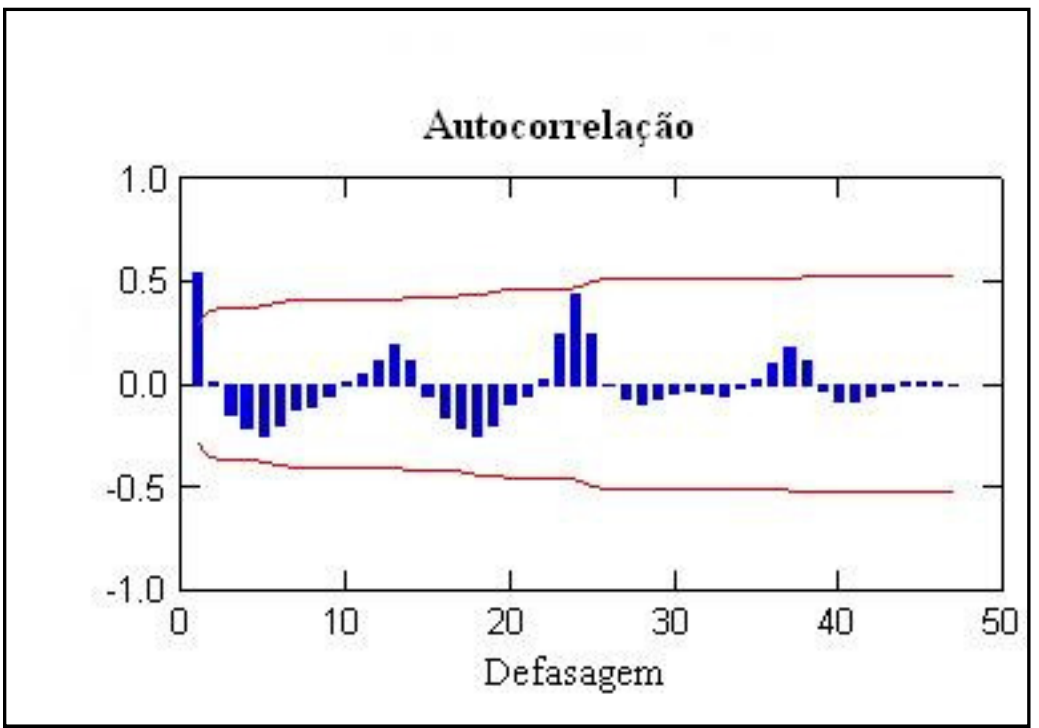

Figura 32: Correlograma do poço 19, para o período de outubro de 2004 a setembro de 2008.

A análise das séries temporais permite notar que há uma forte sazonalidade da variação do nível d’água nos poços estudados. Esses períodos, como já dito anteriormente, coincidem com a sazonalidade das chuvas da região.

A heterogeneidade quanto à profundidade dos poços, uma vez que há poços que atingem até $25 \mathrm{~m}$ de profundidade (poço 8) enquanto há poços de, aproximadamente, 6m de profundidade (poço 16), reflete na variação dos níveis d'água. Isto quer dizer que poços mais rasos devem responder mais rapidamente aos eventos de precipitação e infiltração, enquanto que os mais profundos têm respostas mais lentas.

No que diz respeito à autocorrelação, pode-se afirmar que em todos os poços monitorados há uma boa correlação entre os dados observados. Tal resultado já era esperado, pois se trata de valores acumulados, ou seja, a profundidade verificada em um determinado dia encontra-se relacionada à do dia anterior.

Baseado na revisão de literatura é possível concluir que se trata de séries de correlações de curto prazo, uma vez que ocorre o declínio dos valores de autocorrelação com o aumento da defasagem. Além disso, essa característica ratifica a existência de sazonalidade. 
As linhas vermelhas encontradas nos correlogramas indicam a previsão das séries, ou seja, caso não houvesse variações cíclicas (sazonalidades), a autocorrelação das séries de dados seguiriam a tendência das linhas, podendo ser negativas ou positivas. Os valores de autocorrelação iniciais encontram-se acima da linha de previsão, o que mostra a existência de correlação de curto prazo. Isso quer dizer que, com o aumento da defasagem há uma diminuição da correlação, o que, novamente, enfatiza a existência de um comportamento sazonal na variação dos níveis d'água dos poços estudados.

Os poços 9 e 10, apresentados nas figuras 24 e 25, estão localizados em região de cultivo de eucalipto e possuem autocorrelações diferenciadas. Nota-se a existência de dois períodos distintos: para os dois primeiros anos de estudo as autocorrelações são positivas, correspondendo ao período em que não há elevação do nível d'água nos poços, a partir da defasagem aproximadamente equivalente a 20 (o que corresponde ao final do ano de 2005), nota-se que as autocorrelações tornam-se negativas, mostrando que se tem o inicio da elevação do nível d'água nos poços. Tal resultado mostra a importância de estudos mais aprofundados sobre a influência do cultivo de eucalipto em regiões de recarga de águas subterrâneas.

A autocorrelação da série de dados referentes a precipitação, reflete a alta variabilidade das chuvas na região estudada. Apesar de ser conhecida a existência de sazonalidade, sabe-se que, ao longo dos anos estudados, há muitos dias, mesmo em períodos chuvosos, em que não foram verificados eventos de precipitação. Conseqüentemente, a autocorrelação dessa série de dados é muito baixa, o que demonstra que os eventos de precipitação não são influenciados pelos ocorridos em dias anteriores, sendo, portanto, eventos independentes. 


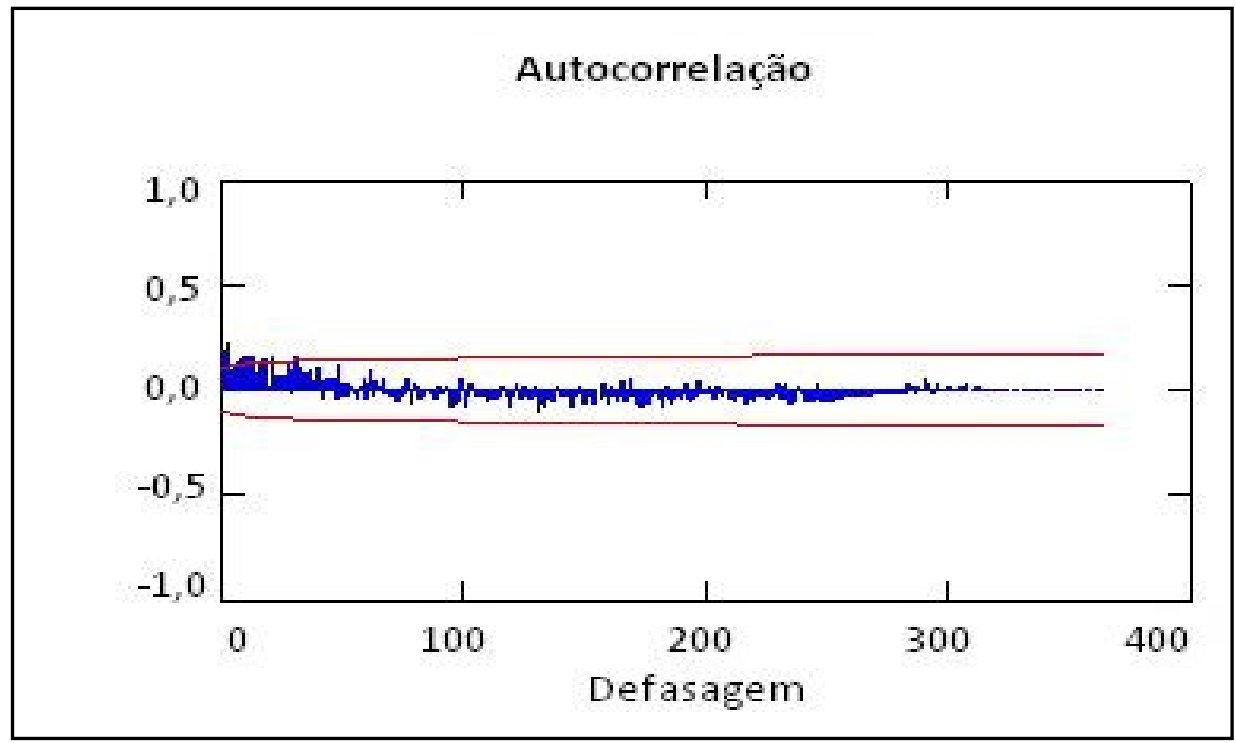

Figura 33: Correlograma da série de precipitação diária, para o período de setembro de 2006 a agosto de 2007.

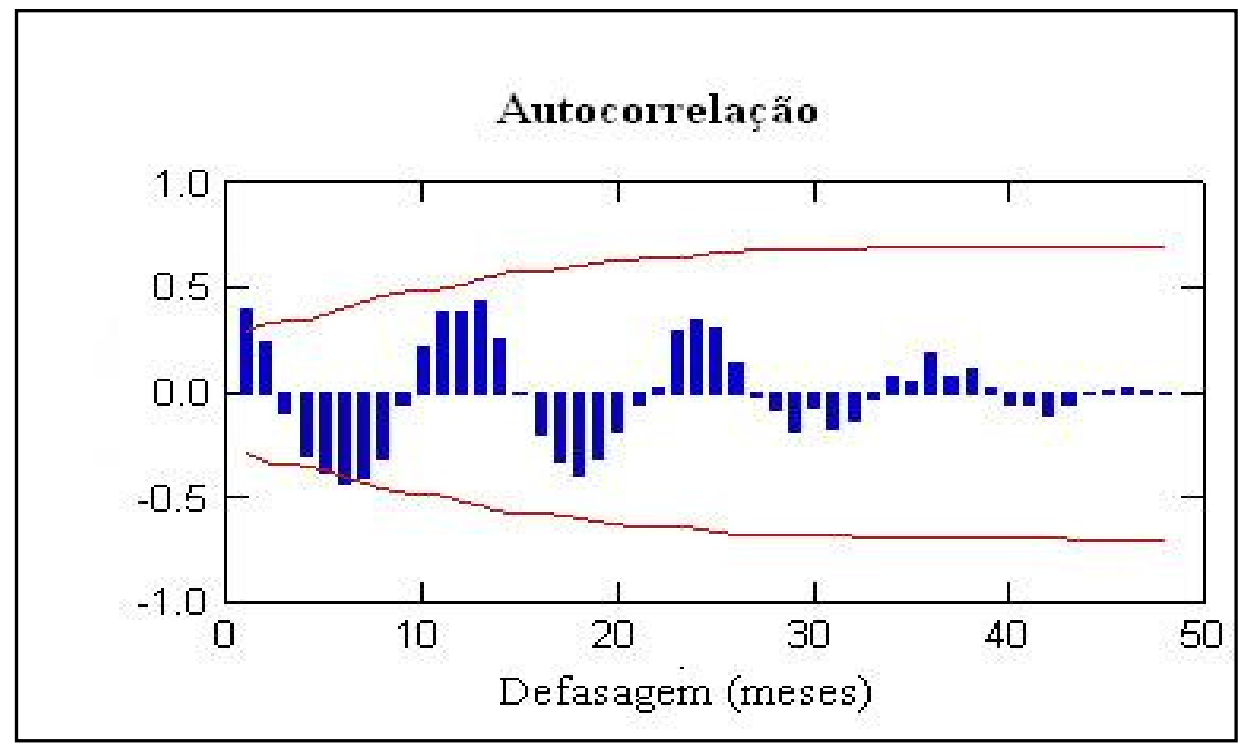

Figura 34: Correlograma da série de precipitação acumulada mensal, para os anos analisados.

Observado o correlograma da figura 33 e diante dos valores diários de precipitação, encontrados no apêndice B, optou-se por calcular a autocorrelação para os totais mensais (precipitação acumulada mensalmente). A figura 34 mostra essa autocorrelação. Neste correlograma é possível definir a sazonalidade das chuvas na região, fato que ratifica os resultados obtidos com a estatística descritiva. A defasagem 
mensal mostra que, ao longo de um ano há bem definidamente períodos chuvosos e de estiagem.

\subsection{ANÁLISES DE CORRELAÇÃO}

O principal objetivo do presente estudo foi o de avaliar a correlação entre dois fenômenos hidrológicos: precipitação e variação do nível d'água no aquífero. Para isso, foi proposto o uso do cálculo de coeficiente estatístico de correlação, denominado coeficiente de correlação de Pearson. É importante salientar que esse coeficiente não define uma relação de dependência entre as variáveis estudadas, e sim mostra a existência, ou não, de uma influência entre as mesmas. No presente estudo, contudo, sabe-se que a precipitação é o fenômeno responsável pela recarga de um aquífero, o que torna possivel afirmar a existência de dependência entre as variáveis. Assim, o coeficiente de correlação foi usado para identificar o quão forte é esta relação, bem como se esta reação é imediata, ou seja, se um evento de precipitação gera, imediatamente, uma elevação no nível do aquifero.

\subsubsection{Correlação entre os Poços Monitorados}

Previamente, calculou-se a correlação entre os poços monitorados, utilizando as variações diárias do nível d'água. O objetivo foi verificar a existência de relações entre poços localizados na mesma cultura. A tabela 7 mostra os valores obtidos. 
Tabela 7: Coeficiente de correlação (Pearson) entre variaçõe diárias do nível d'água nos poços monitorados.

\begin{tabular}{|c|c|c|c|c|c|c|c|c|c|c|c|}
\hline & P5 & P8 & P9 & P10 & P13 & P14 & P15 & P16 & P17 & P18 & P19 \\
\hline$\overline{P 4}$ & $\overline{0,87}$ & 0,20 & 0,19 & $-0,17$ & 0,58 & 0,53 & 0,01 & 0,59 & $\overline{0,61}$ & 0,49 & $\overline{0,79}$ \\
\hline P5 & & 0,04 & 0,05 & $-0,24$ & 0,64 & 0,64 & 0,01 & 0,69 & 0,64 & 0,49 & 0,73 \\
\hline P8 & & & 0,37 & 0,21 & $-0,14$ & $-0,12$ & $-0,01$ & $-0,09$ & $-0,08$ & 0,01 & 0,16 \\
\hline P9 & & & & 0,80 & $-0,08$ & $-0,08$ & $-0,13$ & $-0,05$ & $-0,07$ & $-0,02$ & 0,08 \\
\hline P10 & & & & & $-0,30$ & $-0,27$ & $-0,03$ & $-0,23$ & $-0,32$ & $-0,24$ & $-0,28$ \\
\hline P13 & & & & & & $\mathbf{0 , 9 3}$ & 0,02 & 0,71 & 0,82 & 0,56 & 0,63 \\
\hline P14 & & & & & & & 0,01 & 0,81 & 0,70 & 0,42 & 0,47 \\
\hline P15 & & & & & & & & 0,00 & 0,03 & 0,03 & 0,03 \\
\hline P16 & & & & & & & & & 0,68 & 0,38 & 0,46 \\
\hline P17 & & & & & & & & & & $\mathbf{0 , 8 9}$ & 0,76 \\
\hline P18 & & & & & & & & & & & 0,69 \\
\hline
\end{tabular}

Os valores obtidos mostram que há uma boa correlação entre as culturas existentes na área em que os poços estão localizados. Os valores relativos a variação do nível d'água no poço 4 geraram bons coeficientes de correlação quando relacionados aos valores de variações dos níveis d'água dos poços 5, 16, 17, 18 e 19, os quais, assim como o poço 4, estão localizados em área de pastagem. Essa relação se repete para o o poço 5, também localizado em área de pastagem, o qual gerou coeficientes de correlação de altos valores quando relacionados aos poços supracitados. Apenas quando correlacionados com os valores de nível d'água do poço 18, os valores dos poços 4 e 5 geram coeficientes um pouco menores $(r=0,49)$, o que pode ser explicado pelas diferentes profundidades dos poços.

Os coeficientes de correlação do poço 8 não resultaram em valores significativos com os demais poços, nem mesmo com os poços 13 e 14, localizados em área de cultivo de citricos (assim como o poço 8). Os valores de nível d'água dos poços 13 e 14, quando correlacionados, resultaram em elevado coeficiente $(r=0,93)$. É importante ressaltar que o poço $8(22,9 \mathrm{~m})$ possui uma profundidade média maior que 
os poços 13 e 14 (9,8 m e 6,6 m, respectivamente), o que pode explicar os diferentes valores de correlação.

No segundo semestre do ano de 2006 a cultura da área em que está localizado o poço 8 foi modificada. Em tal área passou-se a cultivar cana-de-açúcar. Essa mudança pode provocar alterações no processo de infiltração da água, fazendo com que, consequentemente, a variação do nível d'água do poço 8 também seja alterada, o que explica os coeficientes de correlação deste poço serem menores se comparados com os poços onde há o cultivo de citricos.

A análise de correlação entre a variação do nível d'água no poço 15 e essa variação nos demais poços não resultou em altos coeficientes de correlação, o que pode ser explicado pelo fato de ser o único poço localizado em região de cultivo de cana-deaçúcar. Na região em que o poço está localizado também ocorreu mudança de cultura. Em 2006, passou-se a cultivar cítricos.

Os valores de nível d'água dos poços 9 e 10, localizados em culturas de eucalipto, geraram coeficiente de correlação elevado entre si. Em relação aos demais poços, o coeficiente de correlação das variações de nível d'água gerados são baixos, indicando que não há correlação entre os poços localizados em região de cultura de eucalipto e os poços localizados em regiões de outras culturas.

A análise dos valores dos níveis d'água nos poços 13, 14, 16 e 17 gerou altos coeficientes de correlação. Considerando que os poços 13 e 14 estão localizados em área de citricos, enquanto que os poços 16 e 17 estão localizados em região de pastagem, conclui-se que a profundidade de nível d'água nesses poços é fator influenciador da boa correlação, uma vez que a profundidade dos quatro poços varia entre 5,1 m (poço 16) e 11,1 m (poço 17). 
De maneira geral, os melhores coeficientes de correlação foram obtidos entre poços localizados em áreas de mesma cultura. Além disso, a profundidade do poço também influencia na correlação, conforme citado, no caso dos poços 13, 14,16 e 17.

As correlações entre as variações diárias do nível d'água nos poços monitorados mostram que os mais altos coeficientes são obtidos da relação entre poços localizados em mesma cultura. Quando comparados aos grupos formados a partir das técnicas de agrupamento, nota-se que os resultados são consistentes, já que os poços alocados em um mesmo grupo estão localizados em área de mesma cultura. Esse resultado é de grande importância pois permite determinar que o coeficiente de evapotranspiração, que está diretamente ligado a cultura da região, tem grande influência na variação do nível d'água nos poços monitorados.

\subsubsection{Correlação entre Variação Mensal do Nível d'Água e Precipitação Mensal}

Após o cálculo da correlação entre as variações diárias de nível d'água nos poços, foi calculado, para cada poço, o coeficiente de correlação de Pearson, em relação a precipitação. Inicialmente, foram utilizados valores diários de variação do nível d'água e de precipitação. Os coeficientes obtidos foram muito baixos e, portanto, descartados do estudo. Contudo, esses valores mostraram um importante resultado inicial: o método das correlações não é sensível a pequenas variações (as variações diárias nos poços são de, aproximadamente, 0,01m). Aliado a isso, deve-se considerar o fato de a precipitação na região ser irregular, ocorrendo períodos (dias) consideráveis sem ocorrência de chuva.

Os cálculos de coeficientes de correlação utilizando valores mensais de precipitação acumulada e variação mensal do nivel d'água, em cada poço, mostraram coeficientes mais elevados se comparados aos coeficientes gerados por variações diárias. No entanto, em todos os poços os coeficientes de correlação, para variações 
mensais, também foram baixos. Não é possível afirmar que os fenômenos não estão relacionados, uma vez que se sabe que a precipitação é fator primário no processo de recarga de aquíferos. Os baixos valores de correlação mostram duas possibilidades importantes: a correlação entre os fenômenos estudados não ocorre de maneira linear e/ou; não é possivel estudar a existência de uma relação entre precipitação e recarga do aquífero sem considerar outros importantes fenômenos hidrológicos, principalmente, infiltração e evapotranspiração, os quais estão diretamente ligados aos processos de recarga.

Desta forma desenvolveu-se o cálculo de correlação, utilizando os dados em escala logarítmica, uma vez que, de acordo com SPIEGEL (1970), a utilização de escalas logarítmicas mostra-se como importante ferramenta na detecção da existência de correlação não-linear. Abaixo, encontra-se a tabela comparativa, com valores do coeficiente de correlação das variações mensais de nível d'água e precipitação acumulada, em escala logarítmica e normal.

Tabela 8: Coeficiente de correlação (Pearson) para as variáveis precipitação e variação mensal do nível d'água em escala logarítmica e em escala normal, para o período de setembro de 2004 a setembro de 2008.

\begin{tabular}{c|c|c}
\hline Poços & $\begin{array}{c}\text { Coeficiente de Correlação } \\
(\mathbf{r}) \text { - Escala Logaritimica }\end{array}$ & $\begin{array}{c}\text { Coeficiente de Correlação } \\
(\mathbf{r}) \text { - Escala Normal }\end{array}$ \\
\hline 4 & 0,28 & $-0,38$ \\
5 & 0,24 & $-0,46$ \\
8 & 0,02 & $-0,11$ \\
9 & $-0,54$ & $-0,18$ \\
10 & $-0,14$ & $-0,05$ \\
13 & $-0,24$ & $-0,41$ \\
14 & $-0,20$ & $-0,44$ \\
15 & 0,30 & $-0,36$ \\
16 & 0,56 & $-0,24$ \\
17 & 0,35 & $-0,20$ \\
18 & 0,20 & $-0,14$ \\
19 & $-0,21$ & $-0,06$ \\
\hline
\end{tabular}

Nota-se um amumento dos coeficientes de correlação obtidos entre as variáveis precipitação e variação do nível d'água em escala logarítmica, para todos os poços, com 
exceção do poços 9, 10 e 19. Esse resultado mostra que não há ocorrência de uma correlação linear entre as variáveis estudadas, indicando que os níveis d'água nos poços não respondem de maneira imediata aos eventos de precipitação.

\subsubsection{Análise de Correlação em Períodos de Elevação do Nível d’Água}

A partir da análise dos gráficos de monitoramento dos poços, que mostram valores diários de precipitação e profundidade do nível d'água (apêndice B), nota-se que há um período de defasagem entre esses eventos. Considerando tal observação, optou-se por relacionar a variação do nível d'água (calculada a partir de curvas de recessão, conforme explicado na metodologia, seção 3.4.3.2.) e a precipitação acumulada para o mesmo período da variação do nível. As figuras 35 a 46 apresentam os gráficos de dispersão dos valores das variáveis estudadas e os coeficientes de correlação obtidos, para correlações lineares e exponenciais.

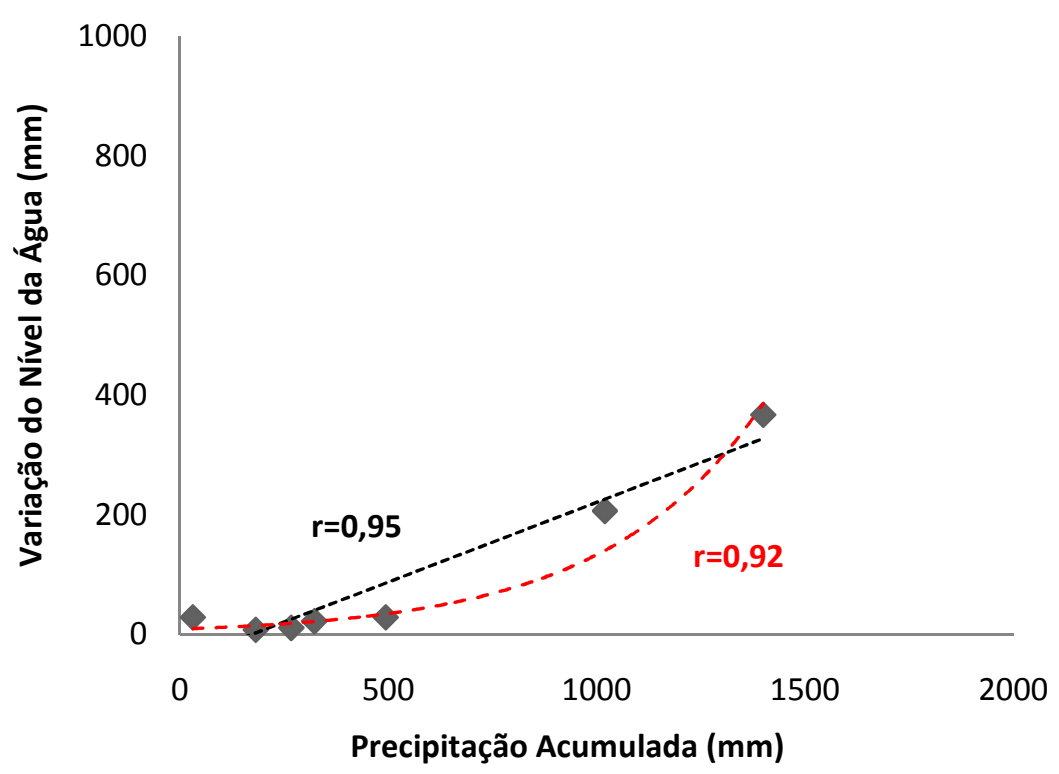

Figura 35: Correlação entre variação do nível d'água e precipitação acumulada no poço 4, localizado em aréa de pastagem, para o período de setembro de 2004 a setembro de 2008 . 


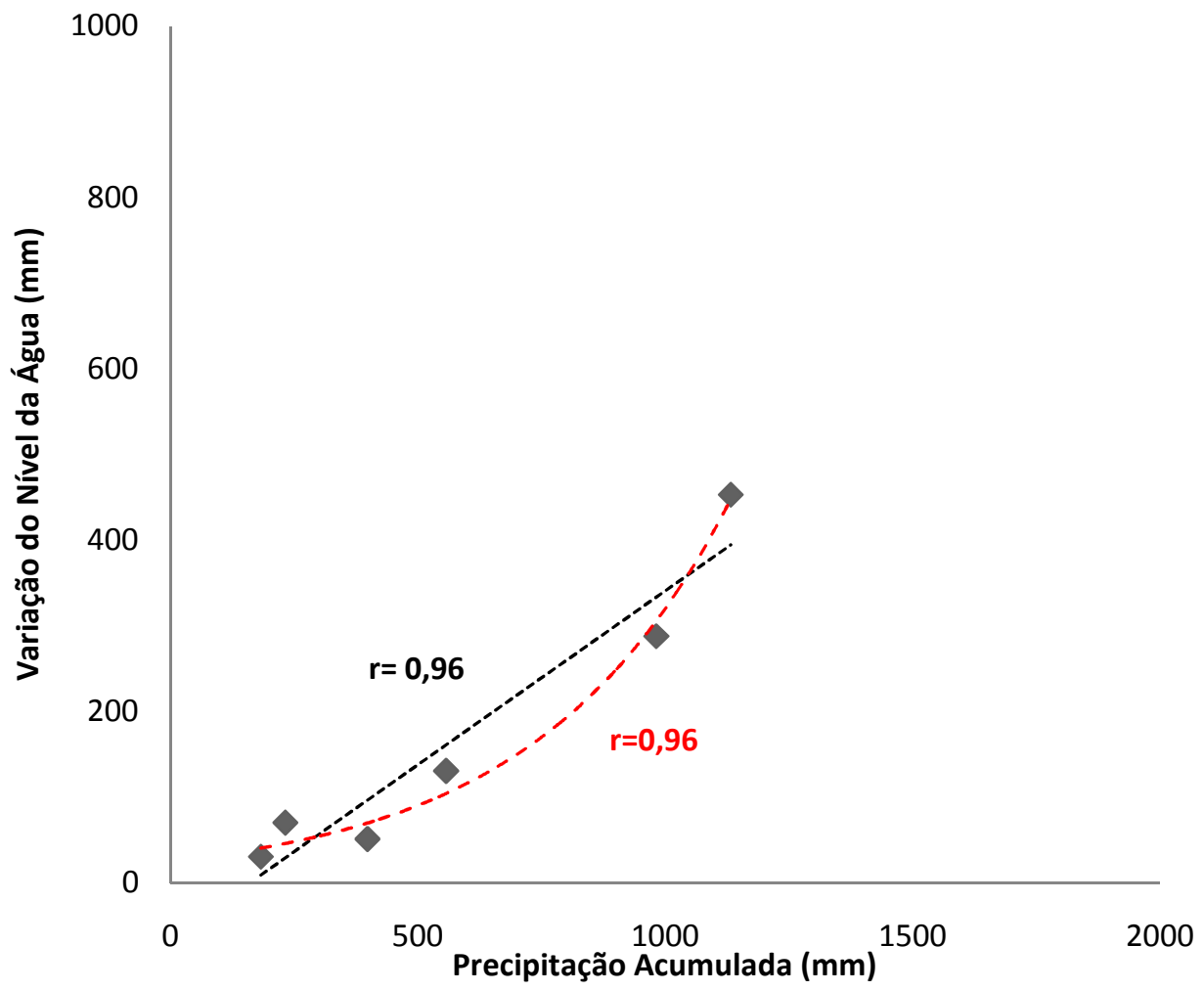

Figura 36: Correlação entre variação do nível d'água e precipitação acumulada no poço 5, localizado em área de pastagem, para o período de setembro de 2004 a setembro de 2008.



Figura 37: Correlação entre variação do nível d'água e precipitação acumulada no poço 8 , localizado em região de cultivo de cítricos, para o período de setembro de 2004 a setembro de 2008 . 


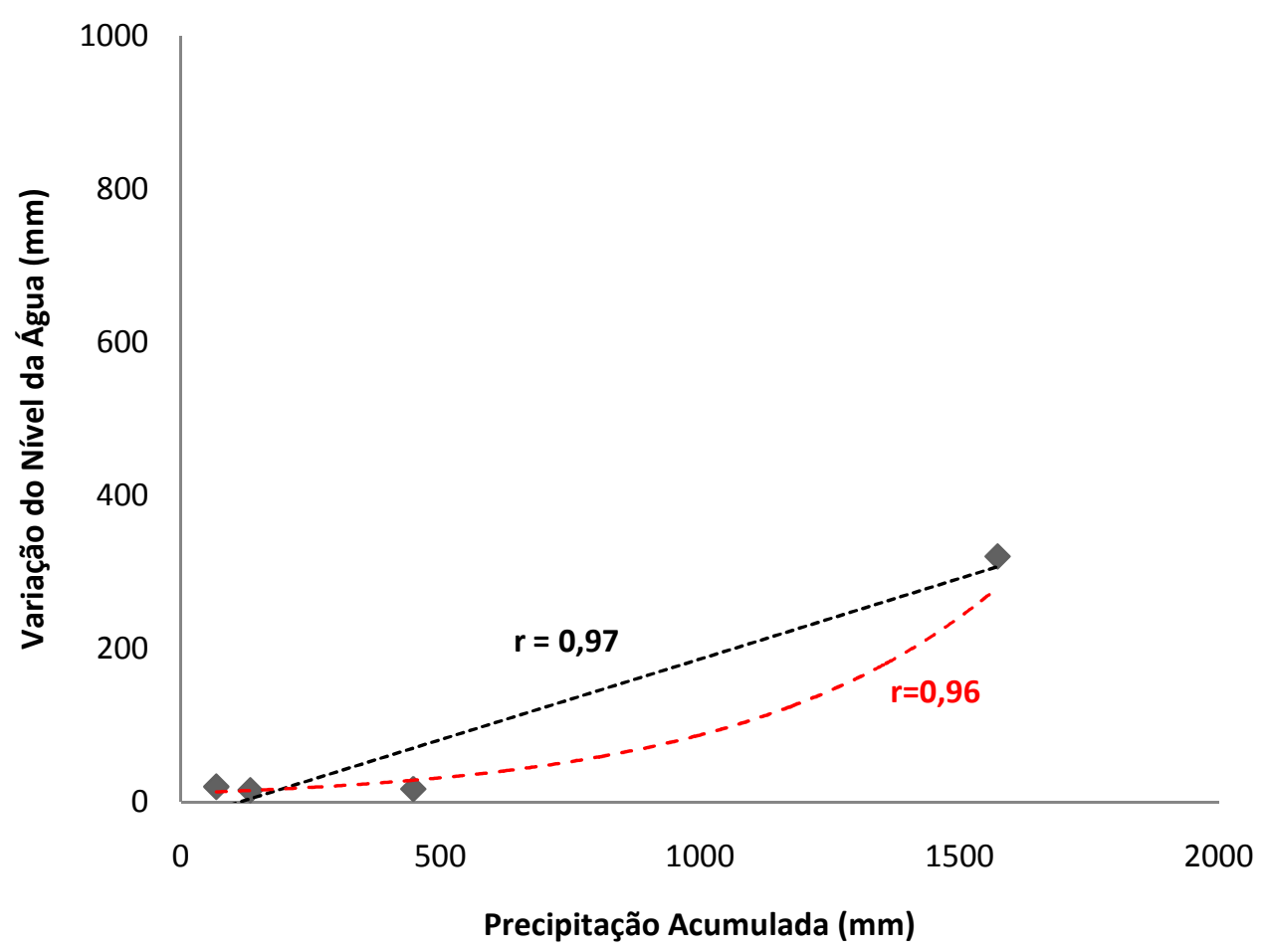

Figura 38: Correlação entre variação do nível d'água e precipitação acumulada no poço 9, localizado em região de cultivo de eucaliptos, para o período de setembro de 2004 a setembro de 2008.

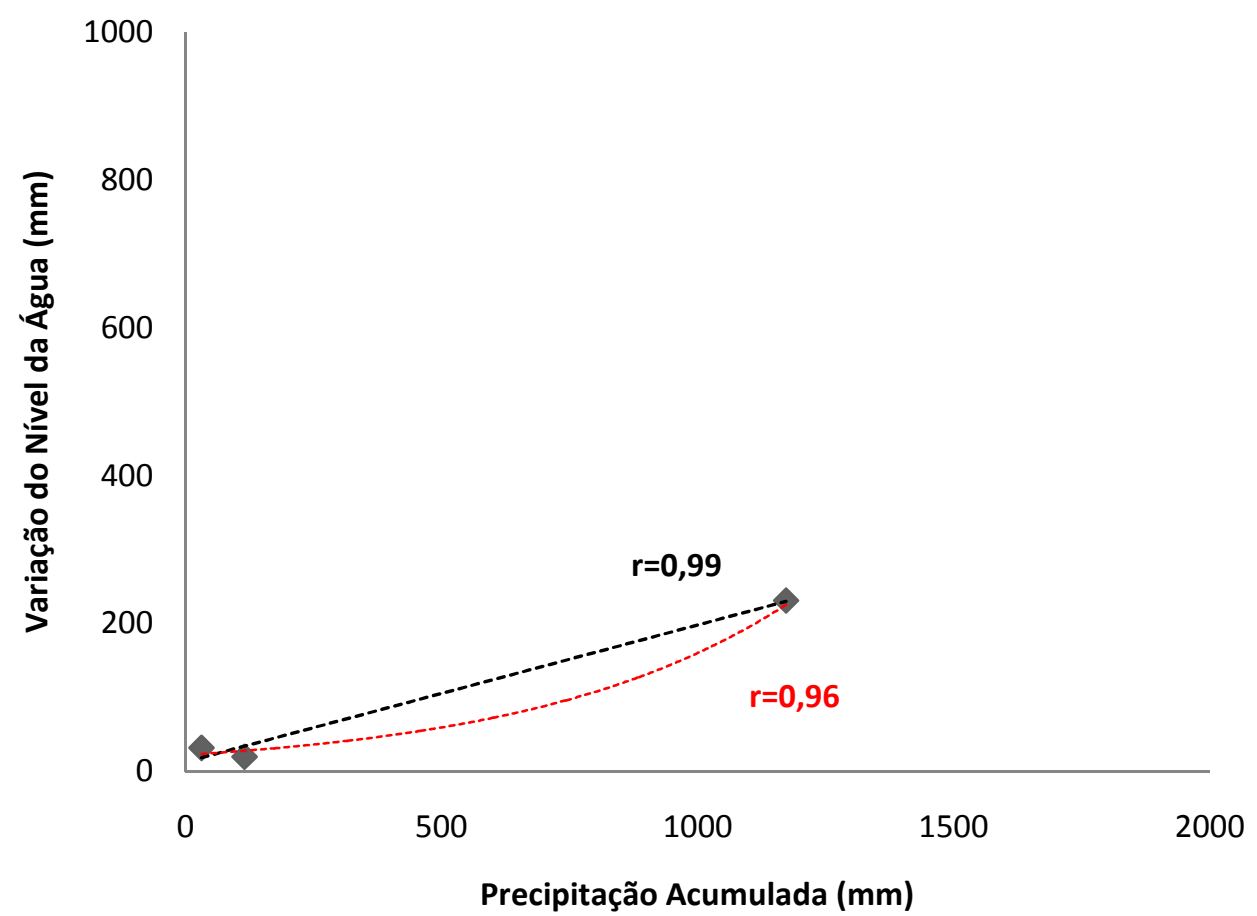

Figura 39: Correlação diária entre variação do nível d'água e precipitação acumulada no poço 10 , localizado em região de cultivo de eucaliptos, para o período de setembro de 2004 a setembro de 2008. 


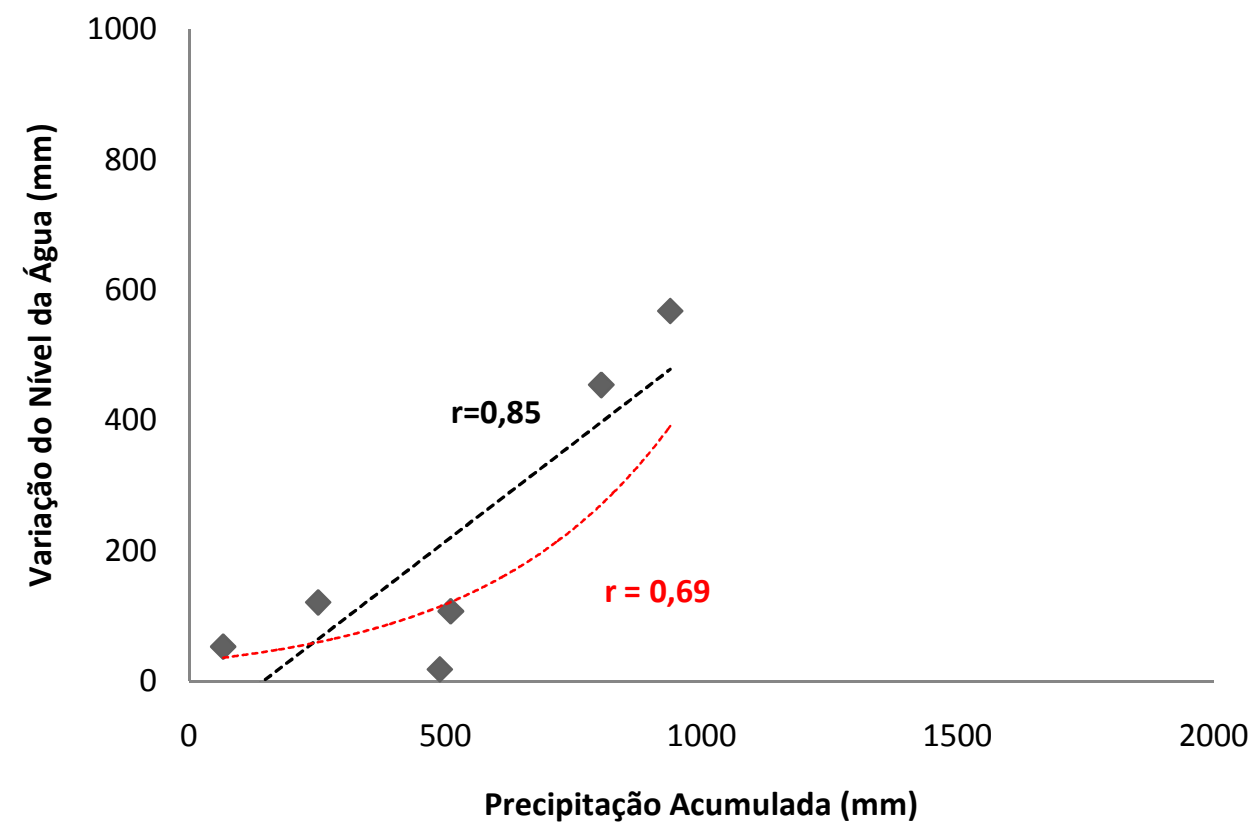

Figura 40: Correlação entre variação do nível d'água e precipitação acumulada no poço 13, localizado em região de cultivo de cítricos, para o período de setembro de 2004 a setembro de 2008.

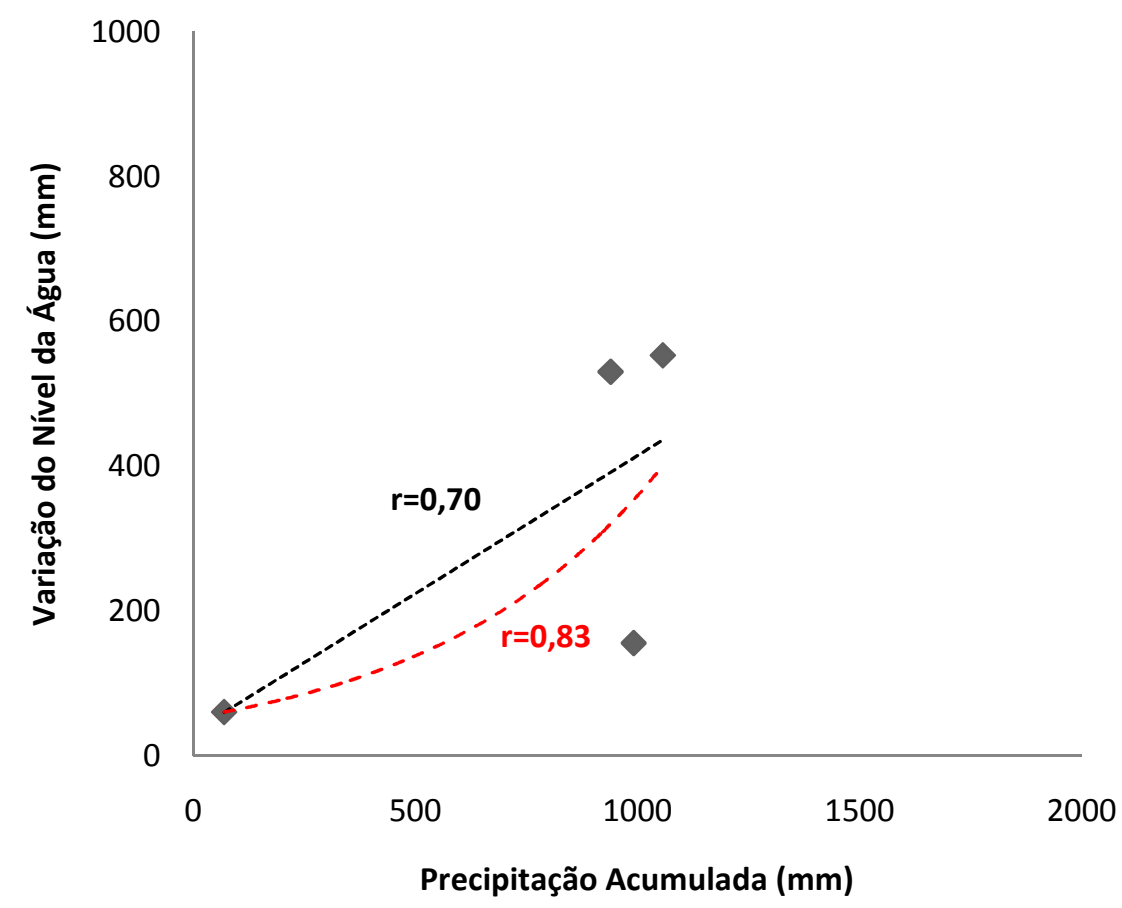

Figura 41: Correlação entre variação do nível d'água e precipitação acumulada no poço 14, localizado em região de cultivo de cítricos, para o período de setembro de 2004 a setembro de 2008. 


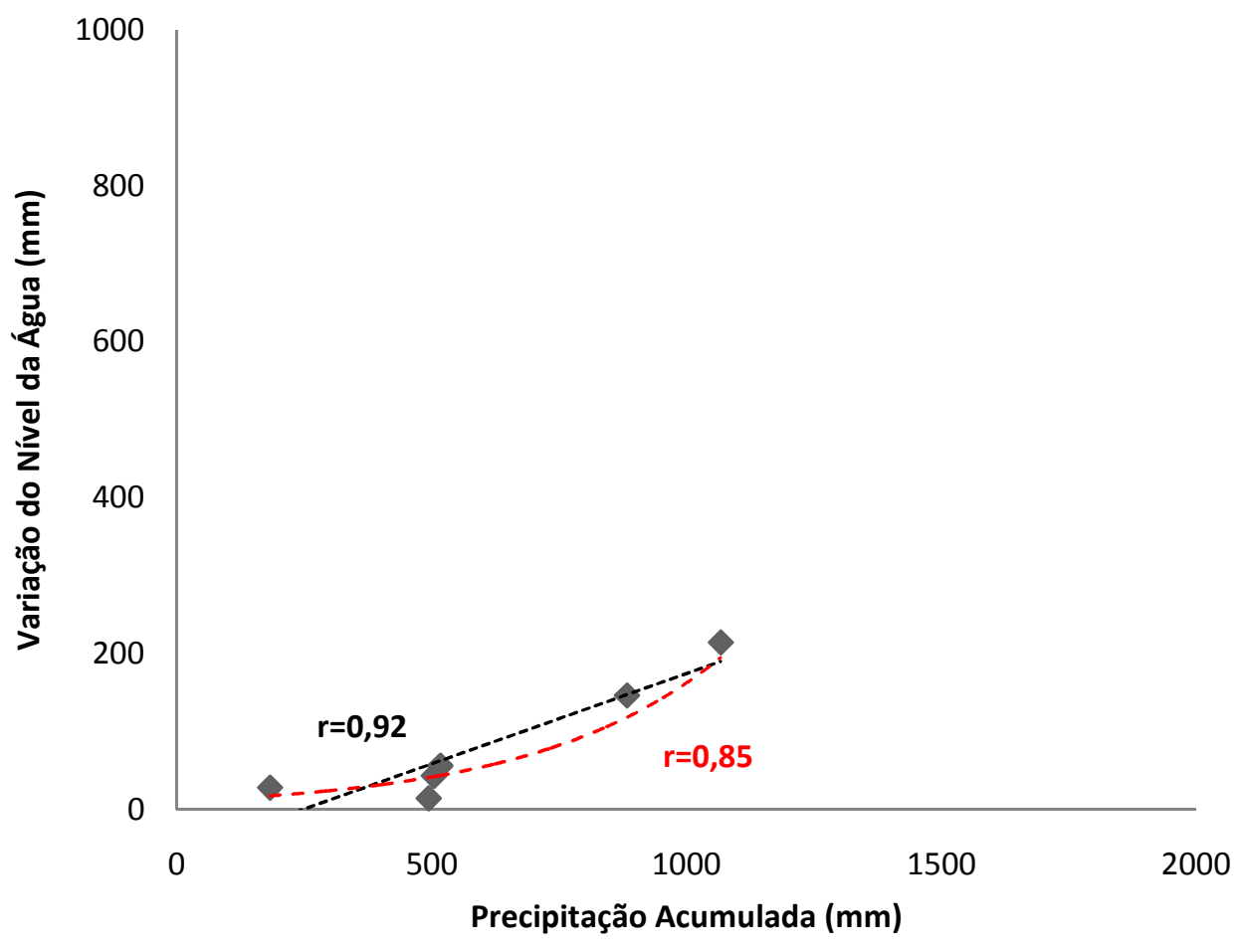

Figura 42: Correlação entre variação do nível d'água e precipitação acumulada no poço 15, localizado em região de cultivo de cana-de-açúcar, para o período de setembro de 2004 a setembro de 2008.

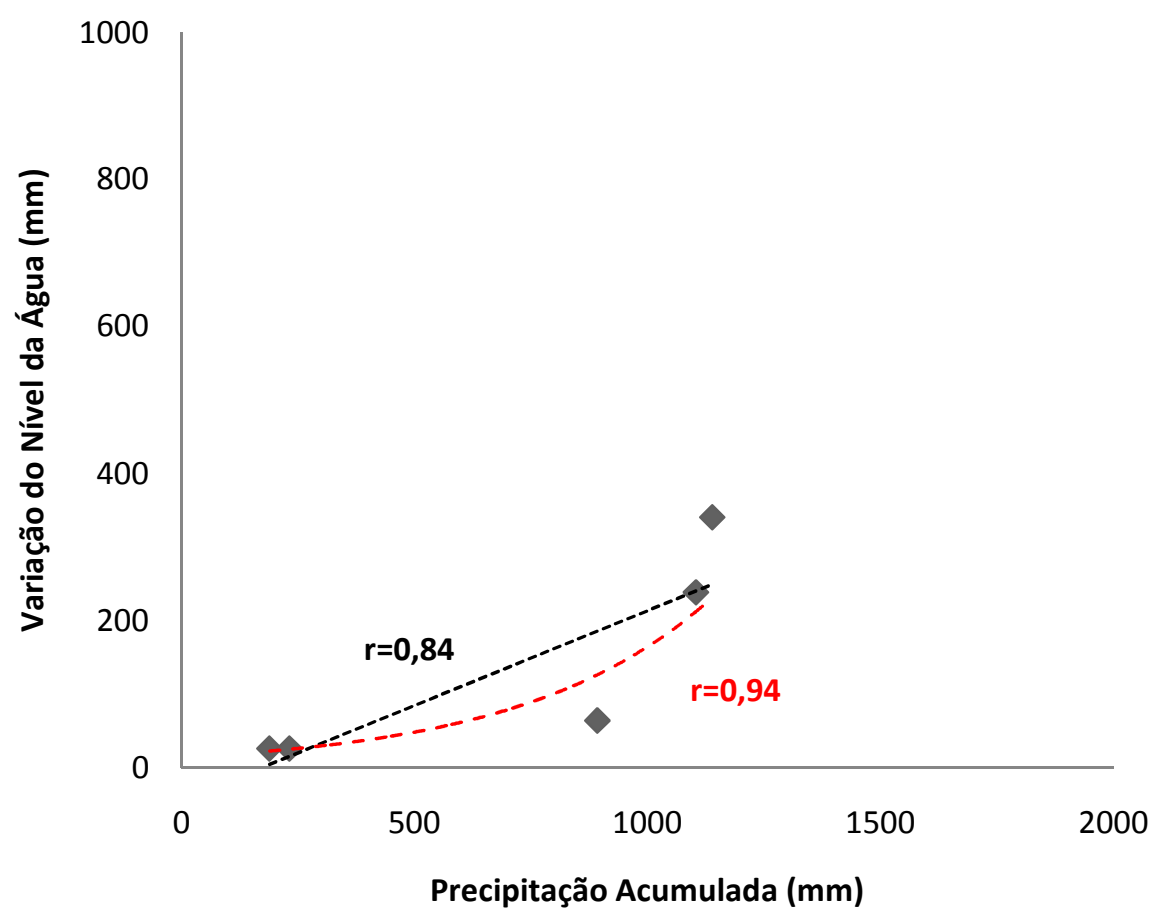

Figura 43: Correlação entre variação do nível d'água e precipitação acumulada no poço 16, localizado em região de pastagem, para o período de setembro de 2004 a setembro de 2008. 


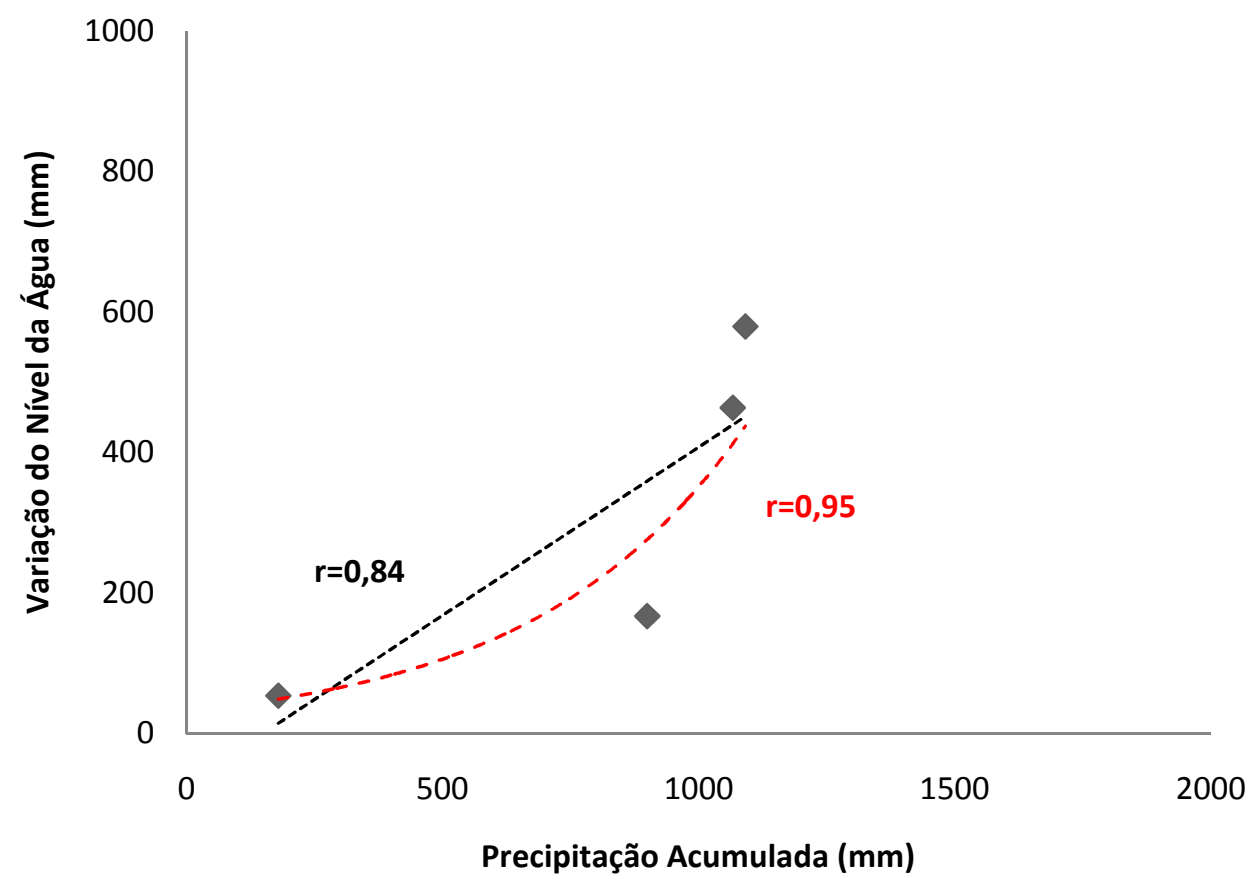

Figura 44: Correlação entre variação do nível d'água e precipitação acumulada no poço 17 , localizado em região de pastagem, para o periodo de setembro de 2004 a setembro de 2008.

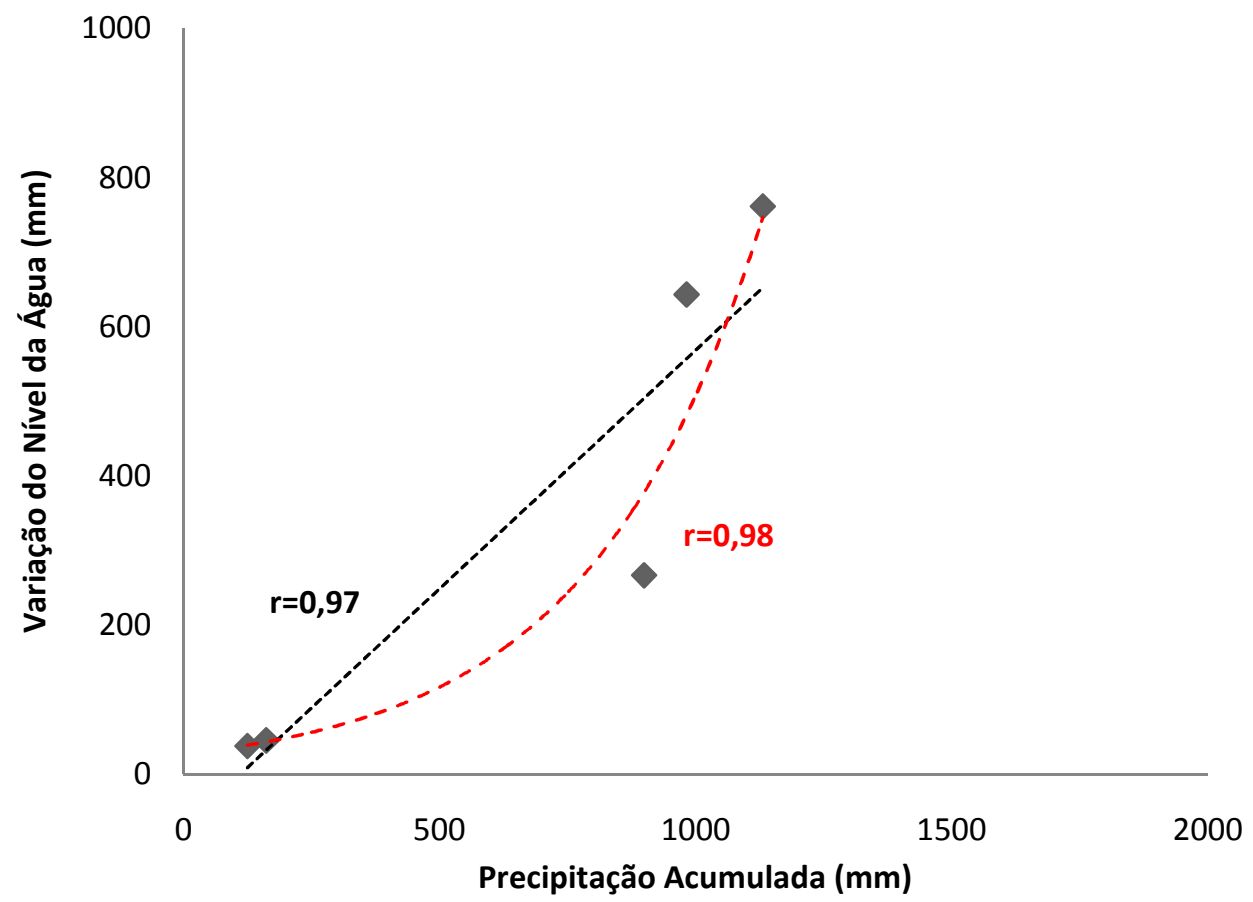

Figura 45: Correlação entre variação do nível d'água e precipitação acumulada no poço 18 , localizado em região de pastagem, para o período de setembro de 2004 a setembro de 2008 . 


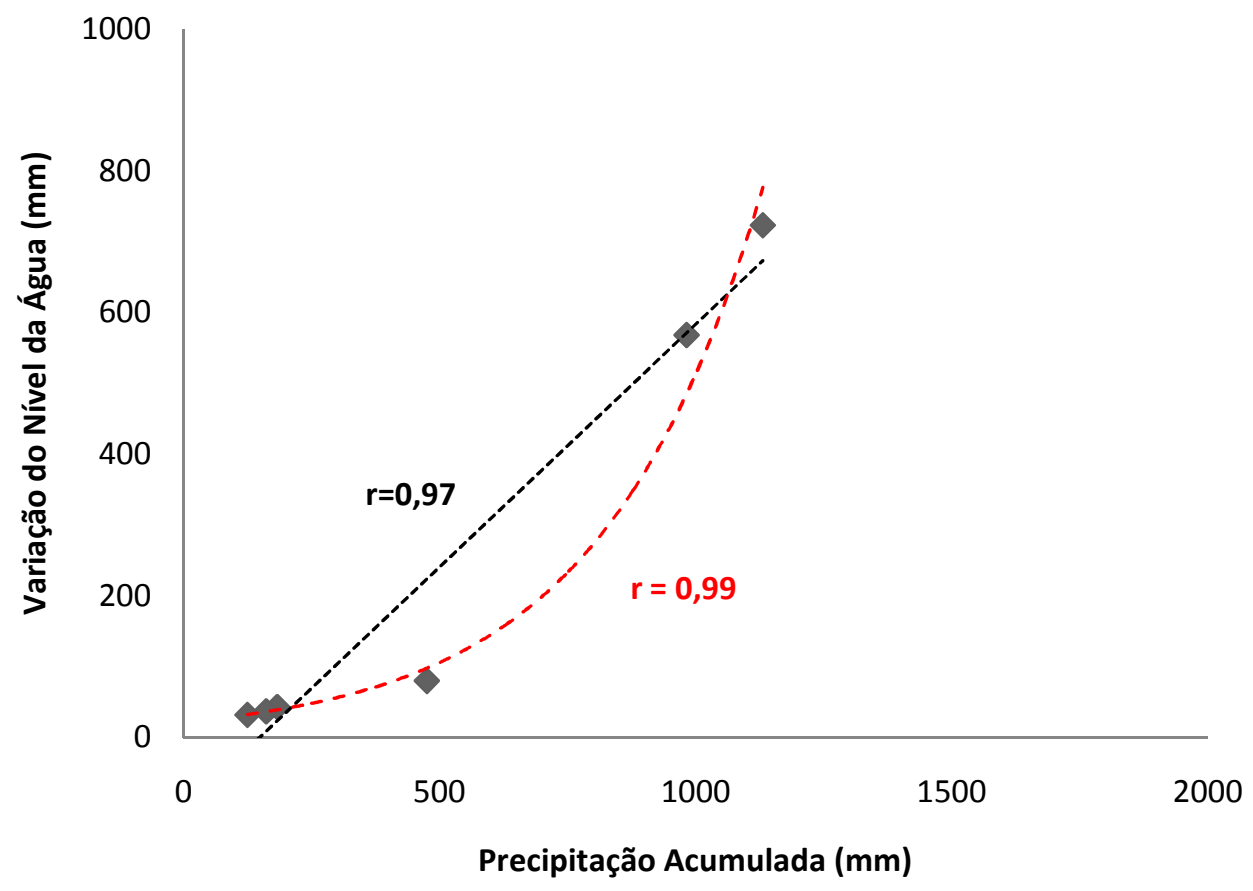

Figura 46: Correlação entre variação do nível d'água e precipitação acumuada no poço 19, localizado em região de pastagem, para o período de setembro de 2004 a setrembro de 2008.

As correlações entre a variação do nível d'água e a precipitação acumulada para o período chuvoso correspondente geraram coeficientes elevados. Esses resultados mostram que existe uma forte relação entre os fenômenos hidrológicos estudados. Os valores obtidos indicam, ainda, que há um período de defasagem entre os eventos, pois foram utilizados valores acumulados de precipitação e variações de nível d'água (somente em períodos de elevação). Comparando esses resultados com os testes iniciais (correlações com valores mensais), é possível afirmar que eventos isolados de precipitação não geram variações do nível d'água. São os valores de precipitação acumulados ao longo do tempo que determinam a elevação do nível d'água nos poços.

As correlações entre as variáveis estudadas não foram todas lineares. Para cada poço, testou-se a correlação linear e exponencial. O poço 4 , localizado em área de 
pastagem apresentou comportamento distinto. O coeficiente de correlação linear desse poço foi mais elevado. Já para o poço 5, os coeficientes resultantes das duas relações entre as variáveis foram iguais $(r=0,96)$. Esse fato pode ser explicado pela diferença de profundidade do nível d'água nesses poços. O poço 4 tem maior profundidade (aproximadamente $18 \mathrm{~m}$ ) e, portanto, o nível d'água neste responde mais lentamente aos eventos de precipitação. O mesmo ocorreu com o poço 8, cujo coeficiente de correlação linear foi $\mathrm{r}=1,0$. Este poço tem profundidade de, aproximadamente, $22 \mathrm{~m}$.

Os coeficientes de correlação linear resultantes das variáveis estudadas nos poços 9 e 10 foram mais elevados que os coeficientes exponenciais. Os poços 13 e 14, localizados em área de cultivo de cítricos, apresentaram resultados distintos. Conforme o gráfico da figura 40 nota-se que o maior coeficiente de correlação foi o linear $(\mathrm{r}=$ 0,85), enquanto que a figura 41 apresenta o gráfico do poço 14, em que o coeficiente de correlação exponencial foi mais elevado $(r=0,83)$. Novamente, esse comportamento deve estar ligado à profundidade do nível d'água no poço, pois no poço 14 atinge menor profundidade que o 13. Ressalta-se que esses poços estão localizados em áreas irrigadas, o que gera variações de nível d'água diárias mais elevadas se comparadas com os demais poços, podendo, esse fato, influenciar na relação com a precipitação.

Os poços 16, 17, 18 e 19 estão localizados em região de pastagem. Para esses poços, os coeficientes de correlação exponencial obtidos foram mais elevados.

As análises dos gráficos e coeficientes de correlação mostram que a profundidade do nível d'água no poço tem influência direta na variação do nível d'água. Isso quer dizer que poços mais rasos respondem mais rapidamente aos eventos de precipitação e, por isso, os coeficientes de correlação exponenciais resultam em valores mais elevados.

A variação do nível d'água foi definida como a variação do nível d'água em 
cada poço, corrigida a partir da multiplicação dessas variações pela porosidade da área onde o poço está localizado, e mostrou-se como fator determinante para os altos valores de coeficientes de correlação. Isso ocorreu porque essa variação considera o intervalo entre o início de recessão do nível d'água em um poço e o pico de elevação (máxima altura atingida pelo nível d'água, no período de elevação do poço). Dessa forma, foi possível detectar a existência de uma forte correlação. Ressalta-se, ainda, que a utilização de valores de precipitação acumulada ratifica que os eventos isolados de chuva produzem pouca influência na variação do nível d’água no aqüífero.

\subsubsection{Avaliação da Defasagem entre Precipitação e Variação do Nível d’Água}

Foram calculados coeficientes de correlação entre a variação do nível d'água em cada poço e a precipitação acumulada em diferentes intervalos de tempo. Conforme explanado na metodologia do trabalho, calculou-se a precipitação acumulada para 2, 3, 4, 5, 6, 7, 10, 15 e 20 dias, anteriores à elevação do nível d'água nos poços. Foram analisados apenas os períodos em que ocorreu elevação do nível d'água nos poços.

Os gráficos das figuras 47 e 48 apresentam os coeficientes de correlação em função da defasagem para os poços 4 e 5 .

O nível d'água no poço 4, localizado em área de pastagem (figura 47), durante os anos estudados atingiu a profundidade máxima de $18,4 \mathrm{~m}$, e foram detectados cinco períodos de elevação do nível d'água, os quais coincidiram com os períodos chuvosos na região (outubro a março). O primeiro período de elevação do nível d'água ocorreu entre dezembro de 2004 e fevereiro de 2005, totalizando 47 dias. Os coeficientes de correlação, entre o período de variação e as precipitações acumuladas, mais elevados foram obtidos para precipitações acumuladas de 15 dias $(r=0,73)$. O segundo período de elevação ocorreu em fevereiro de 2006, por 12 dias. Para esse intervalo de tempo, todos os coeficientes de correlação encontrados foram muito baixos. Entre dezembro de 
2006 e março de 2007, o nível d'água se elevou por 97 dias, o que gerou coeficientes de correlação bastante elevados $(0,58$ a 0,68$)$, para as precipitações acumuladas de 10 a 20 dias. Em novembro de 2007, o intervalo de tempo em que houve elevação do nível d'água foi de 14 dias, e os coeficientes de correlação obtidos para esse período foram muito baixos. O mesmo ocorreu entre os meses de janeiro e março de 2008, em que houve elevação do nível d'água por 64 dias.

\section{Poço 4 - Pastagem ( 17,25 m)}

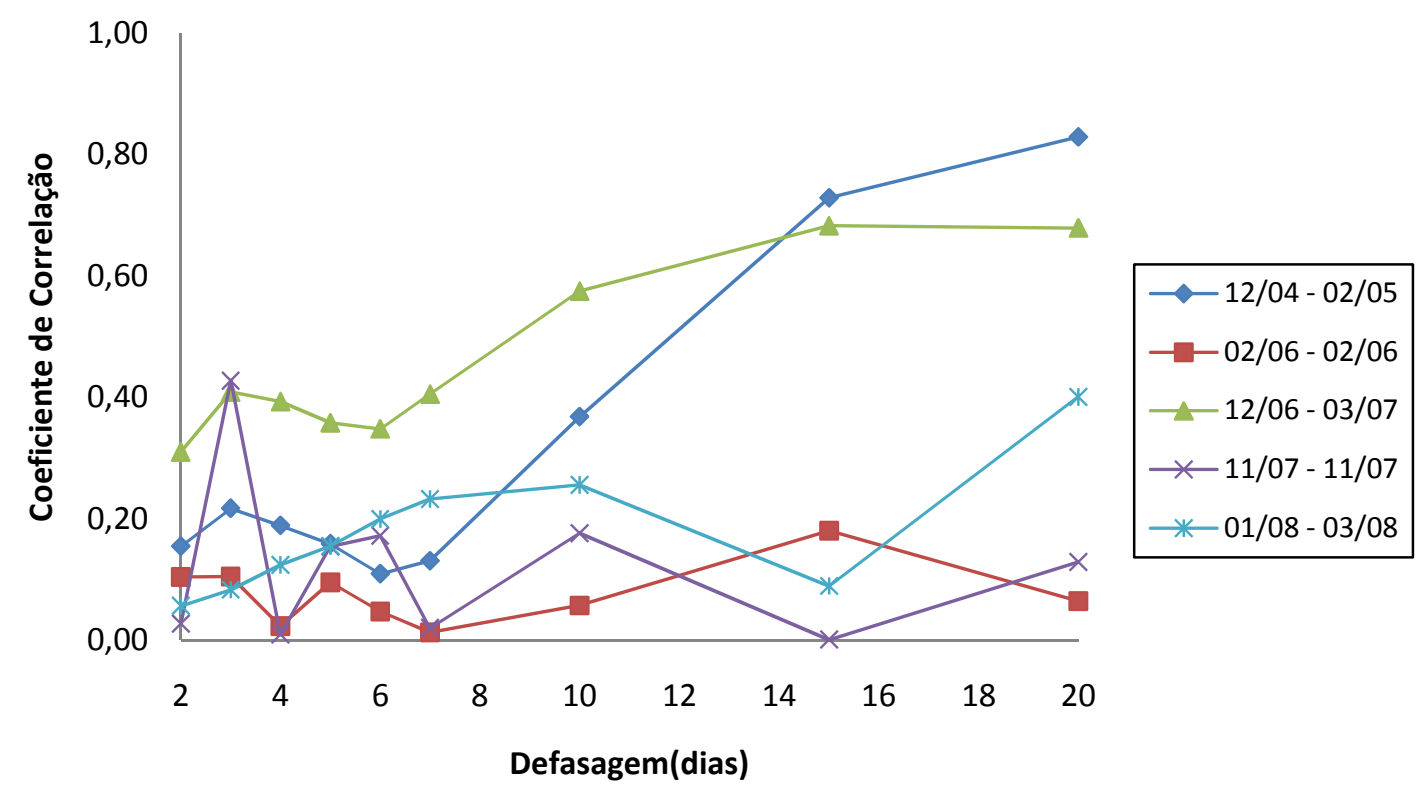

Figura 47: Coeficiente de correlação em função de diferentes defasagens de tempo para acumulação de precipitação anterior à variação de nível no poço 4.

Para o poço 5, localizado em área de pastagem (figura 48), o nível d’água atingiu a profundidade máxima de $8,29 \mathrm{~m}$. Foram encontrados nove períodos de elevação do nível d'água. Os períodos de elevação mais longos, que coincidiram com as épocas de maiores taxas pluviométricas da região, quando correlacionados com as precipitações acumuladas, geraram coeficientes mais elevados $(0,5$ a 0,9$)$ para defasagens de 10, 15 e 20 dias. Nesse poço foram notados alguns períodos curtos (até 20 dias) de elevação do nível d'água, o que pode ser explicado por sua pouca 
profundidade o que, conseqüentemente implica em respostas mais rápidas aos fenômenos de precipitação.

\section{Poço 5 - Pastagem ( 6,54 m)}

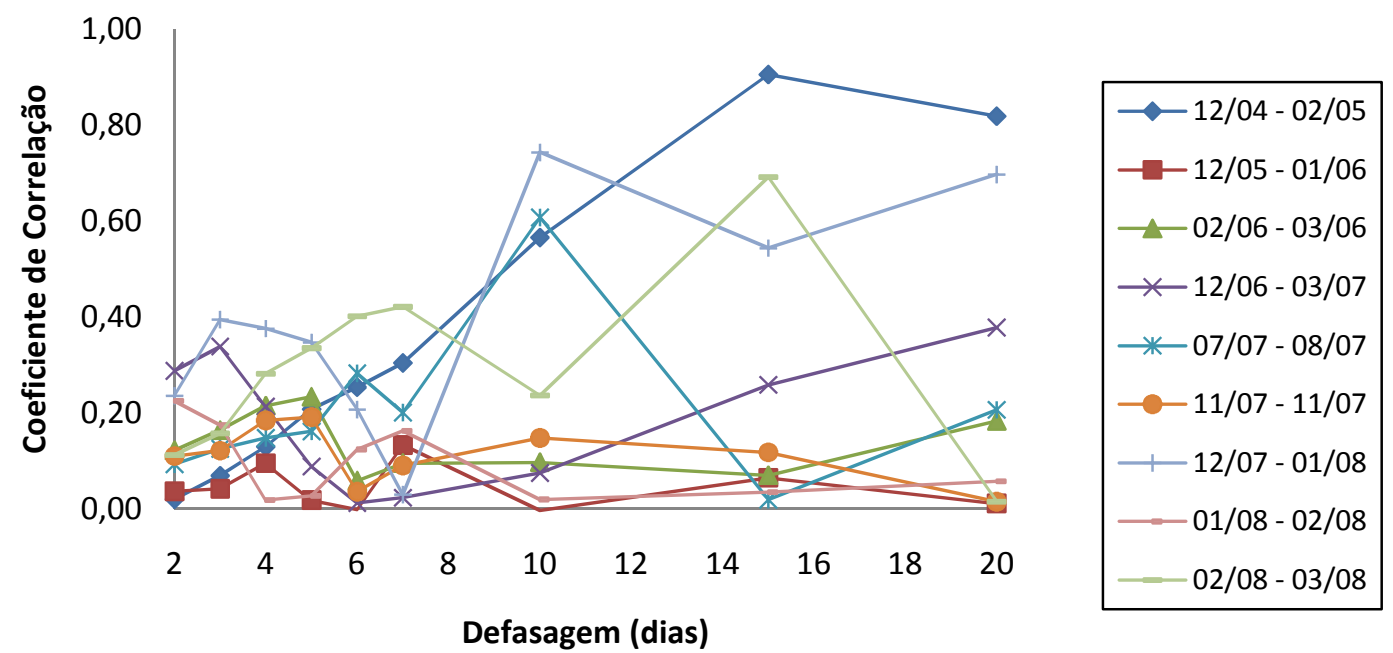

Figura 48: Coeficiente de correlação em função de diferentes defasagens de tempo para acumulação de precipitação anterior à variação de nível no poço 5.

O poço 8 , representado na figura 49, até o primeiro semestre de 2006 estava localizado em área de cultivo de cítricos, no entanto a partir do segundo semestre do ano citado, passou-se a cultivar cana-de-açúcar na região. Nos anos estudados, o nível d'água no poço atingiu profundidade máxima de $25,5 \mathrm{~m}$ e, foram encontrados nove períodos de elevação do nível d'água. Para esse poço foram verificados noves períodos de elevação do nível d'água. Os coeficientes de correlação mais elevados $(0,5$ a 0,9$)$ foram encontrados para defasagens de 10,15 e 20 dias. 


\section{Poço 8 - Cana de Açúcar (22,68 m)}

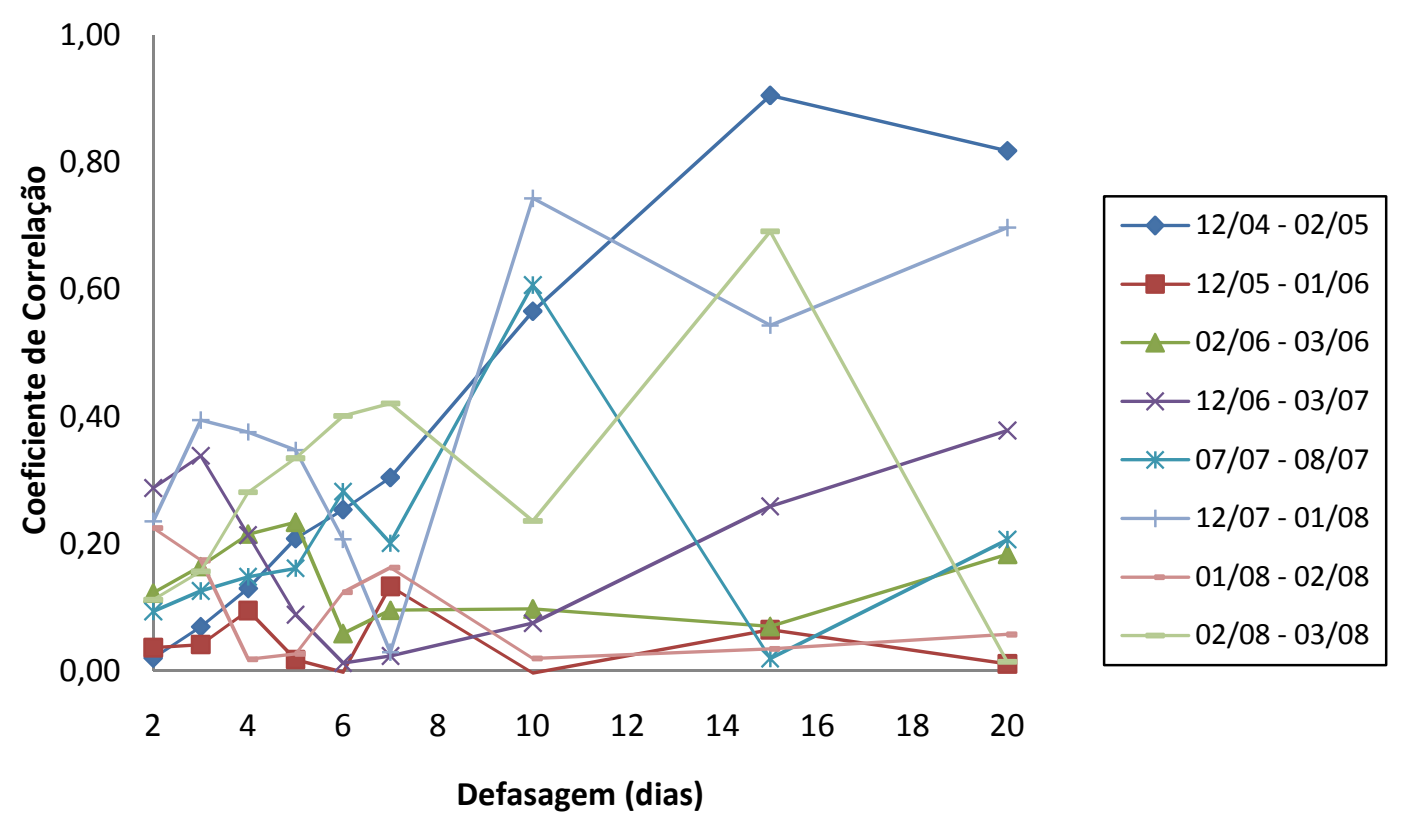

Figura 49: Coeficiente de correlação em função de diferentes defasagens de tempo para acumulação de precipitação anterior à variação de nível no poço 8.

As figuras 50 e 51 apresentam os coeficientes de correlação para os poços 9 e

10. O poço 9 está localizado em região de cultivo de eucalipto. Durante os anos estudados, o nível d'água atingiu a profundidade máxima de 23,9 m, e entrou em fase de elevação apenas em janeiro de 2007, se estendendo até maio desse mesmo ano, totalizando 108 dias. O segundo período de elevação ocorreu em julho de 2007, por 10 dias. Em março de 2008, o nível d'água voltou a elevar, até setembro desse ano. Para todos os períodos de elevação, os coeficientes de correlação encontrados foram muito baixos $(r<0,4)$. Os baixos valores dos coeficientes podem ser explicados pelo fato de que os períodos de elevação do nível d'água no poço ter ocorrido em períodos de estiagem (sem precipitação).

O poço 10 também está localizado em região de cultivo de eucalipto, e o nível d'água atingiu profundidade máxima de 21,6 m. Foram detectados dois períodos de elevação do nível d'água, ocorridos entre abril e agosto de 2007 e, abril e agosto de 
2008. Os valores dos coeficientes de correlação, para todas as precipitações acumuladas utilizadas foram baixos, com exceção dos coeficientes resultantes da relação entre o ultimo período de elevação (abril a agosto de 2008) e as precipitações acumuladas de 15 e 20 dias $(r=0,51$ e $r=0,60)$. Os gráficos das figuras 50 e 51 apresentam o comportamento dos coeficientes de correlação dos poços 9 e 10.

Poço 9 - Eucalipto ( 21,58 m)

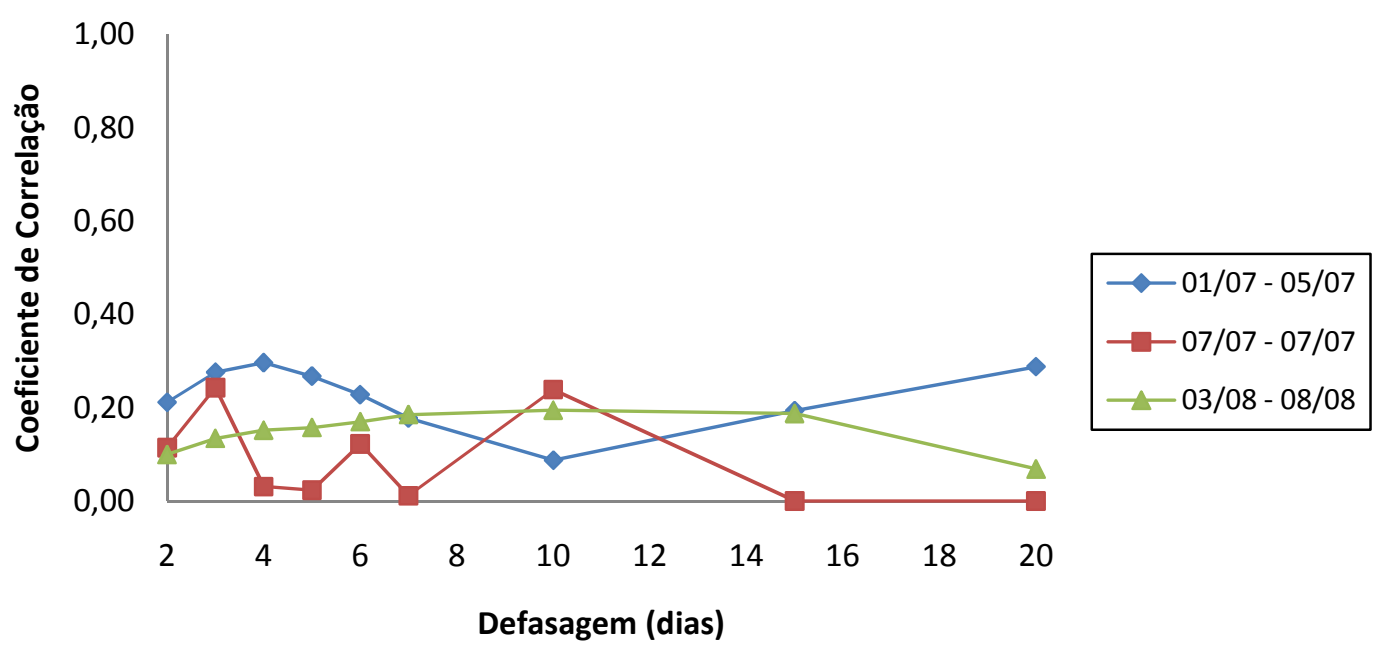

Figura 50: Coeficiente de correlação em função de diferentes defasagens de tempo para acumulação de precipitação anterior à variação de nível no poço 9.

\section{Poço 10 - Eucalipto $(20,29 \mathrm{~m})$}

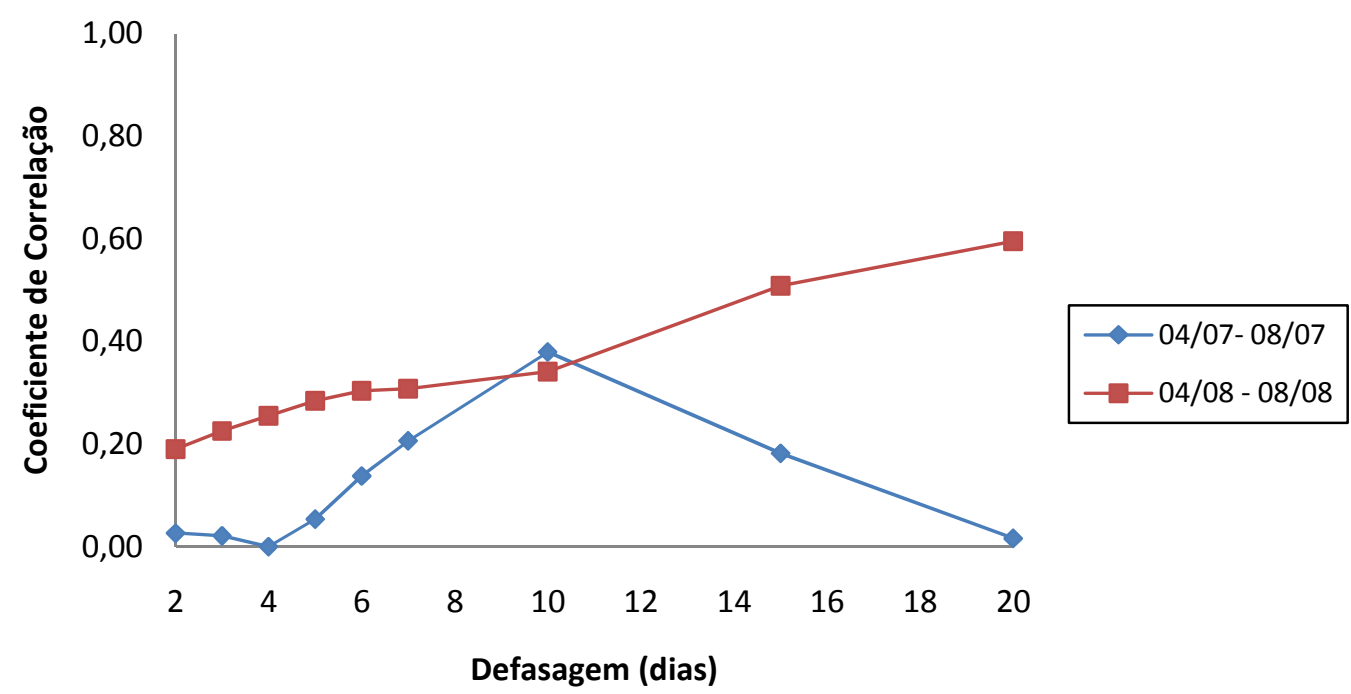

Figura 51: Coeficiente de correlação em função de diferentes defasagens de tempo para acumulação de precipitação anterior à variação de nível no poço 10. 


\section{Poço 13 - Cítricos ( 9,87 m)}

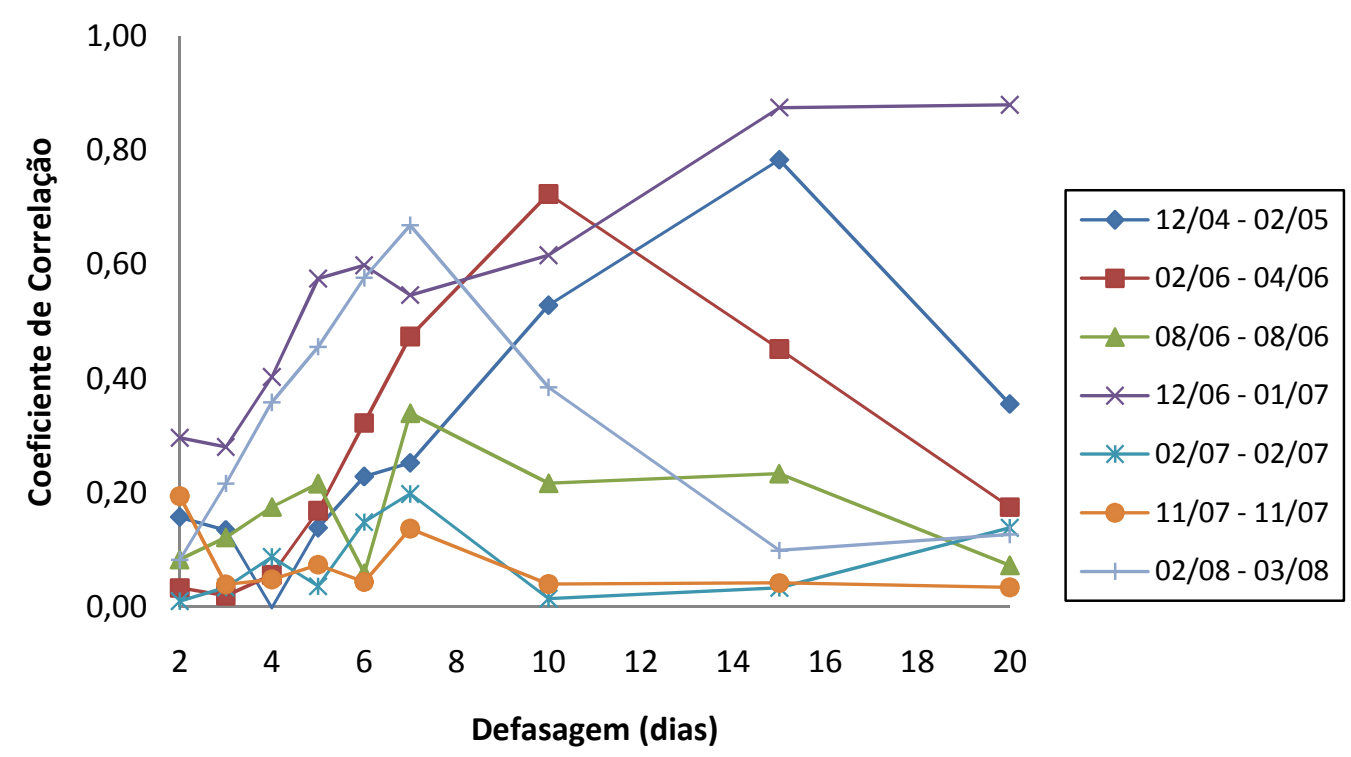

Figura 52: Coeficiente de correlação em função de diferentes defasagens de tempo para acumulação de precipitação anterior à elevação de nível no poço 13.

A figura 52 apresenta o gráfico do poço 13, localizado em área de cultivo de cítricos. O nível d'água no poço 13 (figura 52) atingiu profundidade máxima de 11,04 m, passando por seis períodos de elevação, os quais coincidem com as épocas chuvosas. As variações do nível d'água do primeiro período, ocorrido entre dezembro de 2004 e fevereiro de 2005 (47 dias), quando correlacionadas às precipitações acumuladas geraram coeficientes altos para as defasagens de 10 e 15 dias $(r=0,53$ e $r=0,78)$. É importante ressaltar uma particularidade notada nesse poço. As variações diárias do nível d'água são significativas se comparadas aos demais poços. Essa variação $(\Delta h)$ é da ordem de 0,01 m (para os poços já citados), no poço 13 foi igual a 0,13 m, 0,04 m e 0,07 m, para o primeiro período. O segundo período de elevação, ocorrido entre fevereiro e abril do ano de 2006 (63 dias) resultou em coeficiente significativo para as precipitações acumuladas de $10(\mathrm{r}=0,72)$ dias. Nesse período, a variação diária do nível d'água foi estável $(\Delta \mathrm{h}=0,01 \mathrm{~m})$. O terceiro período de elevação ocorreu em junho de 
2006, e os coeficientes de correlação obtidos foram baixos $(r<0,4)$ para todas as defasagens. Entre dezembro de 2006 e janeiro de 2007 (39 dias), com variações diárias de $0,01 \mathrm{~m}, 0,07 \mathrm{~m}$ e $0,15 \mathrm{~m}$. Para esse período foram obtidos altos coeficientes de correlação $(0,5$ a 0,8) para as defasagens de 5 a 20 dias. Em fevereiro de 2007 ocorreu uma elevação do nível d'água por 13 dias, em que a variação diária foi de 0,06 m, e os coeficientes de correlação foram muito baixos (menores que 0,2). Esse fato se repetiu em novembro de 2007 (14 dias de elevação), onde a variação diária foi de 0,01 m. O ultimo período de elevação do nível d'água detectado para o poço 13 ocorreu entre fevereiro e março de 2008 (42 dias), em que as variações diárias foram de 0,01 m, 0,03 $\mathrm{m}$ e $0,05 \mathrm{~m}$. Os valores mais altos de correlação foram encontrados para as precipitações acumuladas de $6,(r=0,58)$ e $7(r=0,67)$ dias.

O nível d'água no poço 14 (figura 53) atingiu uma profundidade máxima de 7,82 m. Foram detectados seis períodos de elevação do nível d'água, os quais coincidiram com as épocas de altas taxas pluviométricas na região. Entre dezembro de 2004 e fevereiro de 2005 (47 dias) houve o primeiro período de elevação do nível d'água, em que as variações diárias foram de $0,16 \mathrm{~m}, 0,04 \mathrm{~m}$ e 0,02m. Os coeficientes de correlação obtidos foram baixos, atingindo o valor máximo de $\mathrm{r}=0,48$ para uma defasagem de 20 dias. Em 2006, entre fevereiro e abril (42 dias), as elevações diárias do nível d’água foram de $0,02 \mathrm{~m}$ e $0,01 \mathrm{~m}$. Foram obtidos altos coeficientes de correlação para defasagens de 10 e 15 dias (0,77 e 0,5). Em agosto de 2006 iniciou-se o terceiro período de elevação do nível d'água, em que as variações diárias foram de 0,12 m e 0,07 m. Todos os coeficientes de correlação foram baixos $(r<0,3)$. Entre dezembro de 2006 e janeiro de 2007, houve um período de elevação do nível d'água de 47 dias, em que foram obtidos altos coeficientes de correlação $(0,5$ a 0,8) para defasagens de 5 a 20 dias. No mês de fevereiro de 2007 ocorreu um pequeno período de elevação do nível d'água, 
mas não foram encontrados coeficientes de correlação altos (todos abaixo de 0,3 ). $\mathrm{O}$ mesmo foi encontrado para novembro de 2007 e janeiro a março de 2008.

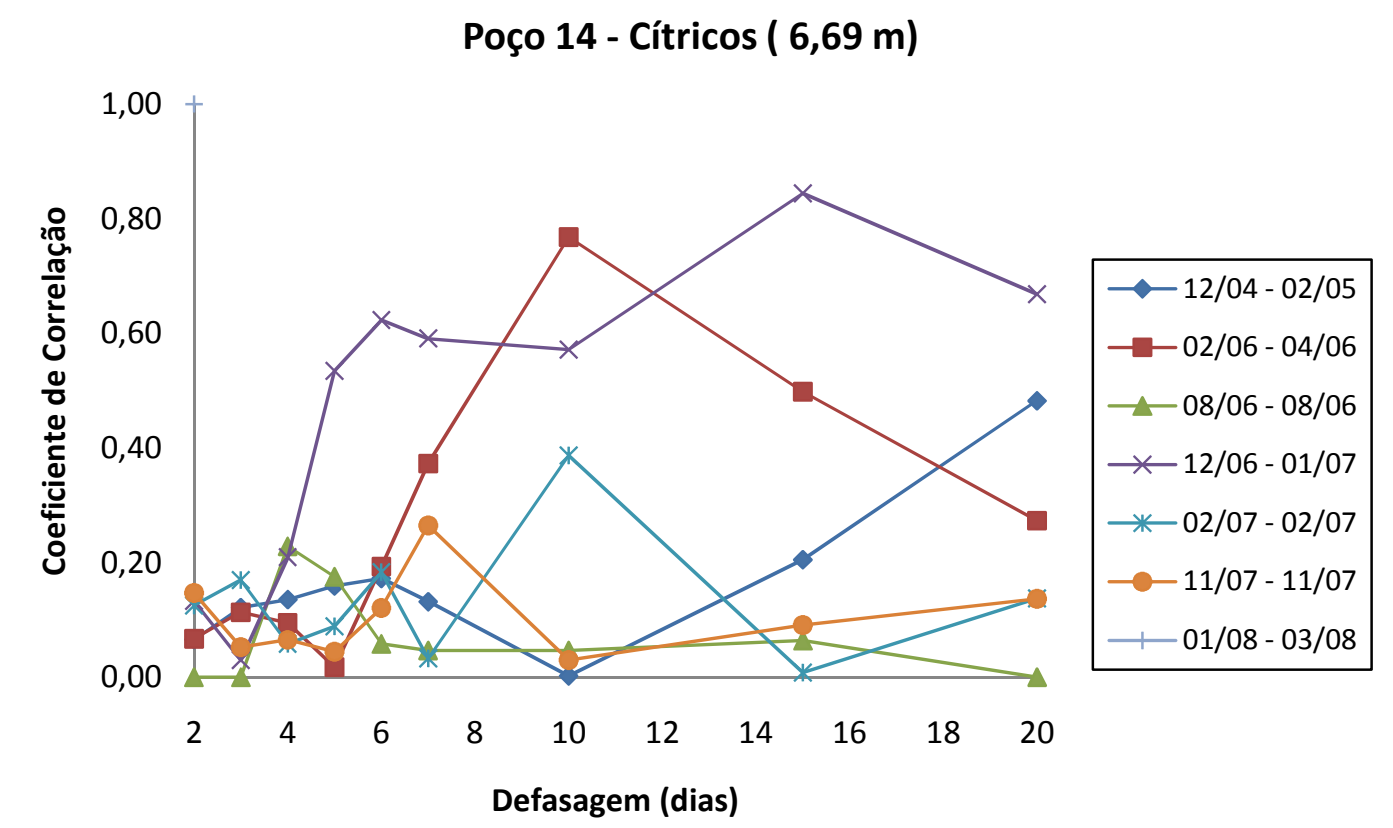

Figura 53: Coeficiente de correlação em função de diferentes defasagens de tempo para acumulação de precipitação anterior à elevação de nível no poço 14.

O poço 15 (figura 54), até o final do primeiro semestre de 2006, estava localizado em área de cultivo de cana-de-açúcar. A partir do segundo semestre do ano citado, na área de sua localização passou-se a realizar o cultivo de cítricos. O nível d'água neste poço atingiu profundidade máxima de 9,74 m, e nele ocorreram seis períodos de elevação do nível d'água. O primeiro deles teve duração de 48 dias, ocorrido entre dezembro de 2004 e fevereiro de 2005. As variações diárias desse poço também não são estáveis, e para os dias citados foram de $0,07 \mathrm{~m}, 0,09 \mathrm{~m}$ e $0,04 \mathrm{~m}$. Os maiores coeficientes de correlação para essa série foram de 0,58 e 0,83, para defasagens de 10 e 15 dias. Entre março e abril de 2006, a elevação do nível d'água ocorrida não gerou coeficientes de correlação altos para nenhuma das precipitações 
acumuladas utilizadas (todos abaixo de 0,2 ). O terceiro período ocorreu entre dezembro de 2006 e janeiro de 2007 (27 dias), em que as variações diárias foram de 0,06 m e 0,03 $\mathrm{m}$, as quais geraram melhores coeficientes de correlação com precipitações acumuladas de $5(r=0,53), 6(r=0,62), 7,(r=0,59), 10(r=0,57), 15(r=0,84)$ e $20(r=0,67)$ dias. As elevações ocorridas em março e novembro de 2007 geraram coeficientes de correlação muito baixos para todas as precipitações acumuladas. O mesmo ocorreu para o período de janeiro e março de 2008, com exceção do coeficiente obtido para defasagem de 15 dias, que foi de 0,69 .

Poço 15 - Citrícos ( 7,95 m)

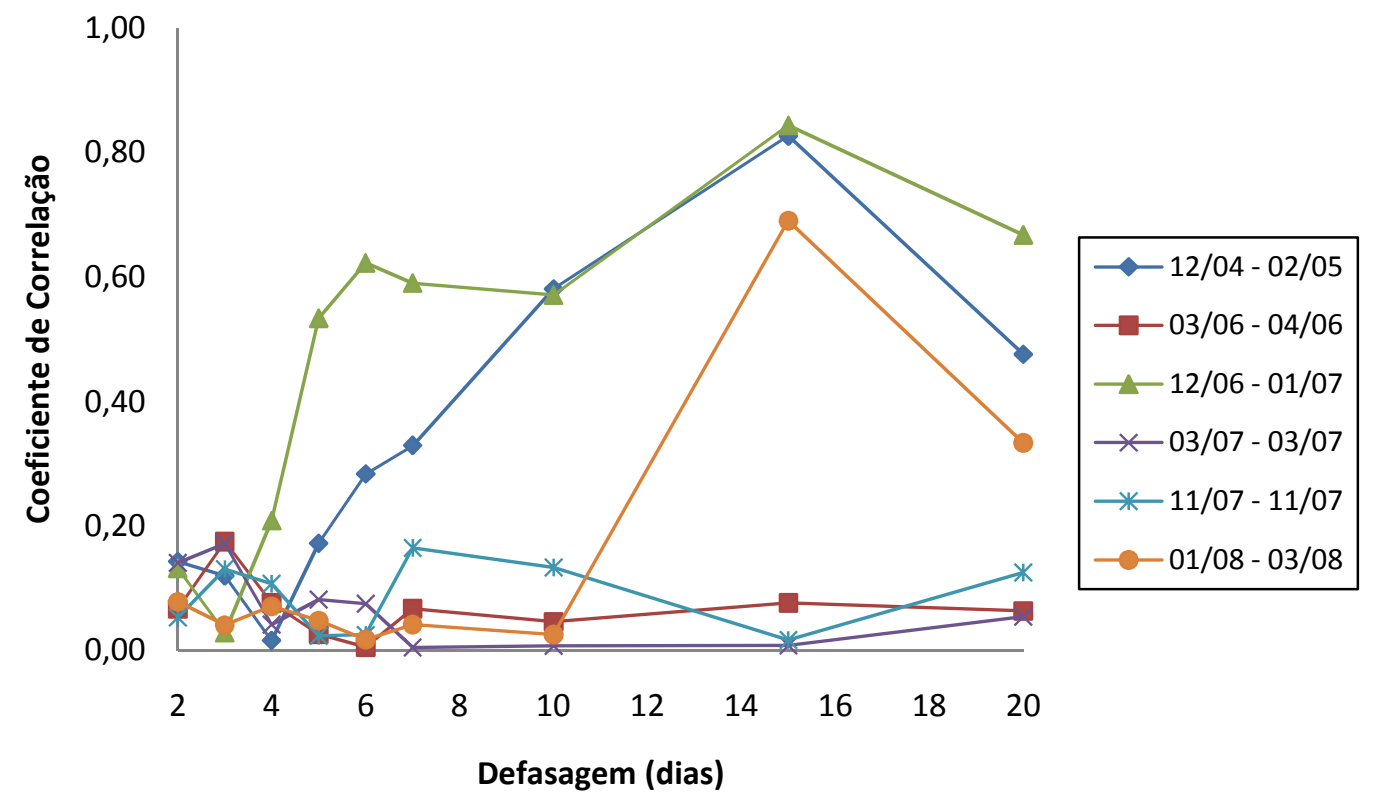

Figura 54: Coeficiente de correlação em função de diferentes defasagens de tempo para acumulação de precipitação anterior à elevação de nível no poço 15.

Os poços 16, 17, 18 e 19 estão localizados em região de pastagem Os níveis d'água dos mesmos atingiram profundidades máximas de 6,24 m, 12,86 m, 16,4 m e $17,15 \mathrm{~m}$, respectivamente.

No poço 16, apresentado na figura 55, foram detectados sete períodos de elevação do nível d'água. Por 60 dias, entre dezembro de 2004 e janeiro de 2005, houve 
elevações de nível d'água de $0,01 \mathrm{~m}$ e $0,11 \mathrm{~m}$. Os coeficientes de correlação encontrados para as defasagens de 7 a 20 dias foram altos (entre 0,5 e 0,78). O segundo período, ocorrido em março de 2005, não gerou coeficientes de correlação altos com nenhuma das precipitações acumuladas. O mesmo ocorreu para os meses de março e abril de 2006, onde os coeficientes de correlação não foram maiores de 0,2. Entre dezembro de 2006 e fevereiro de 2007, houve um período de elevação do nível d'água de 74 dias, em que as variações diárias foram de 0,02 m, 0,08 m, 0,13 m, 0,15 m e 0,16 m. Apesar do longo período de elevação e da alta variação foram obtidos coeficientes de correlação elevados para defasagens menores, de 3 a 7 dias ( entre 0,6 e 0,7). Os demais períodos de elevação do nível d'água também não geraram coeficientes de correlação muito elevados, com algumas exceções: entre dezembro e fevereiro de 2007, em que a variação diária foi de $0,02 \mathrm{~m}$, e o coeficiente para uma precipitação acumulada de 20 dias foi de 0,54 , e ente janeiro e março de 2008, em que os coeficientes mais elevados foram obtidos para defasagens de 5, 6, e 7 dias $(0,52,0,52$ e 0,59 , respectivamente).

\section{Poço 16 - Pastagem (5,08 m)}

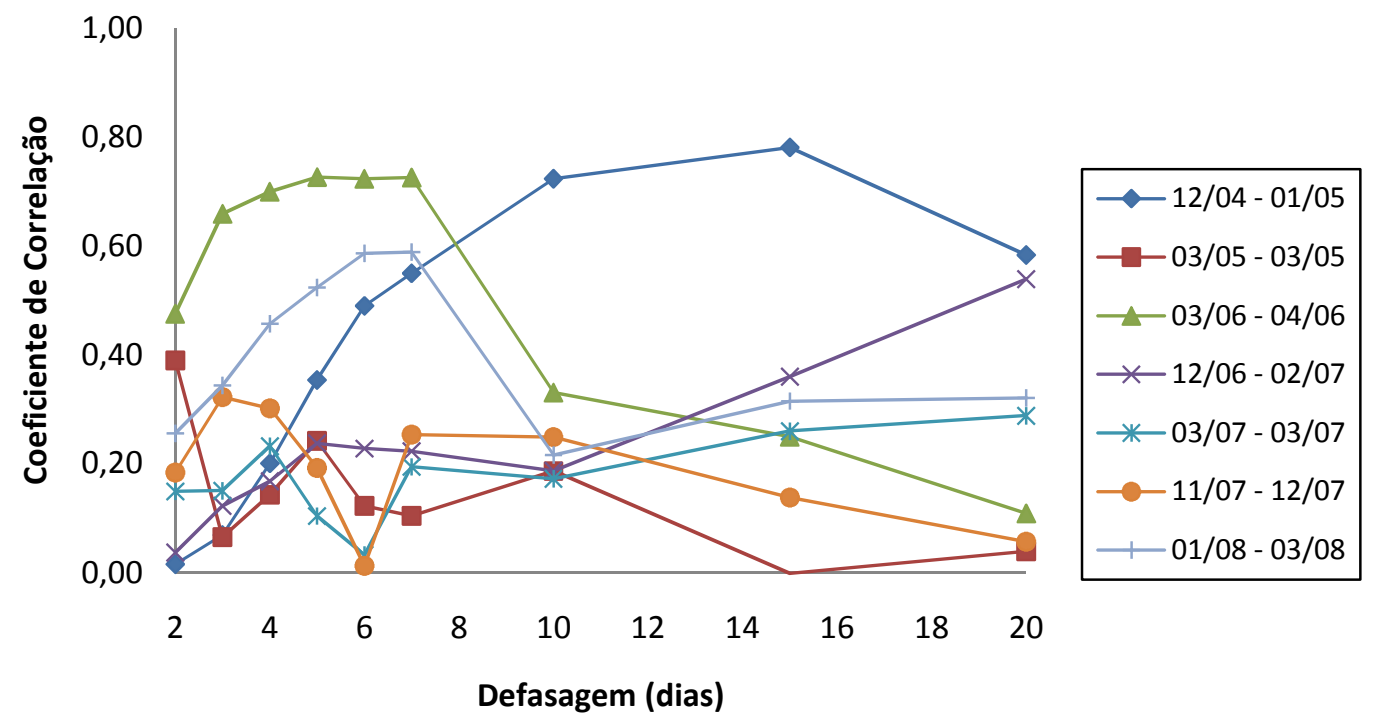

Figura 55: Coeficiente de correlação em função de diferentes defasagens de tempo para acumulação de precipitação anterior à elevação de nível no poço 16. 
No poço 17 (figura 56) ocorreram cinco períodos de elevação do nível d'água. Entre dezembro de 2004 e fevereiro de 2005 as variações diárias, correspondentes a elevação do nível, foram de $0,05 \mathrm{~m}$ e $0,31 \mathrm{~m}$, no entanto para todas as precipitações acumuladas utilizadas, os coeficientes encontrados foram baixos (menores que 0,3). A mesma situação se repetiu entre janeiro e abril de 2006 ( $\mathrm{r}<0,4)$. Em dezembro de 2006 iniciou-se um novo período de elevação, que se estendeu até fevereiro de 2007, com variações diárias de $0,01 \mathrm{~m}, 0,07 \mathrm{~m}$ e $0,18 \mathrm{~m}$. Os coeficientes de correlação encontrados para essa série foram mais altos quando relacionados às precipitações de $5(\mathrm{r}=0,55)$ e 6 $(\mathrm{r}=0,55)$ dias. Os demais períodos de elevação, quando correlacionados as precipitações acumuladas defasadas não geraram coeficientes de correlação maiores que 0,4 .

Poço 17 - Pastagem ( 11,00 m)

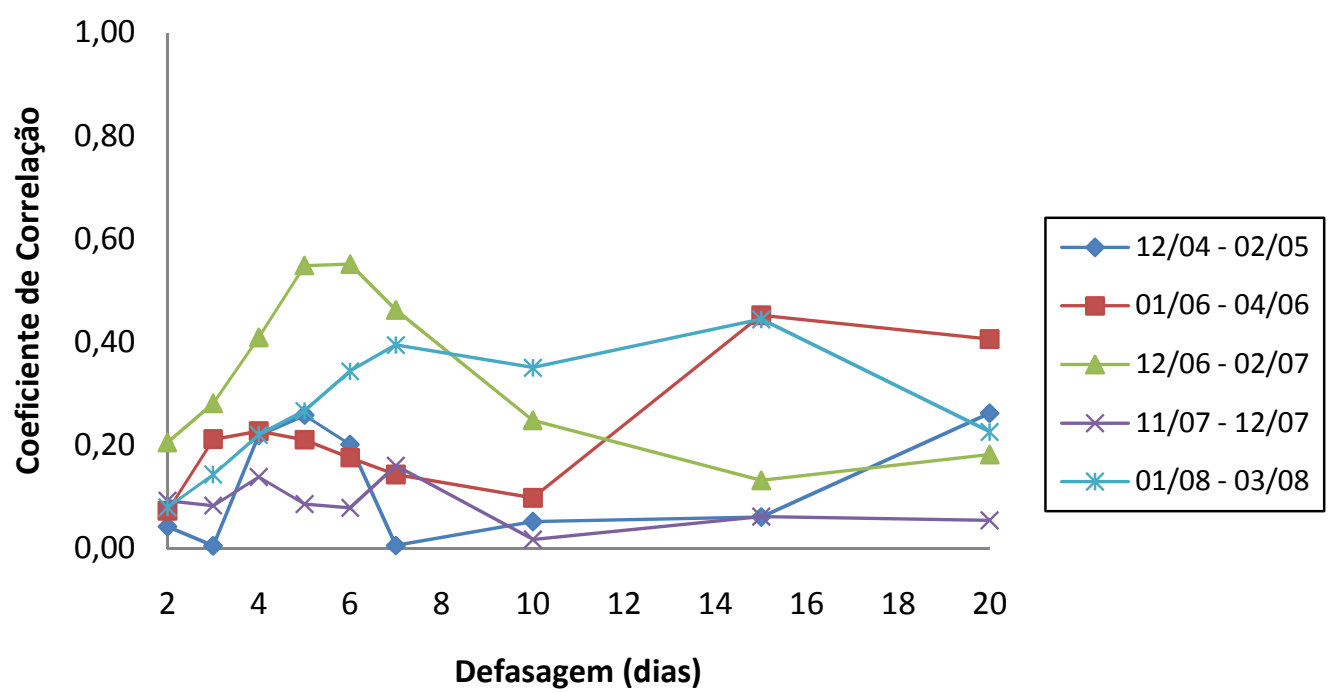

Figura 56: Coeficiente de correlação em função de diferentes defasagens de tempo para acumulação de precipitação anterior à elevação de nível no poço 17.

O nível d'água no poço 18 passou por seis períodos de elevação. O primeiro deles ocorreu entre dezembro de 2004 e fevereiro de 2005, e teve variações diárias altas de $0,03 \mathrm{~m}, 0,08 \mathrm{~m}$ e $0,95 \mathrm{~m}$. No entanto, não foram gerados altos coeficientes de 
correlação para nenhuma das precipitações acumuladas. Em janeiro de 2006 ocorreu a segunda elevação do nível d'água, que se estendeu até maio de 2006, totalizando 121 dias, em que as variações diárias foram de $0,01 \mathrm{~m}$. Para essa série o coeficiente de correlação mais alto encontrado foi de 0,37 , para precipitações acumuladas de 4 e 5 dias. Entre dezembro de 2006 e março de 2007 houve um período de elevação do nível d'água de 73 dias, com variações diárias de $0,02 \mathrm{~m}, 0,04 \mathrm{~m}, 0,10 \mathrm{~m}$ e 0,27 m. Para precipitações de 5 e 6 dias foram obtidos os coeficientes de correlação mais altos $(\mathrm{r}=$ 0,51). Em abril e dezembro de 2007 ocorreram dois curtos períodos de elevação, os quais não produziram coeficientes de correlação elevados para nenhuma das precipitações acumuladas. Entre janeiro e março de 2008, o nível d'água se elevou por 63 dias, com variações diárias de $0,02 \mathrm{~m}, 0,03 \mathrm{~m}$ e 0,06 m. Para essa série de dados, a mais alta correlação foi obtida para uma defasagem de $7(\mathrm{r}=0,51)$ dias. A figura 57 apresenta os coeficientes de correlação obtidos para esse poço.

\section{Poço 18 - Pastagem $(13,68 \mathrm{~m})$}

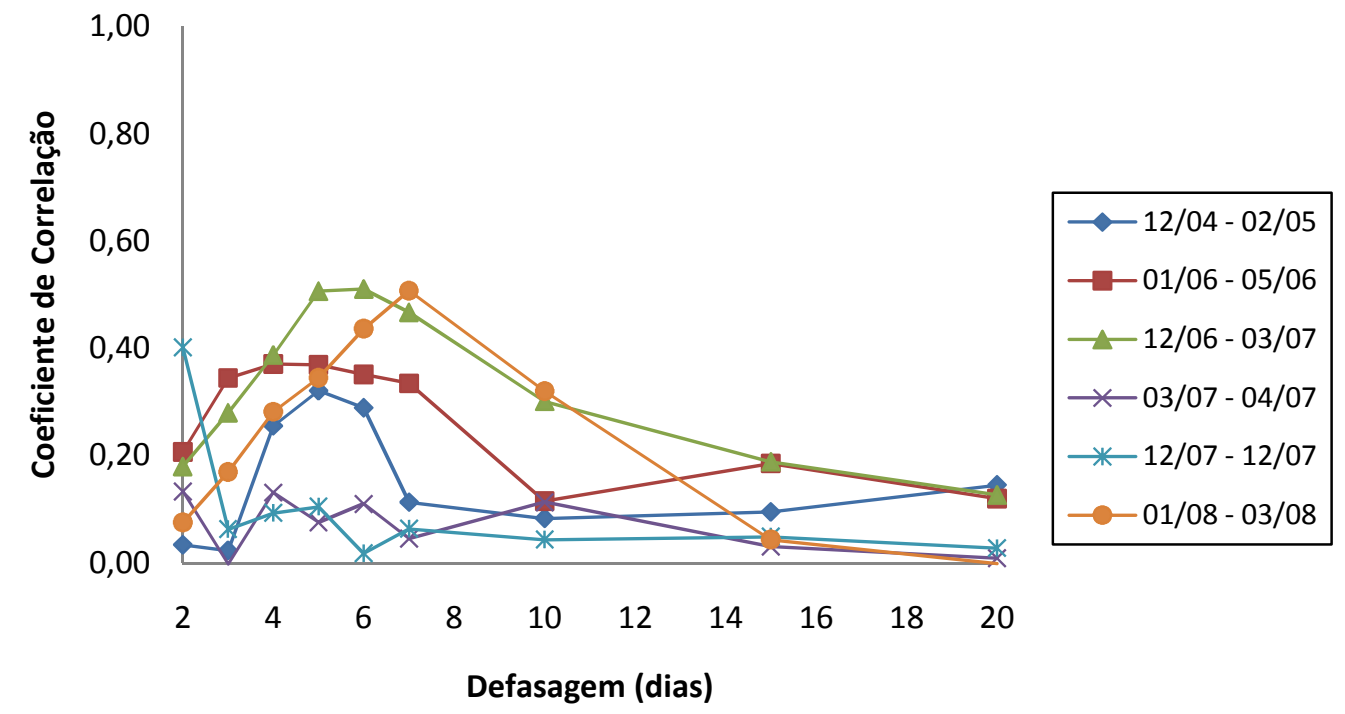

Figura 57: Coeficiente de correlação em função de diferentes defasagens de tempo para acumulação de precipitação anterior à elevação de nível no poço 18. 
No poço 19 ocorreram sete períodos de elevação do nível d'água. O primeiro deles ocorrido entre dezembro de 2004 e fevereiro de 2005, tendo duração de 60 dias, com variações diárias de $0,01 \mathrm{~m}$ e $0,11 \mathrm{~m}$. Os mais altos coeficientes foram resultaram de precipitações acumuladas de $7(\mathrm{r}=0,55), 10(\mathrm{r}=0,72), 15(\mathrm{r}=0,78)$ e $20(\mathrm{r}=0,58)$ dias. Nos meses de março (2005), dezembro (2006) e março (2007), abril (2007) e dezembro (2007) houve períodos de elevação do nível d'água, contudo os coeficientes de correlação não atingiram valores altos (acima de 0,4) para as precipitações acumuladas utilizadas. Em 2006, de março a maio, houve uma elevação do nível d'água de duração de 51dias, em que os coeficientes de correlação mais altos foram obtidos para as defasagens de 3 a 7 dias (0,6 a 0,7). Em 2008, entre janeiro e abril, durante 76 dias o nível d'água se elevou, e gerou coeficientes de correlação altos para precipitações de $5(\mathrm{r}=0,52), 6(\mathrm{r}=0,59)$ e $7(\mathrm{r}=0,59)$ dias. A figura 58 apresenta os valores de correlação obtidos para o poço 19.

Poço 19 - Pastagem ( 14,36 m)

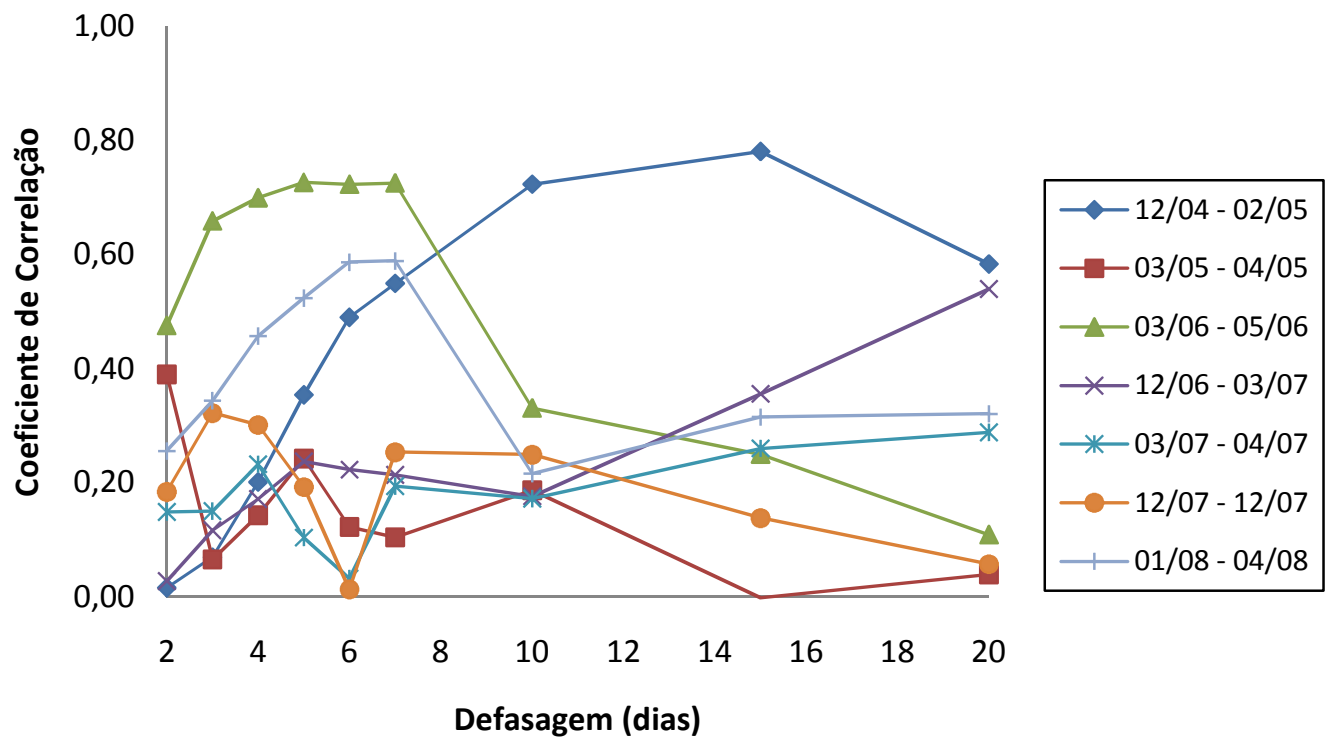

Figura 58: Coeficiente de correlação em função de diferentes defasagens de tempo para acumulação de precipitação anterior à elevação de nível no poço 19. 
A tabela 9 apresenta os mais elevados coeficientes de correlação obtidos, em função da defasagem.

Tabela 9: Resumo dos maiores coeficientes encontrados em relação a defasagem.

\begin{tabular}{r|l|r|r|r}
\hline \multicolumn{1}{c|}{ Poço } & Cultura & $\begin{array}{r}\text { Profundidade } \\
\text { média }(\mathrm{m})\end{array}$ & $\begin{array}{c}\text { Coeficiente } \\
\text { de Correlação }\end{array}$ & $\begin{array}{c}\text { Defasagem } \\
\text { (dias) }\end{array}$ \\
\hline 4 & Pastagem & 17,25 & 0,83 & 20 \\
5 & Pastagem & 6,54 & 0,91 & 15 \\
8 & Cana-de-açúcar & 22,68 & 0,91 & 15 \\
9 & Eucalipto & 21,58 & 0,3 & 04 \\
10 & Eucalipto & 20,29 & 0,38 & 10 \\
13 & Cítricos & 9,87 & 0,88 & 20 \\
14 & Cítricos & 6,69 & 0,84 & 15 \\
15 & Cítricos & 7,95 & 0,87 & 15 \\
16 & Pastagem & 5,08 & 0,78 & 15 \\
17 & Pastagem & 11 & 0,55 & 06 \\
18 & Pastagem & 13,68 & 0,55 & 06 \\
19 & Pastagem & 14,36 & 0,73 & 07 \\
\hline
\end{tabular}

Não foi possível definir um intervalo de tempo exato para o qual o coeficiente de correlação é mais alto para todos os poços. Porém, os resultados obtidos fornecem informações interessantes.

De maneira geral, o nível d'água nos poços responde melhor (maiores períodos de elevação) diante de séries de precipitação acumuladas mais longas (entre 10 e 20 dias antecedentes ao inicio da elevação do nível).

Quanto às diferentes culturas, não foi notado um padrão de comportamento no que diz respeito aos coeficientes de correlação. Esse resultado é explicado pelo fato do cálculo de correlação envolver apenas as séries de valores das variáveis estudadas. Para avaliar a correlação entre variação do nível d'água e outras características físicas da região, utilizadas nas outras etapas do trabalho, o ideal seria utilizar valores de outros fenômenos hidrológicos (taxas de infiltração e evapotranspiração), o que foge do escopo dessa pesquisa. 
Os poços 9 e 10, para todo o período estudado, geraram coeficientes de correlação muito baixos. O comportamento diferenciado das correlações nesses poços ocorreu pelo fato de que os níveis d'água começaram a elevar-se somente em 2007. Tais períodos de elevação são muito longos, quando comparados aos períodos de todos os outros poços. Era esperado que para tais períodos os coeficientes tivessem valores mais altos. Os resultados obtidos mostram a necessidade de estudar detalhadamente o papel das culturas de eucalipto nos processos de recarga de águas subterrâneas. 


\section{CONCLUSÕES E RECOMENDAÇÕES}

Este trabalho teve como objetivo definir uma relação direta entre os fenômenos de precipitação e de variação do nível d'água em aquífero livre, apoiado em dados de monitoramento hidrogeológico. Foram monitorados por quatro anos, dados de precipitação e profundidade do nível d'água em poços localizados na Bacia Piloto do Ribeirão da Onça.

No ano hidrológico de outubro de 2006 a setembro de 2007 ocorreu a maior altura pluviométrica, no valor de $1630 \mathrm{~mm}$. Há uma forte sazonalidade nas chuvas da região. No período de outubro a março ocorrem as taxas pluviométricas mais altas, enquanto que de abril a setembro ocorre o período de estiagem. Durante os anos analisados, a maior taxa detectada ocorreu no mês de janeiro de 2005 (542 mm), tal fato é explicado pelo adiantamento das chuvas ocorrentes no mês de fevereiro.

A série de dados de precipitação diária revelou que eventos de chuva são independentes, enquanto que a série de autocorrelação da precipitação mensal ratificou a existência de uma forte sazonalidade desse fenômeno hidrológico.

Foram analisados valores de monitoramento de 12 dos 23 poços instalados na Bacia Piloto do Ribeirão da Onça. Todos os níveis d'água nos poços monitorados acompanham a sazonalidade pluviométrica da área estudada, com exceção dos poços 9 e 10 cujos níveis d'água encontravam-se em declínio até 2007.

O estudo das autocorrelações das séries de dados referentes ao nível d'água nos poços mostrou uma forte dependência entre os dados coletados, bem como confirmou a existência de um padrão de sazonalidade.

Os agrupamentos gerados pelas técnicas hierárquicas mostraram a existência de cinco grupos de poços. Todas as características físicas escolhidas como atributo (porosidade, coeficiente de evapotranspiração e variação do nível d'água nos poços) 
foram de grande importância. As diferentes culturas cultivadas na região podem ser o fator que define o comportamento do nível d'água nos poços, visto o fato destes terem se agrupado de acordo com a cultura cultivada na área em que se localizam. Como a variação mensal dos níveis d'água nos poços foi utilizada para os cálculos de distância euclidiana, é possível afirmar que o coeficiente de evapotranspiração é o principal fator que influencia na variação dos níveis d'água subterrânea.

A porosidade também é um fator determinante no agrupamento dos poços. $\mathrm{O}$ poço 15 é o único localizado em área de porosidade igual a 8,5\%, e em todos os agrupamentos realizados não formou grupo com nenhum outro poço.

Os coeficientes de correlação mais elevados foram encontrados a partir da relação entre as variações diárias do nível d'água de poços localizados em área de mesma cultura. Isso significa que o coeficiente de evapotranspiração é fator fundamental para a movimentação do nível d'água subterrânea.

Os baixos coeficientes de correlação obtidos a partir da variação mensal do nível d'água no poço e da precipitação mensal acumulada mostram que não há uma reação imediata do nível d'água diante de um evento de precipitação. A utilização dos valores dessas variáveis em escalas logarítmicas resultou em coeficientes de correlação mais elevados (entre 0,3 e 0,6). Conclui-se que a relação entre as variáveis estudadas não é linear e, portanto, não é direta, existindo um período de defasagem entre os eventos.

A correlação entre a variação do nível d'água em períodos de elevação, corrigida pela porosidade da área onde o poço está localizado, e a precipitação acumulada para o período correspondente a essa elevação resultou em altos coeficientes. Os poços cujos níveis d'água atingem menores profundidades respondem mais rapidamente aos eventos de precipitação, caracterizando assim uma correlação linear entre as variáveis. Para níveis d'água mais profundos a correlação se mostra exponencial. 
Eventos isolados de precipitação não geram respostas imediatas (elevações) nos níveis d'água dos poços monitorados.

Os níveis d'água nos poços monitorados não respondem imediatamente aos eventos de precipitação. Os coeficientes mais elevados (acima de $r=0,5$ ) foram encontrados para precipitações acumuladas de 10,15 e 20 dias anteriores ao início da elevação do nível d'água nos poços. Em geral, os períodos de elevação do nível ocorrem por longos períodos de tempo (acima de 20 dias). No entanto, foi verificada a ocorrência de períodos curtos de elevação, sendo estes respostas as precipitações acumuladas ocorrentes no mesmo período. Para definir a correlação entre os fenômenos estudados é preciso considerar as precipitações acumuladas e somente os períodos em que ocorre elevação do nível d'água. Caso contrário, os valores de correlação serão baixos não condizendo com a realidade da situação.

A presente pesquisa se mostrou como importante ferramenta para o monitoramento dos processos de recarga de aquíferos, em especial o Sistema Aquífero Guarani, bem como para o planejamento do uso dos seus recursos hídricos. O estudo da influência da precipitação nesse sistema permite aprofundar os conhecimentos referentes ao balanço hídrico em regiões de afloramento.

Recomenda-se para estudos futuros o estudo da correlação entre a variação do nível d'água no aquiífero e outros fenômenos hidrológicos, principalmente a infiltração, uma vez que permitirá comparações com os resultados obtidos na presente pesquisa. Além disso, permitirá definir a existência de uma (ou mais) característica física da região que influencie de maneira mais significativa a variação do nível.

O estudo da influência das culturas cultivadas nas águas subterrâneas da região também é de grande valia. 
Quanto ao monitoramento hidrológico, faz-se necessário o estudo dos demais fenômenos que envolvem o balanço hídrico, permitindo o melhor e mais aprofundado entendimento do comportamento do processo de recarga na área de afloramento. Permite também definir de maneira precisa a relação entre fenômenos de precipitação, evapotranspiração e infiltração com as variações do nível d'água. O monitoramento contínuo desses fenômenos poderá gerar informações importantes para o melhor gerenciamento dos recursos hídricos subterrâneos. 


\section{REFERÊNCIAS BIBLIOGRÁFICAS}

ANDERSON, T.W. The Statistics Analysis of Time Series. John Wiley \& sons, INC. New Work. 1972.

BALEK, J. Groundwater recharge concepts. In: Simmers (ed.), Estimation of natural groundwater recharge. D. Reidel Publishing Company, Dordrecht, Holland. p.3-9.1988.

BARRETO, C.E.A.G. Balanço hídrico em zona de afloramento do sistema aquífero guarani a partir de monitoramento hidrogeológico em bacia representativa. Dissertação (Mestrado em Hidráulica e Saneamento). EESC-USP, São Carlos, SP.2006.

BORTOLUCCI, A. A. Caracterização Geológico-Geotécnica da região urbana de São Carlos-SP, a partir de sondagens de simples reconhecimento. Dissertação (Mestrado). Escola de Engenharia de São Carlos, Universidade de São Paulo, São Carlos, 1983.

BOX, G.E.P., JENKINS. G.M. Time Series Analysis: forecasting and control. Edição Revisada - New Jersey: Prentice Hall. 1994.

CONTIN NETO, D. Balanço hídrico em Bacia Hidrográfica situada em Região de Recarga do Aquíífero Guarani. Tese (Doutorado em Hidráulica e Saneamento). EESC-USP, São Carlos, SP. 1987.

CORRÊA, U. M. P. Estudo das Águas Subterrâneas das Bacias Hidrográficas dos Rios Jacaré-Guaçu e Jacaré-Pepira no Estado de São Paulo. Dissertação (Mestrado em Hidráulica e Saneamento). EESC-USP, São Carlos, SP. 1995.

CUNHA, A T. Estimativa experimental da taxa de recarga na zona de afloramento do Aqüífero Guarani, para a região de São Carlos - SP. Dissertação (Mestrado em Hidráulica e Saneamento). EESC-USP, São Carlos, SP. 2003.

CUSTODIO, E.; LlAMAS, M. R. Hidrología Subterránea. 2.ed., 2v. Barcelona: Omega, D.L. 1996.

DAVINO, A. Considerações Hidrogeológicas Preliminares sobre a Bacia Hidrográfica do Ribeirão da Onça, São Carlos, SP. Faculdade de Filosofia Ciências e Letras de Ribeirão Preto. Relatório apresentado a FAPESP. Página irregular. Ribeirão Preto. 1984.

DEMÉTRIO, C.G.B., ZOCCHI, S. S. Modelos de regressión aplicados a estudios en Edafologia. 1.ed. Guatemala. 2003.

DE VRIES, J. J.; SIMMERS, I. Groundwater recharge: an overview of processes and challenges. Hydrogeology Journal. 10:5-17. DOI 10.1007/s10040-001- 01717.2002 . 
DRAPPER, N.R.; SMITH. H. Applied regression analysis. 2ed.New York, Wiley e Sons. 508 p.1981.

EHLERS, R.S. Análise de Séries Temporais. Departamento de Estatística, UFPR.2005. Disponível em http://leg.est.ufpr.br/ ehlers/notas. Acesso em: 30 nov. 2007.

EVERITT, B.S., LANDAU, S., LEESE, M. Cluster Analysis. 4.ed. - London: Ed. Arnold. 2001.

FERRARO, F. Artigo de intercambio apresentado à Escola de Engenharia de São Carlos. 2006.

FETTER, C.W. Applied Hydrogeology. Macmillan: New York, 3rd ed. 1994.

GIAMPÁ, C. E. Q.; SOUZA, J. C. Potencial Aquiífero dos Basaltos da Formação Serra Geral no Estado de São Paulo. 2o CABAS, Salvador - BA. 1982.

GOMES, L.H. Determinação da recarga profunda na bacia piloto do ribeirão da onça em zona de afloramento do aqüífero guarani. Dissertação (Mestrado em Hidráulica e Saneamento). EESC-USP, São Carlos, SP. 2008.

GROPPO, J.D.; MORAES, J.M.; BEDUSCHI, C.E.; MARTINELLI, L.A. Análise de series temporais de vazão e precipitação em algumas bacias do estado de São Paulo com diferentes graus de intervenções antrópicas. Geociências. UNESP. São Paulo. V.24.181-193.2005.

JOBSON, J.D. Applied Multivariate Data Analysis, vol. 2:Categorical and Multivariate Methods. Springer-Veriag. 1992.

HEALY, R.W.; COOK, P.G. Using groundwater levels to estimate recharge. Hydrogeology Journal, 10. DOI 10.1007/s10040-001-0178-0. 2002.

LERNER, D.N.; BURSTON, M.W.; BISHOP, P.K. Hydrogeology of the Coventry region (UK): an urbanized, multi-layer dual-porosity aquifer system. Journal of Hydrology, 149 p.111-135. 1993.

MATTOS, I. S. Aplicação de um Modelo de Balanço Hídrico na Bacia do Rio Jacaré-Guaçu. Dissertação (Mestrado em Hidráulica e Saneamento). EESC-USP, São Carlos, SP. 1987.

MAYER, T.D.,CONGDON, R.D. Evaluating Climate Variability and Pumping Effects in Statistical Analyses. Ground Water 0(0).1-16. 2007.

MAZIERO, T.A. Monitoramento de água subterrânea em área urbana: aspectos quantitativos. Dissertação (Mestrado em Hidráulica e Saneamento). EESC-USP, São Carlos, SP. 2005. 
MEDEIROS, P.V. Análise da evapotranspiração de referência a partir de medidas lisimétricas e ajustes estatísticos de estimativas de nove equações empírico-teóricas com base na equação de Penman-Monteith. Dissertação (Mestrado em Hidráulica e Saneamento). EESC-USP, São Carlos, SP. 2008.

MILligAN, G.W.; COOPER, M.C. Methodology Review: Clustering Methods. Applied Psychological Measurement. v.11. 1987.

MOON, S.K., WOO, N.C., LEE, K.S. Statistical analysis of hydrographs and watertable fluctuation to estimate groundwater recharge. Journal of Hydrology (292).198209. 2004.

MORETTIN, P.A.; BUSSAB, W.O. Estatística Básica. 4.ed. São Paulo: Atual. 1987.

MORETTIN, P.A., TOLOI, C.M.C. Análise de Séries Temporais. 2.ed. São Paulo: Edgard Blucher. 2006.

MUÑOZ-DIAZ, D.; RODRIGO, F.S. Spatio-temporal patterns of seasonal rainfall in Spain (1912-2000) using cluster and principal component analysis: comparison. Annales Geophysicae, 22. 1435-1448. 2004.

MURRAY, A.T; VLADIMIR, E.C. Cluster Discovery techniques for exploratory spatial data analysis. Int. J. Geographical Information Science. v.12.nº5. 431443.1998 .

MYEONG-JAE Yi, KANG-KUN Lee. Transfer function-noise modeling of irregularly observed groundwater heads using precipitation data. Journal of Hydrology. 288: 272-287. 2004.

NAGHETTINI, M.; PINTO, E.J.A. Hidrologia Estatística. Belo Horizonte: CPRM. 2007.

PANDA, U. C.; SUNDARAY, S.K.; RATH, P.; NAYAK, B.B.; BHATTA, D. Application of factor and cluster analysis for characterization of river and estuarine water systems - A case study: Mahanadi River (India). Journal of Hidrology. 331. 434-445. 2006.

POMPÊO, C. A. Balanço Hídrico da Zona Não-Saturada do Solo na Bacia do Ribeirão da Onça (SP). Tese (Doutorado em Hidráulica e Saneamento). EESC-USP, São Carlos, SP. 1990.

RAMOS, F., OCCHIPINTI, A.G., VILLA NOVA, N.A., REICHARDT, K., MAGALHÃES, P.C., CLEARY, R.W. Engenharia Hidrológica. Coleção ABRH de Recursos Hídricos, Editora UFRJ, Rio de Janeiro. 1989. 
RAMOS, M. C. Divisive and hierarchical clustering techniques to analyze variability of rainfall distribution patterns in a Mediterranean region. Journal of Hydrology, New York, v: 57. 123-138. 2001.

RENNOLLS, K.; CARNELL, R.; TEE, V. A Descriptive Model of the Relationship Between Rainfall and Soil Water Table. Journal of Hydrology, New York: v. 47. v. 47.103-114.1980.

RUSHTON, K. R.; TOMLINSON, L. M. Possible mechanisms for leakage between aquifers and rivers. Journal of Hydrology, v.40. 49-65. 1979.

SANTOS, I.; FILL, H. D.; SUGAI, M. R. V. B.; BUBA, H.; KISHI, R. T.; MARONE, E.; LAUTERT, L. F. Hidrometria Aplicada. Curitiba: Instituto de Tecnologia para o Desenvolvimento. ISBN 85-88519-01-1.2001.

SPIELGEL, M.R. Estatística. Coleção Schaum, Editora McGraw-Hill do Brasil, Rio de Janeiro, 580 p.1970.

SYSTAT. Manual do Usuário.Versão 10. SPSS Science, USA. 2007.

TODD, D.K. Hidrologia de águas subterrâneas. Editora Edgard Blücher, Rio de Janeiro. 1959.

TUCCI, C.E.M. (organizador). Hidrologia: Ciência e Aplicação. 3.ed. Porto Alegre: Editora da UFRGS / ABRH. 2002.

VAN GEER, F.C.; ZUUR, A.F. An extension of Box-Jenkins transfer/noise models for spatial interpolation of groundwater head series. Journal of Hidrology.192.6580. 1996.

VEGA, M. et al. Assessment of seasonal and polluting effects on the quality of river water by exploratory data analysis. Water Research: v.32.3581-3592. 1998.

VIEIRA, S. Bioestatística: tópicos avançados. 2.ed. Rio de Janeiro: Elsevier. 2004.

VISWANATHAN, M.N. Recharge Characteristics of an Unconfined Aquifer from the Rainfall - Water Table Relationship. Journal of Hydrology, New York: v.70. 233-250. 1984.

WENDLAND, E.; BARRETO, C.; GOMES, L. H. Water balance in the Guarani Aquifer outcrop zone based on hydrogeologic monitoring. Journal of Hydrology .v. 342. 261-269. 2007.

ZHOU, Y. Sampling Frequency for Monitoring the Actual State of Groundwater Systems. Journal of Hydrology, v. 180. 301-318. 1996. 


\section{APÊNDICE A}

Profundidade Diária do Nível d'Água nos Poços Monitorados em função da Precipitação diária de chuva. 


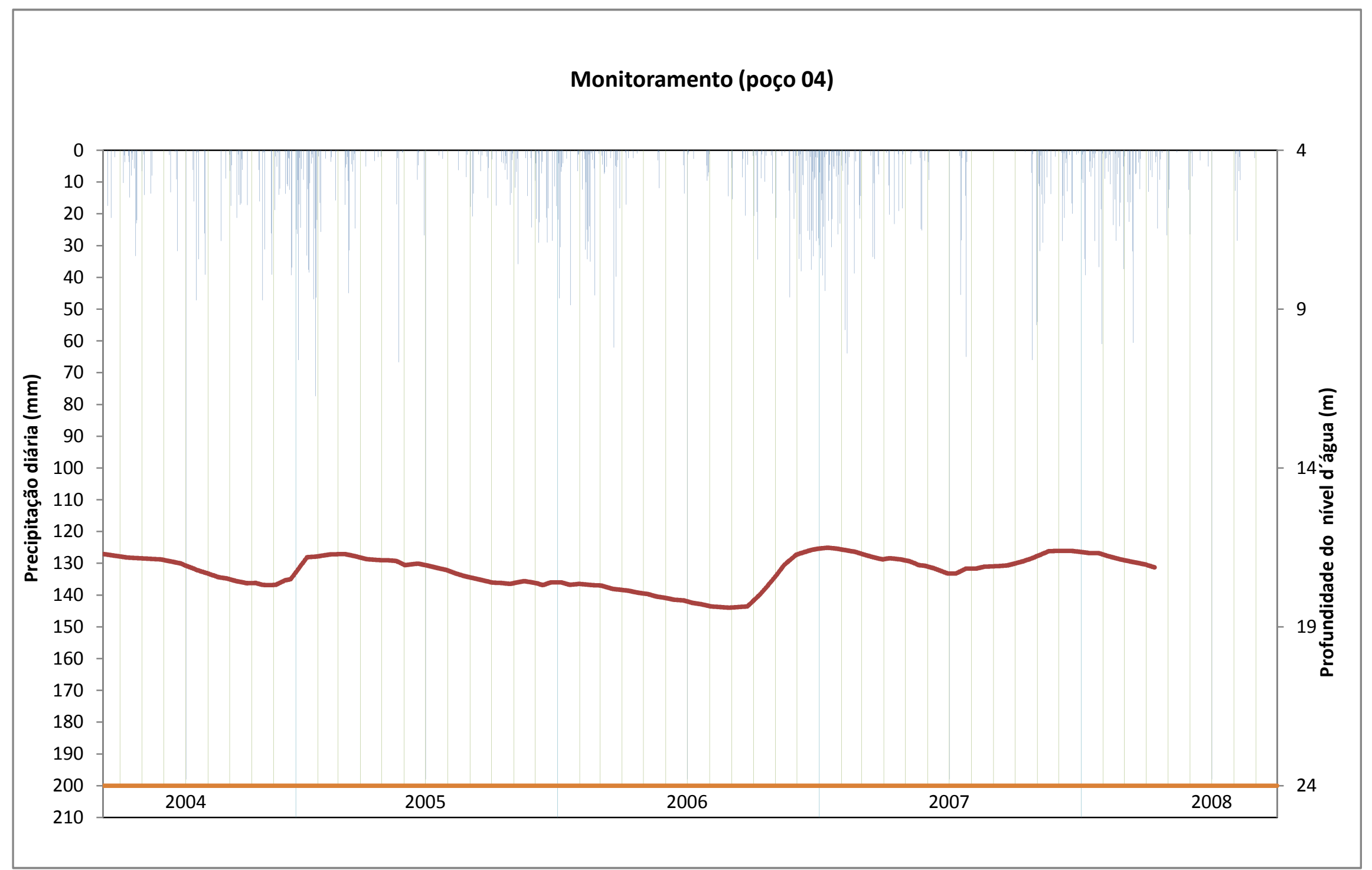




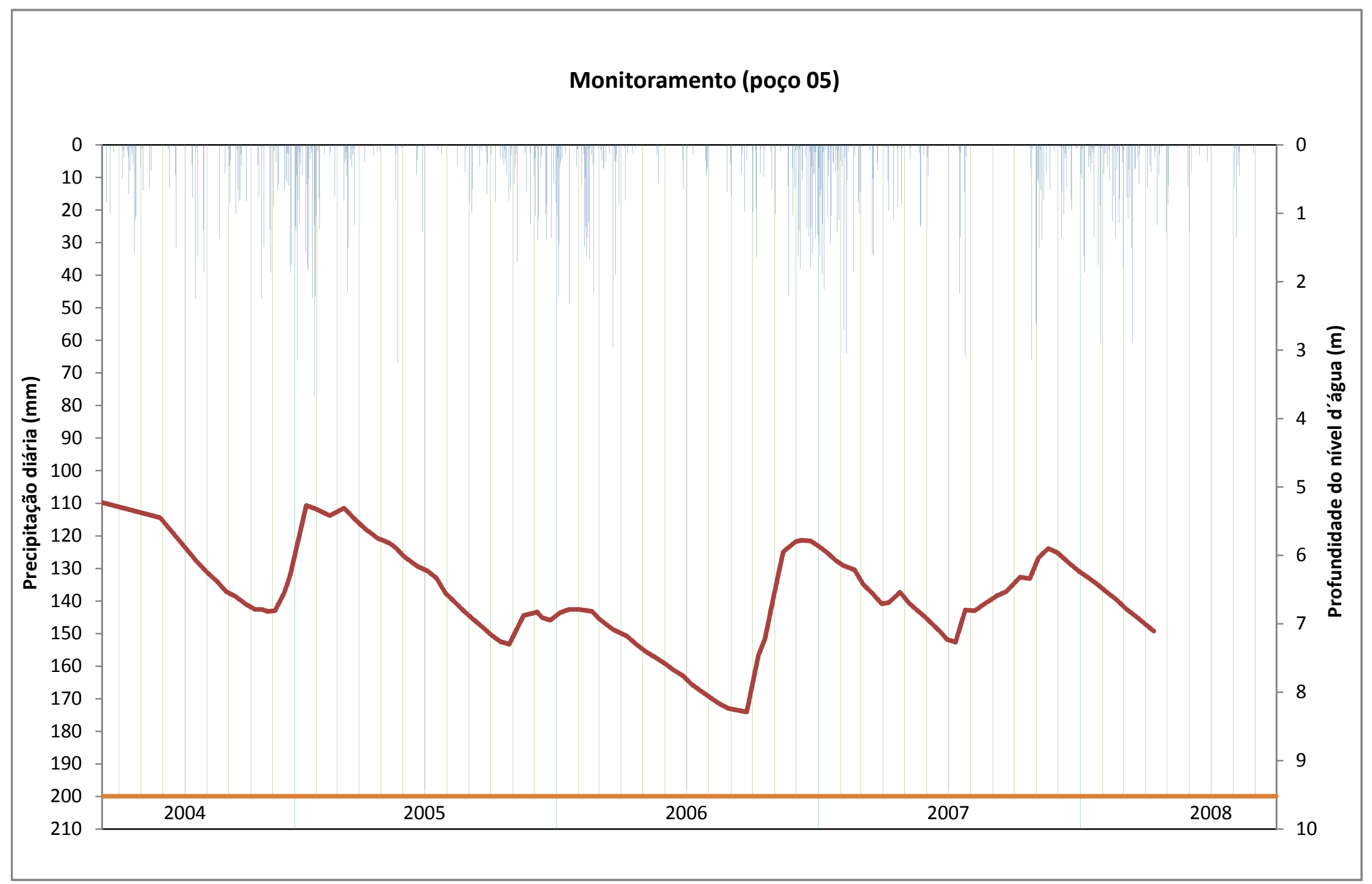




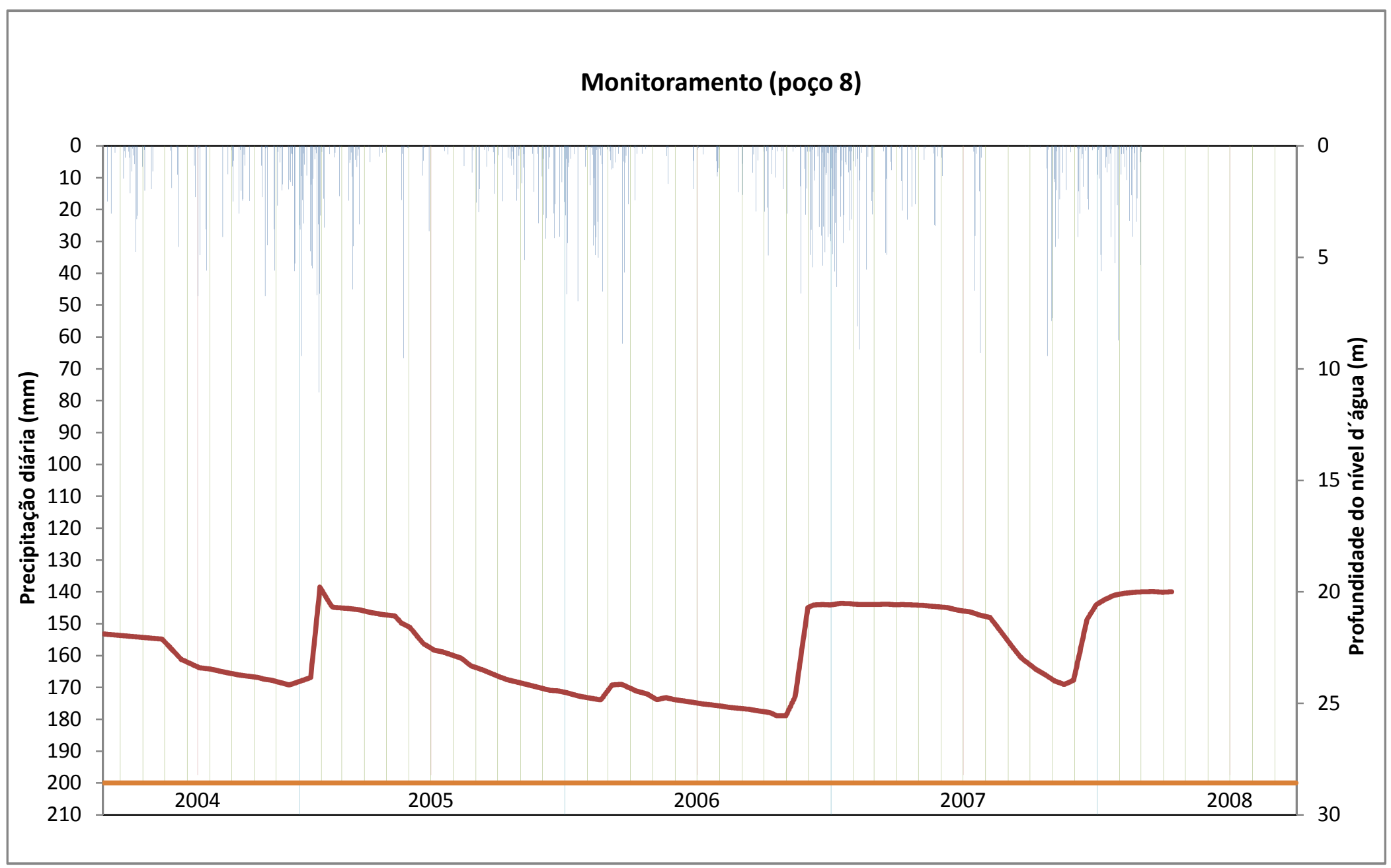




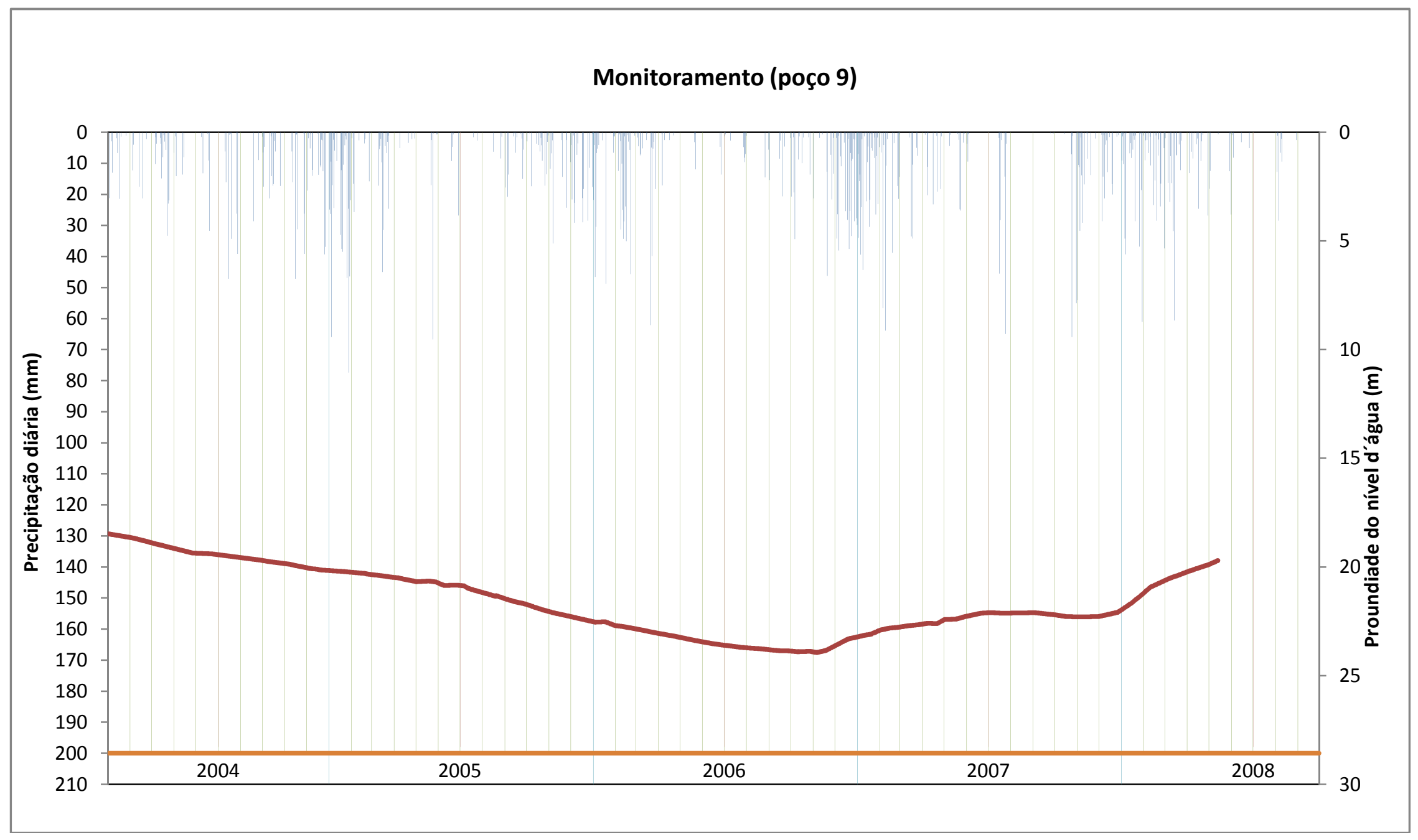




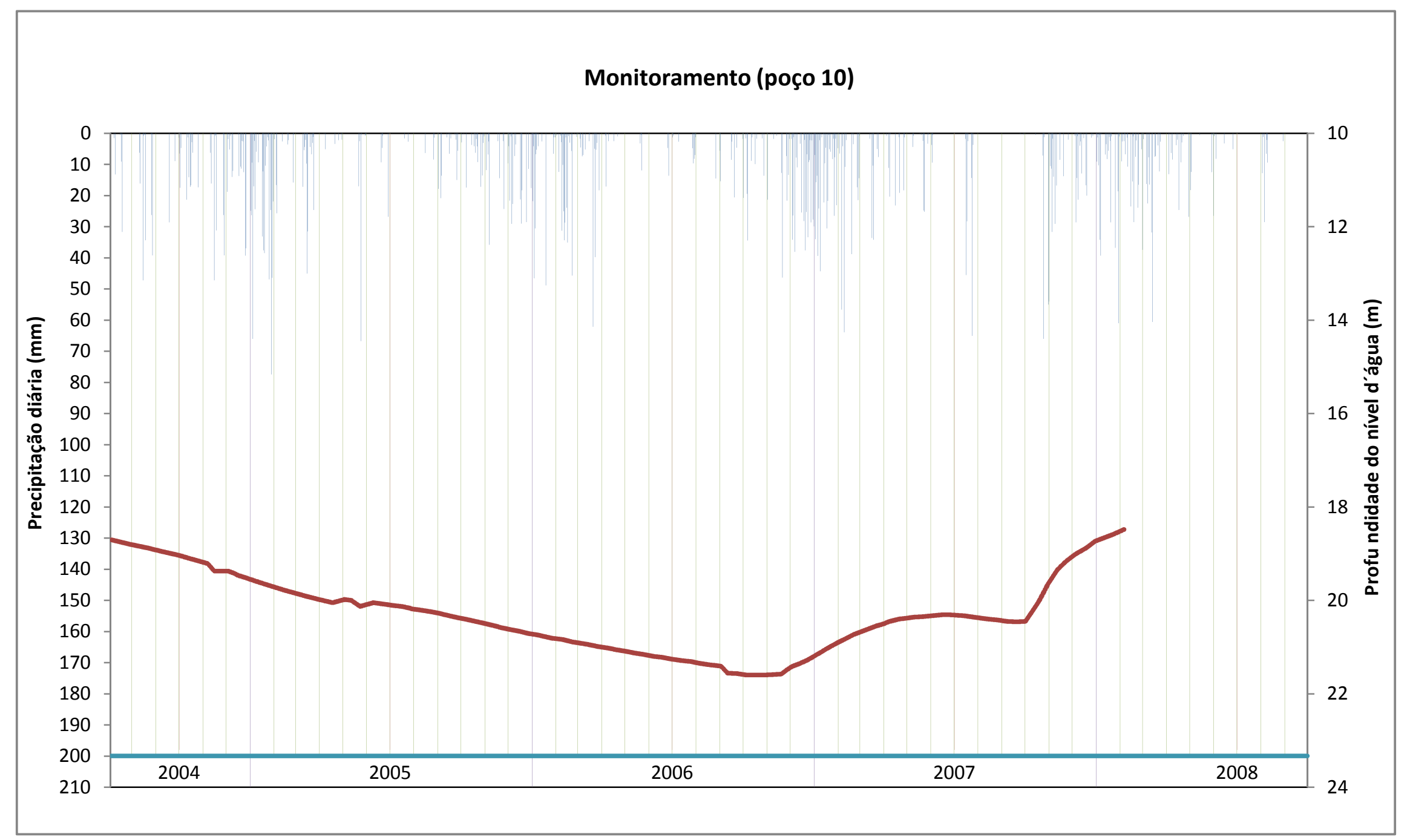




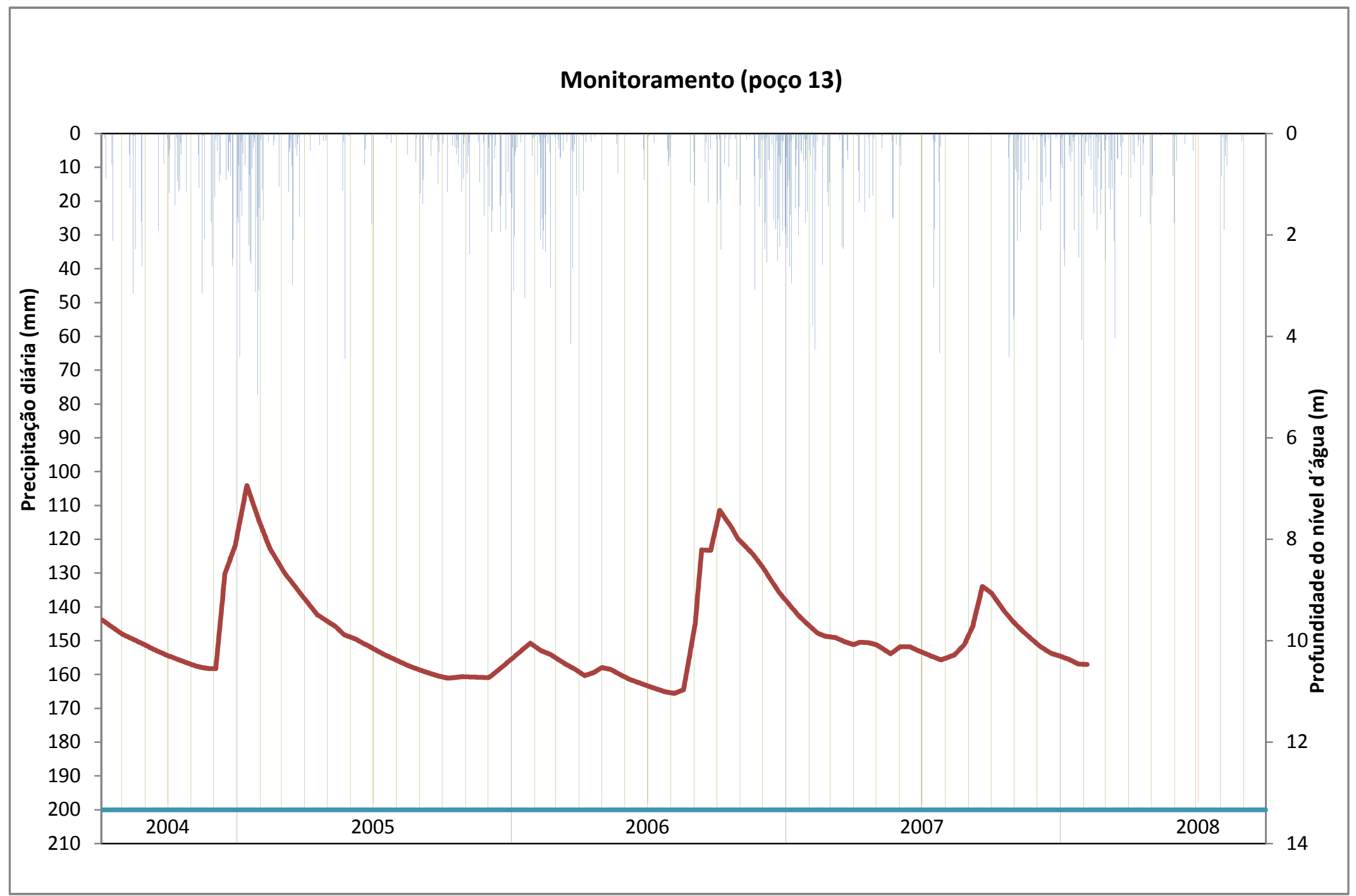




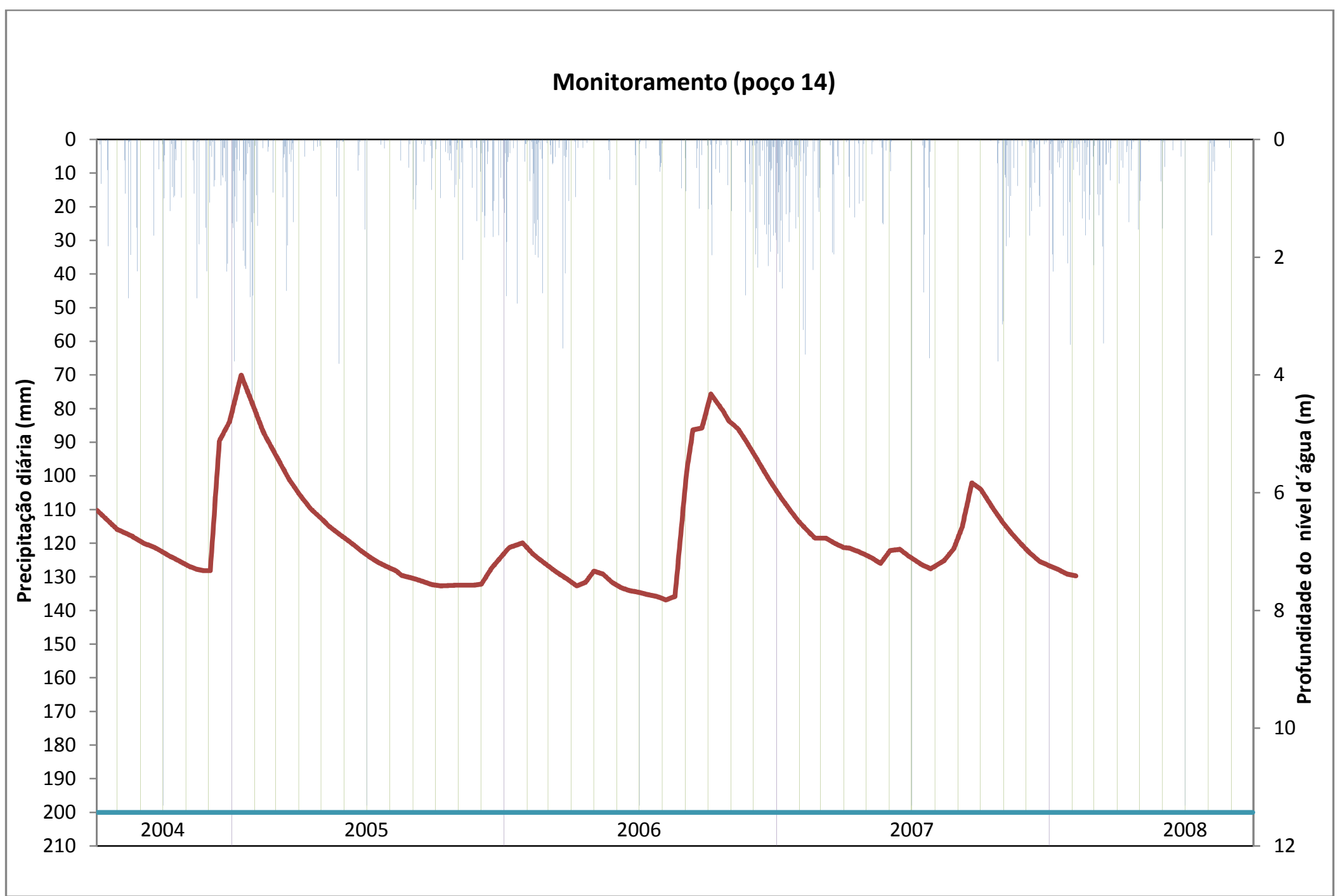









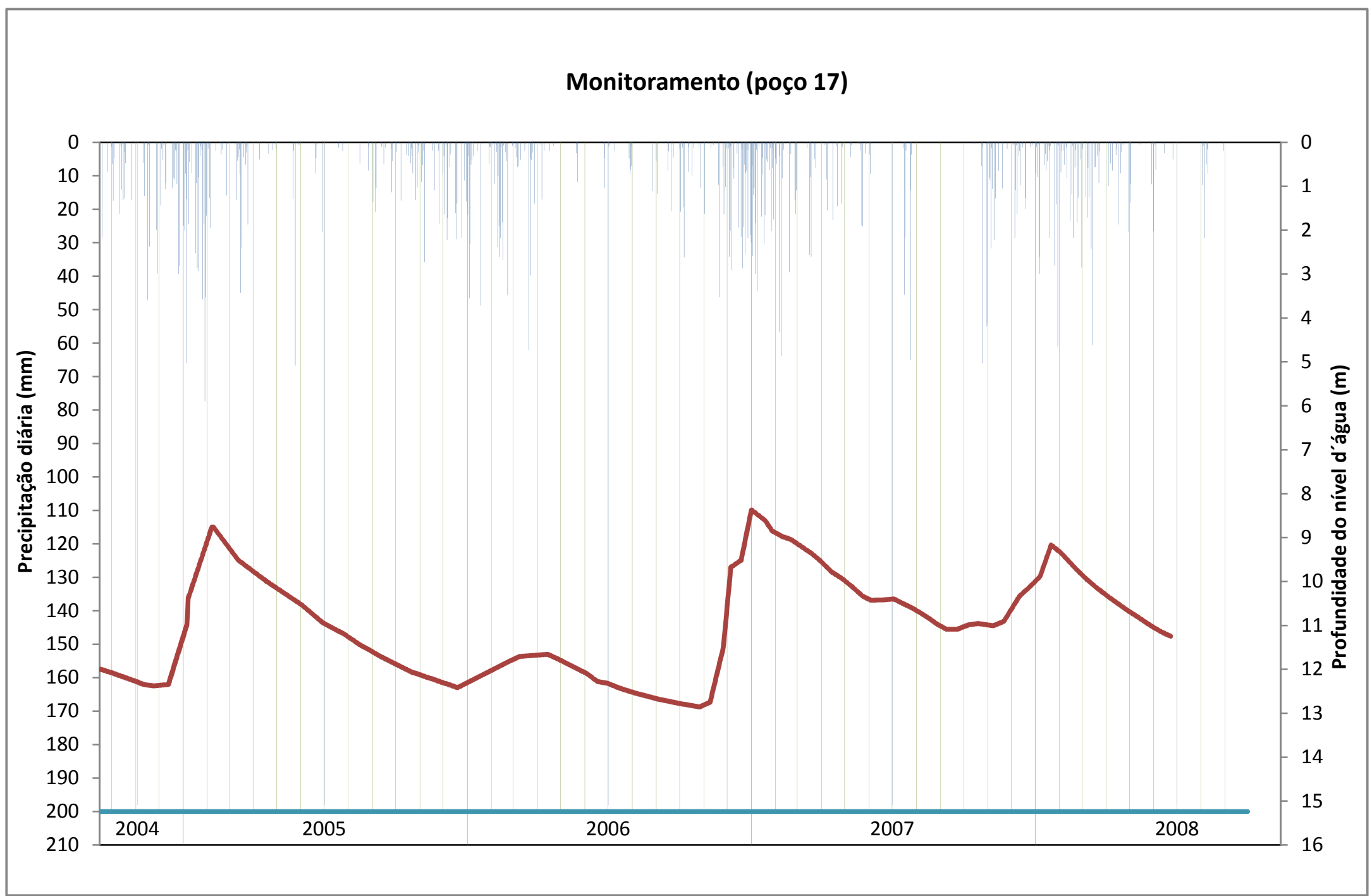




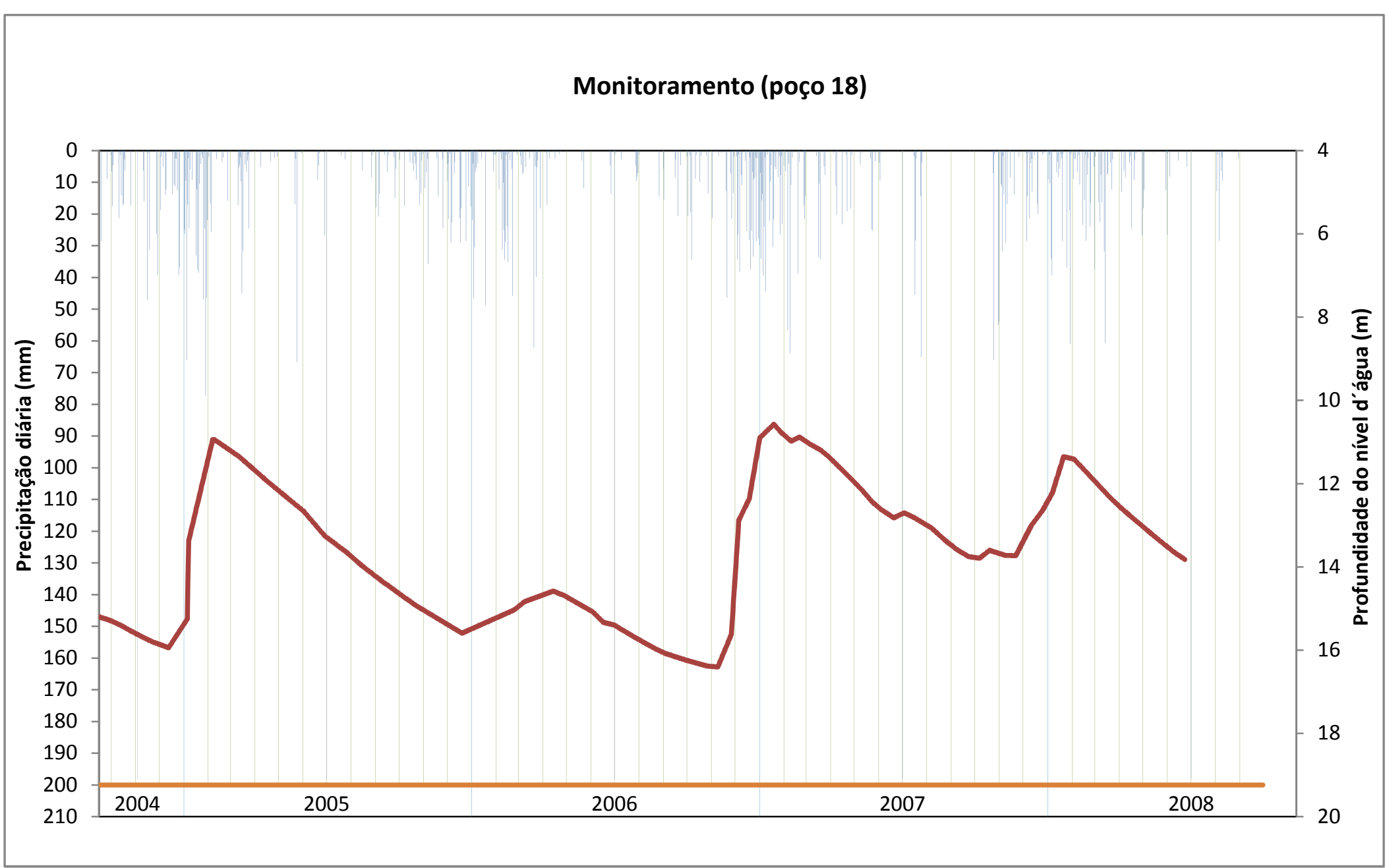




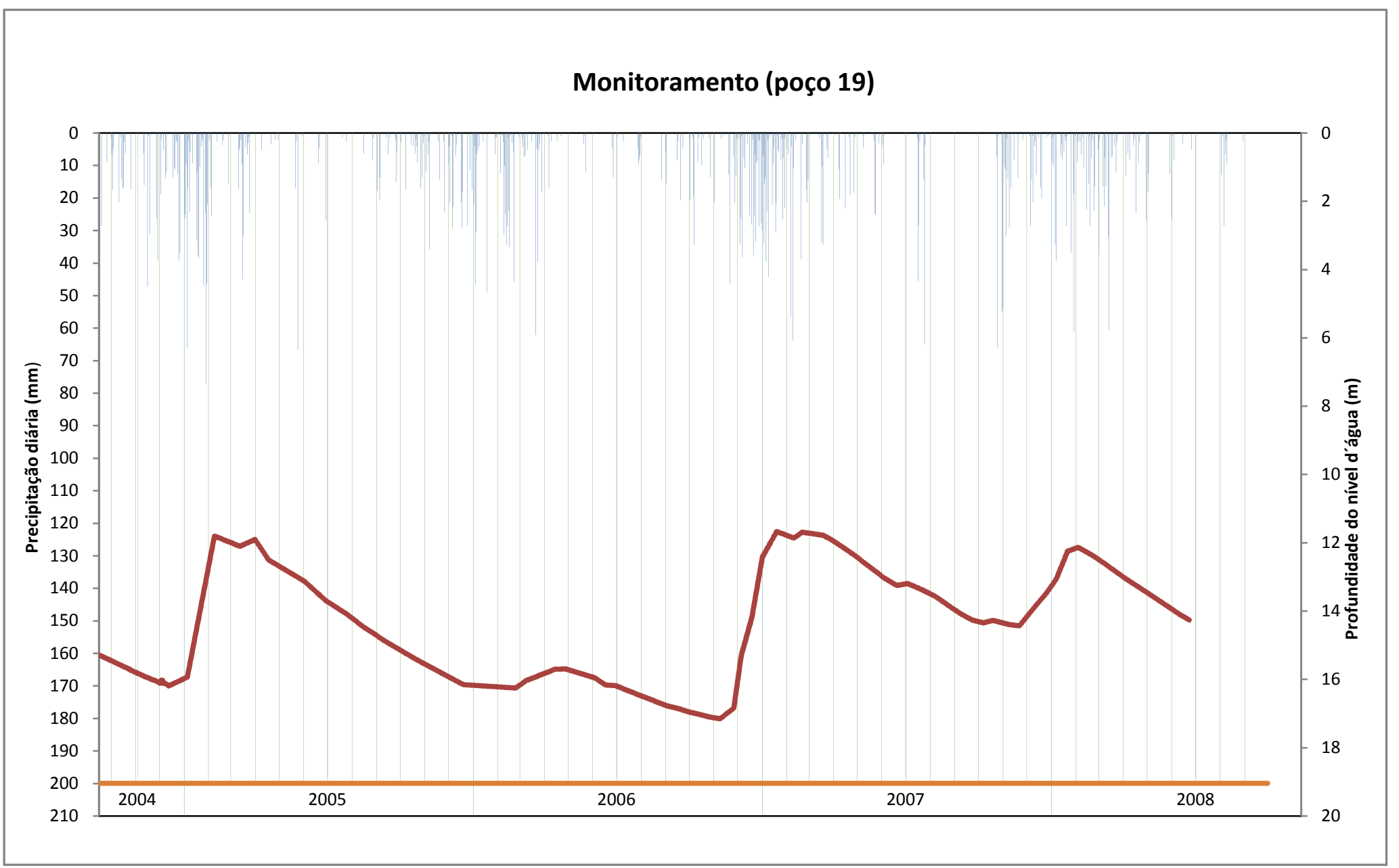


APÊNDICE B

Tabelas de medidas das alturas diárias das chuvas 
Tabela 10: Alturas Diárias de Chuva no período de Outubro de 2004 a Setembro de 2005.

\begin{tabular}{|c|c|c|c|c|c|c|c|c|c|c|c|c|}
\hline Dias & OUT & NOV & DEZ & JAN & FEV & MAR & ABR & MAI & JUN & JUL & AGO & SET \\
\hline 1 & 1,40 & 0,00 & 0,00 & 0,00 & 0,00 & 0,00 & 0,00 & 0,00 & 0,00 & 0,00 & 0,00 & 0,00 \\
\hline 2 & 6,50 & 0,00 & 0,00 & 24,90 & 1,90 & 0,00 & 0,00 & 0,00 & 0,00 & 0,00 & 0,00 & 17,80 \\
\hline 3 & 17,50 & 0,00 & 18,80 & 26,30 & 0,00 & 0,00 & 0,00 & 0,00 & 0,00 & 0,00 & 0,00 & 0,00 \\
\hline 4 & 4,70 & 0,00 & 1,90 & 9,40 & 16,60 & 0,00 & 0,00 & 0,00 & 0,00 & 0,00 & 0,00 & 0,00 \\
\hline 5 & 0,00 & 0,00 & 0,00 & 66,00 & 25,70 & 0,00 & 0,00 & 0,00 & 0,00 & 0,00 & 0,00 & 20,80 \\
\hline 6 & 0,00 & 0,00 & 5,20 & 17,00 & 0,00 & 0,00 & 0,00 & 0,00 & 0,00 & 0,00 & 0,00 & 13,60 \\
\hline 7 & 0,00 & 0,00 & 0,70 & 2,40 & 0,00 & 0,00 & 0,20 & 0,00 & 0,00 & 0,00 & 0,00 & 0,00 \\
\hline 8 & 0,00 & 0,00 & 0,00 & 24,40 & 0,00 & 0,00 & 0,00 & 0,00 & 0,00 & 0,00 & 0,00 & 0,00 \\
\hline 9 & 0,00 & 0,00 & 14,00 & 5,90 & 0,00 & 0,00 & 5,10 & 0,00 & 0,00 & 0,00 & 0,00 & 0,00 \\
\hline 10 & 0,00 & 0,00 & 12,10 & 0,00 & 0,00 & 0,00 & 0,00 & 0,00 & 0,00 & 0,00 & 0,00 & 0,00 \\
\hline 11 & 21,30 & 6,20 & 0,00 & 0,00 & 0,00 & 17,20 & 0,00 & 0,00 & 0,00 & 0,00 & 0,00 & 0,00 \\
\hline 12 & 0,00 & 16,10 & 0,00 & 9,30 & 2,60 & 5,40 & 0,00 & 0,00 & 0,00 & 0,00 & 0,00 & 0,00 \\
\hline 13 & 1,30 & 0,00 & 0,00 & 0,00 & 0,00 & 4,40 & 0,00 & 0,00 & 0,00 & 0,00 & 0,00 & 1,30 \\
\hline 14 & 14,10 & 0,00 & 0,00 & 0,00 & 0,00 & 2,10 & 0,00 & 0,00 & 0,00 & 0,00 & 0,00 & 0,00 \\
\hline 15 & 0,30 & 0,00 & 0,00 & 0,00 & 0,00 & 9,70 & 0,00 & 0,00 & 0,00 & 0,00 & 0,00 & 0,30 \\
\hline 16 & 17,20 & 47,20 & 0,00 & 0,00 & 0,00 & 45,00 & 0,00 & 0,00 & 0,00 & 0,00 & 6,30 & 6,60 \\
\hline 17 & 16,70 & 0,80 & 0,40 & 33,10 & 0,00 & 31,50 & 0,00 & 0,00 & 0,00 & 0,00 & 0,00 & 0,00 \\
\hline 18 & 2,80 & 0,50 & 13,70 & 12,20 & 0,20 & 0,00 & 0,00 & 0,00 & 0,00 & 0,00 & 0,00 & 1,60 \\
\hline 19 & 6,20 & 31,20 & 0,00 & 37,60 & 3,60 & 0,00 & 0,00 & 0,00 & 0,00 & 0,00 & 0,00 & 0,00 \\
\hline 20 & 0,00 & 0,00 & 10,70 & 38,50 & 2,20 & 4,40 & 0,00 & 0,00 & 9,30 & 1,60 & 0,00 & 0,00 \\
\hline 21 & 0,00 & 0,00 & 11,30 & 10,40 & 0,00 & 0,00 & 3,40 & 0,00 & 4,70 & 0,00 & 0,00 & 0,00 \\
\hline 22 & 0,00 & 0,00 & 2,40 & 0,00 & 0,00 & 6,70 & 0,00 & 17,00 & 0,70 & 0,00 & 0,00 & 0,00 \\
\hline 23 & 0,00 & 0,00 & 2,60 & 4,20 & 0,00 & 3,10 & 0,00 & 2,50 & 0,00 & 0,00 & 0,00 & 0,40 \\
\hline 24 & 0,00 & 0,00 & 12,50 & 1,20 & 0,00 & 1,10 & 0,00 & 0,00 & 0,00 & 0,00 & 0,00 & 0,00 \\
\hline 25 & 0,00 & 0,00 & 0,00 & 2,30 & 0,00 & 24,60 & 0,00 & 66,70 & 0,00 & 2,70 & 0,00 & 2,00 \\
\hline 26 & 17,30 & 0,00 & 39,30 & 46,90 & 15,80 & 0,00 & 2,20 & 0,40 & 0,00 & 0,00 & 0,00 & 15,00 \\
\hline 27 & 0,00 & 0,30 & 36,90 & 0,00 & 0,40 & 0,00 & 0,00 & 0,00 & 0,00 & 0,00 & 8,40 & 5,60 \\
\hline 28 & 0,00 & 26,20 & 0,00 & 24,60 & 0,00 & 0,00 & 0,00 & 0,00 & 0,00 & 0,00 & 1,40 & 0,00 \\
\hline 29 & 0,00 & 39,20 & 0,00 & 77,40 & - & 0,00 & 0,20 & 0,00 & 26,80 & 0,00 & 0,00 & 0,00 \\
\hline 30 & 0,00 & 0,00 & 0,00 & 46,40 & - & 0,00 & 2,00 & 0,70 & 0,00 & 0,00 & 0,00 & 0,00 \\
\hline 31 & 0,00 & - & 0,00 & 21,90 & - & 0,00 & - & 0,60 & - & 0,00 & 0,00 & - \\
\hline
\end{tabular}


Tabela 11: Alturas Diárias de Chuvas no período de Outubro de 2005 a Setembro de 2006.

\begin{tabular}{|c|c|c|c|c|c|c|c|c|c|c|c|c|}
\hline Dias & OUT & NOV & DEZ & JAN & FEV & MAR & ABR & MAI & JUN & JUL & AGO & SET \\
\hline 1 & 0,00 & 0,00 & 9,60 & 0,50 & 0,00 & 0,00 & 0,00 & 0,00 & 0,00 & 0,00 & 1,2 & 5,6 \\
\hline 2 & 2,90 & 0,00 & 4,10 & 21,80 & 0,70 & 0,30 & 0,00 & 0,00 & 0,00 & 1,30 & 0,0 & 15,4 \\
\hline 3 & 0,00 & 11,80 & 21,60 & 4,10 & 0,00 & 0,00 & 0,00 & 0,00 & 0,00 & 0,70 & 0,0 & 0,0 \\
\hline 4 & 0,00 & 0,00 & 0,00 & 46,60 & 0,00 & 1,70 & 0,00 & 0,00 & 0,00 & 0,00 & 0,0 & 0,0 \\
\hline 5 & 0,30 & 6,80 & 1,00 & 30,50 & 12,40 & 4,50 & 0,00 & 0,00 & 0,00 & 0,00 & 0,0 & 0,0 \\
\hline 6 & 0,00 & 2,60 & 29,10 & 6,70 & 0,00 & 0,00 & 0,70 & 0,00 & 0,00 & 0,00 & 0,0 & 0,0 \\
\hline 7 & 0,00 & 35,80 & 22,70 & 5,30 & 0,70 & 7,40 & 17,10 & 0,00 & 0,00 & 0,00 & 0,0 & 0,0 \\
\hline 8 & 17,40 & 0,00 & 0,00 & 0,20 & 2,80 & 7,00 & 0,20 & 0,00 & 0,00 & 0,00 & 0,0 & 0,0 \\
\hline 9 & 0,00 & 0,00 & 0,00 & 4,10 & 31,30 & 0,00 & 0,00 & 0,00 & 0,00 & 0,00 & 0,0 & 0,0 \\
\hline 10 & 0,00 & 0,00 & 7,30 & 0,00 & 10,10 & 0,00 & 2,50 & 0,00 & 0,00 & 2,70 & 0,0 & 0,0 \\
\hline 11 & 0,00 & 0,00 & 3,60 & 0,00 & 25,00 & 5,20 & 0,00 & 0,00 & 0,00 & 0,00 & 0,0 & 0,0 \\
\hline 12 & 0,00 & 0,00 & 0,00 & 0,00 & 34,30 & 0,00 & 0,00 & 0,00 & 0,00 & 0,00 & 0,0 & 0,0 \\
\hline 13 & 0,00 & 0,00 & 0,00 & 0,00 & 28,70 & 0,00 & 0,00 & 0,00 & 0,00 & 0,00 & 0,0 & 0,0 \\
\hline 14 & 0,00 & 0,00 & 0,00 & 2,60 & 1,30 & 0,00 & 0,00 & 0,00 & 0,00 & 0,00 & 0,0 & 0,0 \\
\hline 15 & 3,70 & 0,00 & 0,00 & 0,00 & 23,90 & 0,00 & 0,20 & 0,00 & 0,00 & 0,00 & 0,0 & 0,0 \\
\hline 16 & 0,00 & 0,00 & 0,00 & 0,00 & 35,10 & 2,50 & 0,00 & 0,00 & 0,00 & 0,00 & 0,0 & 8,5 \\
\hline 17 & 0,00 & 0,00 & 21,20 & 0,00 & 0,90 & 0,40 & 2,50 & 0,00 & 0,00 & 0,00 & 0,0 & 2,7 \\
\hline 18 & 4,10 & 2,50 & 29,00 & 0,00 & 0,00 & 0,00 & 0,00 & 0,00 & 0,00 & 0,00 & 0,0 & 0,0 \\
\hline 19 & 0,20 & 0,00 & 18,30 & 48,80 & 3,00 & 0,00 & 0,00 & 0,00 & 0,00 & 0,00 & 0,0 & 0,0 \\
\hline 20 & 6,20 & 14,40 & 0,00 & 0,00 & 0,00 & 0,00 & 0,00 & 0,00 & 0,00 & 0,00 & 0,0 & 20,6 \\
\hline 21 & 1,80 & 0,00 & 0,00 & 0,00 & 5,70 & 62,10 & 0,00 & 3,20 & 0,00 & 0,00 & 0,0 & 0,0 \\
\hline 22 & 4,20 & 0,00 & 0,00 & 0,00 & 45,70 & 0,00 & 1,00 & 0,60 & 0,00 & 0,00 & 0,0 & 0,0 \\
\hline 23 & 9,20 & 0,00 & 0,00 & 0,00 & 0,00 & 4,90 & 0,00 & 11,90 & 0,00 & 0,00 & 0,0 & 4,6 \\
\hline 24 & 0,00 & 0,00 & 0,00 & 0,00 & 0,00 & 39,80 & 0,20 & 0,00 & 0,00 & 0,00 & 0,0 & 0,0 \\
\hline 25 & 0,00 & 2,50 & 28,50 & 0,30 & 0,30 & 5,30 & 0,00 & 0,00 & 0,00 & 0,00 & 0,0 & 0,0 \\
\hline 26 & 0,00 & 24,30 & 0,00 & 0,00 & 0,00 & 3,10 & 0,00 & 0,00 & 4,70 & 0,00 & 0,0 & 0,0 \\
\hline 27 & 17,20 & 0,00 & 0,00 & 0,00 & 0,00 & 0,00 & 0,00 & 0,00 & 13,60 & 0,00 & 14,5 & 0,0 \\
\hline 28 & 0,00 & 0,00 & 11,40 & 0,00 & 1,10 & 0,00 & 0,00 & 0,00 & 0,00 & 4,80 & 0,0 & 0,0 \\
\hline 29 & 13,50 & 0,00 & 0,00 & 6,60 & - & 18,30 & 0,00 & 0,00 & 0,00 & 9,60 & 0,0 & 0,0 \\
\hline 30 & 3,10 & 0,00 & 0,00 & 1,30 & - & 0,00 & 0,00 & 0,00 & 0,00 & 8,20 & 0,0 & 0,0 \\
\hline 31 & 1,00 & - & 17,60 & 1,30 & - & 0,00 & - & 0,00 & - & 7,00 & 0,0 & - \\
\hline
\end{tabular}


Tabela 12: Alturas Diárias de Chuva no período de Outubro de 2006 a Setembro de 2007.

\begin{tabular}{|c|c|c|c|c|c|c|c|c|c|c|c|c|}
\hline Dias & OUT & NOV & DEZ & JAN & FEV & MAR & ABR & MAI & JUN & JUL & AGO & SET \\
\hline 1 & 1,8 & 0,0 & 0,0 & 29,9 & 4,8 & 0,7 & 0,0 & 0,0 & 0,0 & 0,0 & 0,0 & 0,0 \\
\hline 2 & 20,7 & 21,3 & 0,0 & 7,0 & 0,3 & 0,0 & 0,0 & 0,0 & 3,7 & 0,0 & 0,0 & 0,0 \\
\hline 3 & 0,0 & 0,0 & 1,8 & 34,0 & 6,5 & 0,0 & 0,0 & 0,0 & 9,4 & 0,0 & 0,0 & 0,0 \\
\hline 4 & 0,0 & 0,0 & 34,2 & 15,7 & 0,0 & 0,0 & 0,0 & 0,0 & 0,6 & 0,0 & 0,0 & 0,0 \\
\hline 5 & 1,6 & 0,0 & 26,4 & 13,6 & 0,0 & 0,0 & 0,8 & 0,0 & 0,0 & 0,0 & 0,0 & 0,0 \\
\hline 6 & 19,4 & 0,0 & 1,2 & 39,4 & 56,6 & 0,0 & 0,0 & 0,0 & 0,0 & 0,0 & 0,0 & 0,0 \\
\hline 7 & 34,4 & 0,3 & 38,1 & 24,1 & 4,1 & 0,0 & 0,0 & 0,0 & 0,0 & 0,0 & 0,0 & 0,0 \\
\hline 8 & 0,0 & 0,0 & 0,0 & 2,2 & 0,0 & 0,0 & 11,1 & 0,0 & 0,0 & 0,0 & 0,0 & 0,0 \\
\hline 9 & 0,0 & 0,0 & 7,8 & 44,3 & 63,9 & 0,0 & 20,3 & 4,4 & 0,0 & 0,0 & 0,0 & 0,0 \\
\hline 10 & 0,0 & 1,8 & 10,9 & 0,0 & 10,8 & 0,0 & 0,3 & 0,8 & 0,0 & 0,0 & 0,0 & 0,0 \\
\hline 11 & 0,0 & 0,0 & 0,0 & 1,3 & 0,0 & 0,0 & 0,0 & 0,0 & 0,0 & 0,0 & 0,0 & 0,0 \\
\hline 12 & 8,8 & 0,0 & 0,0 & 0,0 & 2,2 & 0,0 & 0,0 & 0,0 & 0,0 & 0,0 & 0,0 & 0,0 \\
\hline 13 & 1,3 & 0,0 & 0,0 & 0,3 & 0,0 & 0,0 & 0,0 & 0,0 & 0,0 & 0,0 & 0,0 & 0,0 \\
\hline 14 & 0,3 & 0,7 & 3,3 & 22,2 & 0,0 & 1,7 & 0,0 & 0,0 & 0,0 & 0,0 & 0,0 & 0,0 \\
\hline 15 & 0,0 & 0,0 & 0,3 & 9,6 & 0,0 & 0,0 & 0,0 & 0,0 & 0,0 & 0,0 & 0,0 & 0,0 \\
\hline 16 & 0,0 & 0,0 & 25,4 & 4,6 & 0,0 & 0,0 & 23,2 & 0,0 & 0,0 & 1,8 & 0,0 & 0,0 \\
\hline 17 & 9,9 & 0,0 & 0,0 & 0,0 & 0,0 & 33,6 & 0,0 & 0,0 & 0,0 & 45,5 & 0,0 & 0,0 \\
\hline 18 & 0,0 & 0,0 & 0,4 & 30,5 & 0,0 & 10,4 & 0,0 & 0,2 & 0,0 & 28,3 & 0,0 & 0,0 \\
\hline 19 & 1,7 & 0,0 & 28,2 & 21,7 & 38,8 & 34,2 & 0,0 & 0,0 & 0,0 & 2,5 & 0,0 & 0,0 \\
\hline 20 & 0,0 & 12,7 & 2,1 & 0,6 & 0,2 & 0,0 & 0,0 & 0,5 & 0,0 & 0,0 & 0,0 & 0,0 \\
\hline 21 & 0,0 & 46,3 & 37,6 & 5,1 & 3,5 & 0,0 & 1,2 & 0,0 & 0,0 & 0,0 & 0,0 & 0,0 \\
\hline 22 & 0,0 & 0,0 & 25,3 & 5,9 & 0,0 & 0,0 & 19,1 & 2,4 & 0,0 & 0,0 & 0,0 & 0,0 \\
\hline 23 & 0,0 & 0,0 & 6,7 & 0,3 & 0,0 & 0,0 & 0,0 & 24,8 & 0,0 & 0,3 & 0,0 & 0,0 \\
\hline 24 & 0,0 & 0,0 & 33,4 & 0,0 & 0,0 & 5,0 & 0,0 & 25,2 & 0,0 & 14,3 & 0,0 & 0,0 \\
\hline 25 & 0,0 & 0,0 & 9,2 & 8,3 & 0,0 & 7,6 & 0,0 & 0,0 & 0,0 & 65,0 & 0,0 & 0,3 \\
\hline 26 & 1,6 & 7,3 & 8,6 & 1,7 & 17,3 & 0,0 & 0,0 & 0,0 & 0,0 & 3,7 & 0,0 & 0,0 \\
\hline 27 & 0,0 & 21,6 & 2,2 & 26,5 & 21,5 & 0,0 & 18,3 & 0,0 & 0,0 & 0,0 & 0,0 & 0,0 \\
\hline 28 & 13,6 & 0,0 & 28,6 & 7,7 & 14,4 & 0,0 & 1,3 & 3,3 & 0,0 & 0,0 & 0,0 & 0,0 \\
\hline 29 & 0,0 & 13,4 & 2,3 & 1,7 & - & 0,0 & 0,0 & 0,4 & 0,0 & 0,0 & 0,0 & 0,4 \\
\hline 30 & 0,0 & 1,8 & 0,0 & 23,1 & - & 0,0 & 0,0 & 0,0 & 0,0 & 0,0 & 0,0 & 0,0 \\
\hline 31 & 0,0 & - & 27,7 & 0,0 & - & 0,0 & - & 0,0 & - & 0,0 & 0,0 & - \\
\hline
\end{tabular}


Tabela 13: Alturas Diárias de Chuvas no período de Outubro de 2007 a Setembro de 2008.

\begin{tabular}{|c|c|c|c|c|c|c|c|c|c|c|c|c|}
\hline Dias & OUT & $\mathrm{NOV}$ & DEZ & JAN & FEV & MAR & ABR & MAI & JUN & JUL & AGO & SET \\
\hline 1 & 0,0 & 54,0 & 0,0 & 0,2 & 0,0 & 37,4 & 0,0 & 0,0 & 26,5 & 0,0 & 0,0 & 0,0 \\
\hline 2 & 0,0 & 0,3 & 0,0 & 9,1 & 0,0 & 1,9 & 0,0 & 18,2 & 0,9 & 0,0 & 0,0 & 0,0 \\
\hline 3 & 0,0 & 10,5 & 0,0 & 1,3 & 9,0 & 0,0 & 0,0 & 12,4 & 0,0 & 0,0 & 12,8 & 0,0 \\
\hline 4 & 0,0 & 11,3 & 0,0 & 10,3 & 2,6 & 0,0 & 13,1 & 0,0 & 8,2 & 0,0 & 1,1 & 0,0 \\
\hline 5 & 0,0 & 31,7 & 0,8 & 0,6 & 0,0 & 0,0 & 0,1 & 0,0 & 0,0 & 0,0 & 0,0 & 0,0 \\
\hline 6 & 0,0 & 1,7 & 28,6 & 34,2 & 2,5 & 16,3 & 0,0 & 0,0 & 0,0 & 0,0 & 28,5 & 0,0 \\
\hline 7 & 0,0 & 13,9 & 14,3 & 39,3 & 0,3 & 0,0 & 6,3 & 0,0 & 0,0 & 0,0 & 0,0 & 0,5 \\
\hline 8 & 0,0 & 0,0 & 0,9 & 0,3 & 6,7 & 22,5 & 0,0 & 0,0 & 0,0 & 0,0 & 6,6 & 0,4 \\
\hline 9 & 0,0 & 29,1 & 21,3 & 0,0 & 0,0 & 7,7 & 8,4 & 0,0 & 0,0 & 0,0 & 2,1 & 2,7 \\
\hline 10 & 0,0 & 0,0 & 0,0 & 0,0 & 1,4 & 16,4 & 0,0 & 0,0 & 0,0 & 0,0 & 9,4 & 0,0 \\
\hline 11 & 0,0 & 16,8 & 4,0 & 0,0 & 10,7 & 0,0 & 0,3 & 0,0 & 0,0 & 0,0 & 0,0 & 0,6 \\
\hline 12 & 0,0 & 0,0 & 2,6 & 0,0 & 0,0 & 0,0 & 0,0 & 0,0 & 0,0 & 0,0 & 0,0 & 0,0 \\
\hline 13 & 0,0 & 0,0 & 12,9 & 6,8 & 0,0 & 31,8 & 0,0 & 0,0 & 0,0 & 0,0 & 0,0 & 0,0 \\
\hline 14 & 0,0 & 0,3 & 0,0 & 3,5 & 0,0 & 60,6 & 3,8 & 0,6 & 0,0 & 0,0 & 0,0 & 8,3 \\
\hline 15 & 0,5 & 8,5 & 0,0 & 8,3 & 23,5 & 0,0 & 2,0 & 0,0 & 3,2 & 0,0 & 0,0 & 0,0 \\
\hline 16 & 0,0 & 0,3 & 1,5 & 0,0 & 0,0 & 0,0 & 0,0 & 0,0 & 0,0 & 0,0 & 0,0 & 0,0 \\
\hline 17 & 0,0 & 0,0 & 0,0 & 5,6 & 15,5 & 7,5 & 24,6 & 0,0 & 0,0 & 0,0 & 0,0 & 0,0 \\
\hline 18 & 0,0 & 0,0 & 0,0 & 1,1 & 1,0 & 7,3 & 0,0 & 0,0 & 0,0 & 0,0 & 0,0 & 0,0 \\
\hline 19 & 0,0 & 0,0 & 16,7 & 2,4 & 28,5 & 0,0 & 0,0 & 0,0 & 0,0 & 0,0 & 0,0 & 0,0 \\
\hline 20 & 0,0 & 13,8 & 20,0 & 28,6 & 0,0 & 0,0 & 9,3 & 0,0 & 0,0 & 0,0 & 0,0 & 0,0 \\
\hline 21 & 0,0 & 0,0 & 0,0 & 1,0 & 7,5 & 3,9 & 2,9 & 0,0 & 0,0 & 0,0 & 0,0 & 15,5 \\
\hline 22 & 0,0 & 0,0 & 0,0 & 0,0 & 2,3 & 0,2 & 0,0 & 0,0 & 0,0 & 0,0 & 0,0 & 1,7 \\
\hline 23 & 0,0 & 0,0 & 0,0 & 0,0 & 0,0 & 12,2 & 0,8 & 0,0 & 0,0 & 0,0 & 0,0 & 0,0 \\
\hline 24 & 7,1 & 0,0 & 0,0 & 0,0 & 23,9 & 2,7 & 0,0 & 0,0 & 0,0 & 0,0 & 0,0 & 0,0 \\
\hline 25 & 66,0 & 0,0 & 0,0 & 0,0 & 16,5 & 0,0 & 0,0 & 0,0 & 0,0 & 0,0 & 0,0 & 0,0 \\
\hline 26 & 1,2 & 2,0 & 1,4 & 36,8 & 0,0 & 0,0 & 0,0 & 0,0 & 5,1 & 0,0 & 0,0 & 8,8 \\
\hline 27 & 0,0 & 0,0 & 0,0 & 0,0 & 0,0 & 0,0 & 0,0 & 0,0 & 0,0 & 0,0 & 0,0 & 0,0 \\
\hline 28 & 0,0 & 0,0 & 0,9 & 0,4 & 0,0 & 0,0 & 0,0 & 0,0 & 0,0 & 0,0 & 0,0 & 0,0 \\
\hline 29 & 0,0 & 0,0 & 0,0 & 18,6 & 5,1 & 0,0 & 0,2 & 0,0 & 0,0 & 0,0 & 0,0 & 0,0 \\
\hline 30 & 0,0 & 0,0 & 0,0 & 61,0 & - & 0,0 & 26,8 & 12,5 & 0,0 & 0,0 & 2,5 & 0,0 \\
\hline 31 & 55,0 & - & 0,0 & 1,0 & - & 0,0 & - & 0,4 & - & 0,0 & 0,0 & - \\
\hline
\end{tabular}


